\title{
Vascular endothelial cells in immune reactions
}

Citation for published version (APA):

Groenewegen, G. (1985). Vascular endothelial cells in immune reactions. [Doctoral Thesis, Maastricht University]. Rijksuniversiteit Limburg. https://doi.org/10.26481/dis.19850621gg

Document status and date:

Published: 01/01/1985

DOI:

10.26481/dis.19850621gg

Document Version:

Publisher's PDF, also known as Version of record

\section{Please check the document version of this publication:}

- A submitted manuscript is the version of the article upon submission and before peer-review. There can be important differences between the submitted version and the official published version of record.

People interested in the research are advised to contact the author for the final version of the publication, or visit the DOI to the publisher's website.

- The final author version and the galley proof are versions of the publication after peer review.

- The final published version features the final layout of the paper including the volume, issue and page numbers.

Link to publication

\footnotetext{
General rights rights.

- You may freely distribute the URL identifying the publication in the public portal. please follow below link for the End User Agreement:

www.umlib.nl/taverne-license

Take down policy

If you believe that this document breaches copyright please contact us at:

repository@maastrichtuniversity.nl

providing details and we will investigate your claim.
}

Copyright and moral rights for the publications made accessible in the public portal are retained by the authors and/or other copyright owners and it is a condition of accessing publications that users recognise and abide by the legal requirements associated with these

- Users may download and print one copy of any publication from the public portal for the purpose of private study or research.

- You may not further distribute the material or use it for any profit-making activity or commercial gain

If the publication is distributed under the terms of Article $25 \mathrm{fa}$ of the Dutch Copyright Act, indicated by the "Taverne" license above, 
Vascular endothelial cells in immune reactions 
Drukkerij Groenevelt b.v. - Landgraaf 


\section{Vascular endothelial cells in immune reactions}

\section{Proefschrift}

ter verkrijging van de graad van doctor in de geneeskunde aan de Rijksuniversiteit Limburg te Maastricht, op gezag van Rector Magnificus, Prof. Dr. F.I.M. Bonke, volgens het besluit van het College van Dekanen, in het openbaar te verdedigen op vrijdag 21 juni 1985 om vier uur

door

Gerard Groenewegen

geboren te Eindhoven. 
Promotor

: Prof. Dr. G. Kootstra

Co-promotor : Dr. W.A. Buurman

Referenten : Prof. Dr. J.A. Flendrig

Dr. C.J.M. Melief

Prof. Dr. P.J. Morris

Publikatie van dit proefschrift werd financieel ondersteund door Nier Stichting Nederland en Sandoz b.v., Uden. 
Voor hersenvoedsel wordt dat misschien wat te vel, mak er mar anderhalf ons van.

S. Vestdink 


\section{CONTENTS}

CHAPTER 1

Introduction

Essence of immune reactions

Targets of immune reactions

Events in immune reactions

CHAPTER 2

Introduction to the experiments

Literature cited

CHAPTER 3

Cellular cytotoxicity against canine endothelial cells.

21 Analysis of determinants recognized by CTL
Summary
Introduction
Results
Discussion
Literature cited

Materials and methods

CHAPTER 4

Cell-mediated cytotoxicity patterns of cloned cytotoxic $T$ lymphocytes. Cytotoxicity directed against canine lymphoblasts, monocytes and endothelial cells

Summary

Introduction

Materials and Methods

Results

Discussion

Literature cited

CHAPTER 5

Lymphokines induce change in morphology and 45 enhance motility of endothelial cells

Summary

Introduction

Materials and methods

Results

Discussion

Literature cited 

thelial cells. A study with canine arterial and venous endothelial cells

Summary

Introduction

Materials and methods

Results

Discussion

Literature cited

\section{CHAPTER 7}

CHAPTER 8

CHAPTER 9

CHAPTER 10

Vascular endothelial cells present alloantigens to unprimed lymphocytes

Summary
Introduction
Materials and methods
Results
Discussion
Literature cited

Self-alloantigen presentation by canine endothelial cells in vitro

Summary

Introduction

Materials and methods

Results

Discussion

Literature cited

Cyclosporin A affects MHC-class II antigen expres83 sion by arterial and venous endothelium in vitro

Summary

Introduction

Materials and methods

Results

Discussion

Literature cited

In vitro expression of $\mathrm{MHC}$-class II antigens by endo93 thelium is lymphokine dependend

Summary

Demonstration

Literature cited 
CHAPTER 11

General discussion of the experiments

Literature cited

CHAPTER 12A Summary

HOOFDSTUK 12 B Samenvatting

List of publications

Acknowledgements

112

Curriculum witae

113 



\section{Introduction}

Transplantation of allogeneic kidneys is an accepted mode of treatment for end stage chronic renal failure. The maximal achievable one year graft survival appears to be approximately $80 \%(1,2)$. Loss of an allograft can be attributed to 1) reactions of the recipient against the donor organ, 2) to factors related to insufficient quality of the transplanted kidney which can be explained by circumstances during procurement and preservation, 3) to recurrence of kidney disease, and 4) to technical factors. Only the first mentioned cause of graft loss will be considered here.

The immune system discriminates between self and non-self. The immunological nature of the reactions of the recipient leading to rejection of the donor organ has been demonstrated (3). An essential role of T-lymphocytes in these reactions is accepted (4). The aim of this study is to determine in immune reactions which result in rejection of transplanted organs the role and function of endothelial cells, the cells that form the interface between recipient and vascularized allograft.

\section{Essence of immune reactions}

The immunological reactions against an allograft can be divided in a humoral and in a cellular part. Humoral immunological reactions, in which antibodies are involved, can damage a graft via complement dependent cytotoxicity and via antibody dependent cellular cytotoxicity. In the first, binding of complement, a set of protein compounds of body fluids acting in sequence, by an immune complex, eg antibody bound to an allografted cell, results in activation of the cascade of complement factors. Such an activation of complement factors can result in lysis of the cell to which the complement factors are bound via the immune complexes. In the second type of humoral reactions, antibody binds specifically to a cell of the graft and nonspecific to an effector cell of antibody dependent cellular cytotoxicity, upon which the transplanted cell is lysed by the effector cell (monocytes and $\mathrm{NK} / \mathrm{K}$-cells).

The cellular part of the immunological reactions against an allograft can be divided in delayed-type hypersensitivity (DTH), cell-mediated cytotoxicity (CMC) and NK cell reactivity. Delayed type hypersensitivity reactions result in the release of soluble mediators by $\mathrm{T}$ lymphocytes. Such mediators can have a detrimental effect on the function of an allograft. Cell-mediated cytotoxicity results in the generation of cytotoxic $\mathrm{T}$ lymphocytes (CTL). CTL recognize antigens on the allografted cells via an antigen specific receptor. Binding of CTL to cells carrying the specific determinant recognized by the CTL results in lysis of the antigen bearing cell. NK-cells recognize, via a mechanism poorly understood, target cells aspecifically, which are then lyzed. 
Apart from these brieflly mentioned reaction types, other not yet defined mechanisms cannot be exciuded.

\section{Targets of immune reactions}

The strongest immune reactions in allograft rejection can be attributed to the Major Histocompatibility Complex (MHC). The MHC can be divided in MHC-class I and MHC-class II antigens. These antigens are of major importance in the discrimination by the immune system between self and non-self. MHC-class I antigens are considered to be the target determinants of CTL and have a regular task in immune reactions against viruses (5), while MHC-class II antigens are assumed to be involved in delayed type hypersensitivity reactions and in immunoregulation (6).

Matching of MHC-class I and MHC-class II antigens has a benificial effect on prolongation of graft survival. The effect of MHC-class II antigens appears however to be stronger $(7,8)$. Though MHC-antigens have a major influence on the outcome of an allograft, other antigens have an effect as well (9). Steinmuller and colleagues demonstrated an alloantigen specific for epidermal cells in the mouse $(10,11,12)$. The involvement of this antigen in rejection of murine skin allografts has been demonstrated (13). Canine kidney epithelial cells carry tissue specific antigens recognized by CTL $(14,15)$. Also for heart, liver and pancreas similar antigens have been described (16). An antigen present only on monocytes and vascular endothelial cells has been described (17). The role of an endothelial antigen in rejection of renal allografts has been suggested (18-20). So far endothelial antigens have only been detected serologically $(16,21)$. Other, non-MHC-antigens on monocytes have been described (22-25), which can be present on some others cells as well.

\section{Events in immune reactions}

Activation of $\mathrm{T}$ lymphocytes occurs on contact between lymphocytes and antigen presenting cells (APC), which express MHC-class II antigens and the presented antigen on their cell surface (6). MHC-class II antigens guide the process of antigen presentation as signal in intercellular communication. For only a limited number of cell types the antigen presenting capacity has been demonstrated. Among these cells are the bone-marrow derived monocytes/macrophages, dendritic cells including Langerhans cells of the skin, B lymphocytes and non bone-marrow derived cells like Kupfer cells of the liver and vascular endothelial cells (26-33). The contact of lymphocytes with antigen and antigen presenting cells results in release of interleukin 1. (Il-1) by the antigen presenting cells. Il- $\mathbb{L}$ is the activation signal for $\mathrm{T}$ lymphocytes (34). At this stage of the reaction a subdivision of the cellular immunological reactions can be made. One subset of $T$ lymphocytes, $T$ helper cells, produces interleukin 2 (Il-2) which serves as growth factor for the subset of cytotoxic $T$ lymphocytes which obtain Il-2-receptors during activation. Besides 11-2, other soluble mediators, lymphokines, are produced by the $\mathrm{T}$ helper subset, which modulate the behaviour 
of a large array of cells involved in immune reactions. The complete spectrum of different lymphokines and their effects is incompletely understood. It is known that attraction of monocytes to sites of lymphokine release is caused by macrophage chemotactic factor. After migration the monocytes are kept at that site by migration inhibition factor. Monocytes are activated for lysis of intracellular organisms by macrophage activating factor, a lymphokine identical to interferon-gamma (IFN- $\gamma$ ) (35). IFN- $\gamma$ is capable of induction of increased MHC-class II antigen expression on monocytes and other cells $(36,37)$. Since $T$ helper cells are restricted to MHCclass II antigens for their activation, secretion of the lymphokine IFN results in amplification of the response. The production of II-2 facilitates the expansion of II-2 dependent activated cytotoxic $T$ lymphocytes. Recognition of the antigen by the sensitized CTL on a cell surface via the antigen receptor results in lysis of the antigen bearing cells. CTL have a function in elimination of virally infected cells (5) and recognize MHC-class I antigens of a virus infected cell together with viral antigens. In an allograft, CTL recognize allo-MHC-class I antigens, which can be considered as altered self, like infected cells. Recently, the described concepts of cellular immune reactions were challenged. The existence of helper independent cytotoxic $\mathrm{T}$ lymphocyte clones was demonstrated, a type of CTL that produces its own growth factor I1-2 in response to antigen (38). Also, T lymphocytes with the surface-marker phenotype of $T$ helper lymphocytes, had the functional phenotype of cytotoxic $T$ lymphocytes (39). These CTL recognize MHC-class II antigens for lysis of target cells $(40,41)$. Besides MHC-antigens, non-MHC-antigens, such as the Epa-antigen on epidermal cells, can serve as target for CTL during graft rejection (13). Humoral immune reactions are related to cellular cytotoxicity reactions. Help of $T$ helper cells, activated by antigen on MHC-class II antigen expressing antigen presenting cells, results in activation of B-lymphocytes. Proliferation and differentiation of B lymphocytes directed via T helper produced B cell growth factor, Il-2 (42) and $B$ cell differentiation or maturation factor, lead to production of plasma cells, which secrete antibody. 



\section{CHAPTER 2}

\section{Introduction to the experiments}

The aim of the experimental work was to clarify the functions of endothelial cells in rejection of allografts. The function of endothelial cells in different parts of the immunological process leading to rejection of allografts was studied. In vitro systems have been designed to allow study of separate events in the chain of consecutive events in immunological reactions. The dog was used as laboratory animal. Endothelial cells were obtained from arteries or veins, respectively referred to as arterial endothelial cells (AEC) and venous endothelial cells (VEC). The cells were released from vessel walls by collagenase-digestion and were kept in culture (43). In culture, endothelial cell population expanded by proliferation of the cells. Culture procedures and identification procedures for canine AEC and VEC have been described in chapter 3 .

Endothelial cells were tested for their capacity to be lysed by CTL, generated in mixed lymphocyte culture (MLC) $(44,45)$. The target determinants recognized on AEC and VEC by CTL were compared with the target determinants recognized on lymphoblasts, the often used target cell to detect cell-mediated cytotoxicity. Results of these experiments, presented in chapter 3, indicated that endothelial cells can be lysed by CTL and that AEC and VEC were recognized by different target determinants, compared to lymphoblasts. The fine specificities of CTL have been studied at the clonal level, as presented in chapter 4. CTL, generated in MLC were cloned with a limiting dilution technique, based on exogenous growth factor I1-2. This technique has been proven useful in the in vitro canine experimental system (46). Cloned CTL were tested for their capacity to lyse lymphoblasts, monocytes, AEC and VEC and were grouped in patterns of lysis of one or more than one of these four different target cells. The results indicated that a limited number of patterns of $\mathrm{CMC}$ against. these four target cells existed. This finding suggested that different alloantigenic systems were detected, with limited distribution of the antigens over the target cells. Lymphokines, as part of the delayed type hypersensitivity reactions, in vitro released into the supernatant of MLC, were studied for their effects on morphology and motility of venous endothelial cells. The effect of supernatants containing only one lymphokine was analysed similarly. The ability of canine endothelial cells to be af fected by human lymphokines was tested, as was the effect of canine lymphokines on human umbilical vein endothelial cells. The effects of lymphokines, described in chapter 5, were induction of change in morphology and enhancement of motility of endothelial cells. Lymphokines acted in a speciesspecific system only; $11-2$ and IFN- $\gamma$ did not have an effect.

The capacity of endothelial cells to activate allogeneic lymphocytes was studied in chapter 6. Proliferation of lymphocytes was assayed, including optimal lymphocyte- 
endothelial cell ratio and kinetics of the response. The generated CTL were studied for their capacity to lyse AEC, VEC and lymphoblasts. Both AEC and VEC were used in mixed lymphocyte endothelial cell cultures. AEC and VEC stimulated proliferation of allogeneic lymphocytes. AEC generated CTL against AEC and lymphoblasts. Stimulation with VEC resulted in CTL which lysed VEC, lymphoblasts and also AEC.

An initial event in immunological reactions is antigen-presentation. In the process of allograft rejection these antigens are named alloantigens. To study the capacity of endothelial cells to present alloantigens, a system of antigen-presenting cell depleted mixed lymphocyte cultures was used. In chapter 7 the capacity of endothelial cells to present alloantigens to syngeneic unprimed lymphocytes has been described. It appeared that both AEC and VEC have this capacity of alloantigen presentation. A different form of alloantigen presentation to lymphocytes of the recipient in a process called self-alloantigen presentation has been studied in chapter 8 . In allograft rejection, a cell of donor origin presents its own alloantigen to lymphocyte of the recipient in a process called self-alloantigen presentation. Mixed lymphocyte endothelial cell cultures of antigen-presenting cell depleted lymphocytes were used to study the self-alloantigen presenting capacity of venous endothelial cells. The data show that endothelial cells have this capacity in vitro.

The expression of $\mathrm{MHC}$-class II antigens, involved in regulation of immunological reactions, was studied in chapter 9 and 10 , for respectively the in vitro and the in vivo situation. As described in chapter 9, AEC and VEC did not express these antigens in vitro. However, the expression could be induced by lymphokines. The production of these inducing lymphokines was inhibited by the immunosuppressive drug cyclosporin A. This action of cyclosporin A was used to study aspects of the regulation of endothelial MHC-class II antigen expression in vivo, as described in chapter 10. The disappearance of MHC-class II antigens from capillary endothelium in kidney and skin during administration of cyclosporin A demonstrated that the antigen expression is not a constitutive property of endothelial cells, but is dependent on lymphokines.

\section{Literature cited}

1. Monaco AP.

Clinical kidney transplantation in 1984 .

Transplant Proc 1985; 17: 5.

2. Salaman $J$, Briggs $\mathbb{D}$, Tayllor $\mathbb{R}$, Ting $A$.

An investigation into the centre ef fect: a report of a study conducted by the British Transplantation Society to analyse the centre effect at 8 renal units in the UK.

British Transplantation Society 1983.

3. Roitt J.

In: Essential Immunology 1984; pp. 269-270, Blackwell Scientific Publications.

4. Roitt $J_{\text {. }}$

In: Essential Immunology 1984; pp. 279-280, Blackwell Scientific Publications. 


\section{Stukart MJ.}

$\mathrm{H}-2$ regulation of $\mathrm{T}$ cell immunity angainst moloney leukemia virus.

Thesis 1983 (Amsterdam).

6. Unanue ER, Beller DJ, Lu CX, Allen PM.

Antigen presentation: comments on its regulation and mechanism.

I Immunol 1984; 132: 1.

7. Ting $\mathrm{A}_{\text {, Morris }} \mathrm{PJ}$.

Powerfull effect of HLA-DR matching on survival of cadaveric renal allografts.

Lancet 1980; 2: 282 .

8. Goeken NE, Thompson JS, Carry RJ.

A 2-year trial of prospective HLA-DR matching.

Transplantation 1981; $32: 522$.

9. Cerilli $\mathrm{J}$, Brasile L, Clarke J, Galowzis T.

The vascular endothelial cell (VEC) specific antigen system: three years experience in monocytes crossmatching.

Transplant Proc 1985; in press.

10. Steinmuller D, Tyler JD, David CS.

Cell-mediated cytotoxicity to non MHC alloantigerss on mouse epidermal cells. I H-2 ${ }^{\mathrm{k}}$ restricted reactions among strains sharing the $\mathrm{H}-2$ haplotype.

J Immunol 1981; 126: 1747 .

11. Steinmuller D, Tyler JD, David CS.

Cell-mediated cytotoxicity to non MHC alloantigens on mouse epidermal cells. III Genetic basis of the response of $\mathrm{C} 3 \mathrm{H}$ mice.

J Immunol 1981; 126: 1754.

12. Tyller JD, Steinmuller D.

Cell-mediated cytotoxicity to non MHC-alloantigens on mouse epidermal cells. III Epidermal cellspecific cytotoxic $T$ lymphocytes.

J Immunol 1981; 126: 1759 .

13. Steinmuller D, Tyler JD, Waddïck $\mathrm{KG}_{\text {, }}$ Burlingham WJ.

Epidermal alloantigen and the survival of mouse skin allografts.

Transplantation 1982; 33: 308.

14. Vegt PA, Buurman WA, vd Linden CJ, Daemen AJJM, Greep JM, Jeekel J.

Cell-mediated cytotoxicity toward canine kidney epithelial cells.

Transplantation $1982 ; 33 ; 465$.

15. Vegt PA.

Cell-mediated immunity toward kidney cells. An experimental study in dogs.

Thesis 1983 (Maastricht).

16. Steinmuller D.

Tissue-specific and tissue-restricted histocompatibility antigens.

Immunol Today 1984; 5: 234 .

17. Moraes JR, Stastny $\mathbf{P}$.

A new antigen system expressed in human endothelial cells.

J Clin Invest 1977; 60: 449.

18. Cerilli J, Holliday JE, Fesperman DP.

Role of antivascular endothelial antibody in predicting renal allograft rejection.

Transplant Proc 1977; 9: 771.

19. Paull LC, van Es LA, van Rood JJ, wan Leeuwen A, Brutel de la Riviere G, de Oraeff J,

Antibodies directed against antigens on the endothelium of peritubular capillaries in patients with rejecting renal allografts.

Transplantation 1979; $27: 175$.

20. Paul LC, Claas FHJ " van Es LA, Kalff MW, de Graeff J.

Accelerated rejection of a renal allograft associated with pre-transplantation antibodies directed against donor antigens on endothelium and monocyties.

New Eng J Med 1979; 300: 1258.

21. Baldwin III WM, Claas FHJ, wan Es LA, van Rood JJ.

Distribution of endothelial-monocyte and HLA antigens on renal vascular endothelium.

Transplant Proc 1981; 13: 103. 
22. Thompson JS, Overlin V, Severson CD, Parson TI, Herbick J, Strauss RG, Bums CP, Claas FHJ. Demonstration of granulocyte, monocyt and endothelial antigens by double fluorochromatic microcytotoxicity lesting.

Transplant Proc 1980; 12: 26.

23. Baldwin WM III, Claas FHJ, Paul LC, Springet TA, Hendriks GHJ, van Es LA, van Rood JJ. All monocyte antigens are not expressed on renal endothelium.

Tissue Antigens $1983 ; 21: 254$.

24. Ishii $Y$, Matsurara A, Iwaki H, Takami T, Kikuchi K.

Two closely related antigens expressed on granulocytes, macrophages and some reticular elements in rat lymphoid tissues: characterization by monocional antibodies. Immunology 1984: $51: 477$.

25. Knowles DM II, Tolidjian B, Marboe C, D'Agati V, Grimes M, Chess L.

Monoclonal anti-human monocyte antibodies OKMI and OKM5 possess distinctive hissue distribufions including differential reactivity with vascular endothelium.

J Immunol 1984: 132: 2170.

26. Wan Voorhis WC, Valinsky J, Hoffman E, Luban J, Hair LS, Steinman RM.

Relative efficacy of human monocytes and dendritic cells as accessory cells for $T$ cell replication.

$J$ Exp Med 1983; 158: 174.

27. Steinman RM, Nussenzweig MC.

Dendritic cells: features and functions.

Immunological Review 1980; 53: 127.

28. Steinman RM.

Dendritic cells.

Transplantation 1981; 31: 151 .

29. Brathen LR, Thorsby E.

Studies on human epidermal Langerhans cells. I Allo-activating and antigen presenting capacity. Scand J Immunol 1980; 11: 401 .

30. Chesnut RW, Grey HM.

Studies on the capacity of B cells to serve as antigenpresenting cells.

Clin Exp Immunol 1981; 126: 1075.

31. Pulford $\mathrm{K}$, Souhami RL.

The surface properties and antigen-presenting function of hepatic non-parenchymal cells.

Clin Exp Immunol 1981; 46: 581 .

32. Hirschberg $\mathrm{H}$, Bergh OJ, Thorsby $\mathrm{E}$.

Antigen-presenting properties of human wascular endothelial cells.

J Exp Med 1980; 152: 249S.

33. Groenewegen $G$, Buurman WA, Jeunhomme GMAA, Kootstra $G$.

Vascular endothelial cells present alloantigens efficiently (abstract).

Tramsplant Proc 1983; 15: 2201.

34. Durum SK, Gershon RK.

Interleukin 1 can replace the requirement for L-A positive cells in the proliferation of antigen-primed T cells.

Proc Natl Acad Sci USA 1982; 79: 4747.

35. Schultz RM, Kleinschmidt WJ.

Functional identity between murine $\gamma$-interferon and macrophage activating factor.

Nature 1983; 305: 239 .

36. Steeg PS, Moore RN, Johnson HM, Oppenheim JJ.

Regulation of murine macrophage la antigen expression by a lymphokine with immune interferon activity.

J Exp Med 1982; 156: 1780.

37. Sztein MB, Steeg PS, Johnson HM, Oppenheim Jd.

Regulation of human peripheral blood monocyte DR antigen expression in vitro by lymphokines and recombinant interferons.

J Clin Invest 1984; 73: 556 .

38. Widmer $\mathrm{MB}$, Bach FH.

Antigen-driven helper cell-independent cytolytic $T$ lymphocytes.

Nature 1981; 294: 750. 


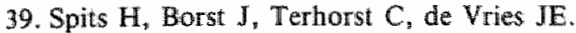

The role of differentiation markers in antigen-specific and lectin-dependent cellular cytotoxicity mediated by $\mathrm{T}^{+}$and $\mathrm{T} 4^{+}$human cytotoxic $\mathrm{T}$ cell clones directed at class I and class $\mathrm{II} \mathrm{MHC}$ antigens. IImmunol 1982; 129: 15.63.

40. Feaghery $C$, Stastny $P$.

HLA-D region-associated determinants serve as targets for human cell-mediated lysis.

J Exp Med 1979; 149: 485.

41. Johnson HE, Mossin J, Madsen M, Kristensen T, Kissmeyer-Nielsen F. Human B-blast specific target determinants in CML: a family study.

Tissue Antigens 1982; 19:222.

42. Mingari MC, Gerosa F, Carra G, Accolla RS, Moretta A, Zubler RH, Waldmann TA, Moretta L. Human interleukin 2 promotes proliferation of activated $B$ cells via surface receptors similar to those of activated $\mathrm{T}$ cells.

Nature 198:; 312: 641 .

43. Jaffe EA, Nachman RL, Becker CG, Minick CR.

Culture of human endothelial cells derived from umbilical vein.

J Clin Invest 1973; 53: 2745 .

44. Lightbody J, Bernoco D, Miggiano VC, Ceppellini R.

Cell mediated lympholysis in man after sensitization of effector lymphocytes through mixed leucocyte cultures.

J Bacterial Virol Immunol 1971; 64: 234.

45. Bach FH, Segall M, Zier KS, Sandel PM, Alter BJ, Bach ML.

Cell mediated immunity: separation of cells involved in recognitive and destructive phases.

Science 1973; 180: 403.

46. Buurman WA, Daemen AJJM, Groenewegen G, Does RJJM, vd Linden CJ, Vegt PA. Limiting dilution analysis of canine alloantigen reactive $T$ Iymphocytes.

Transplantation 1983 ; 15: 363 . 



\section{CHAPTER 3}

\section{Cellular cytotoxicity against canine endothelial cells}

Analysis of determinants recognized by CTL

Summary

A method is described which permits culture of both arterial and venous canine endothelial cells. Cell-mediated cytotoxicity against cultured endothelial cells has been studied. A ${ }^{51} \mathrm{Cr}$-release assay was used to detect CTL generated in MLC. Both arterial and venous endothelial cells are lysed by CTL specifically. Cold target inhibition experiments have been performed to analyse the CTL-recognized antigens on arterial and venous endothelial cells. Different antigens are recognized by CTL on venous endothelial cells and PHA-blasts; it is possible that CTL recognize venous endothelial cells through MHC-class II antigens or E-M antigens. Arterial endothelial cells and PHA-blasts share CTL-recognized antigens. 
It is likely that an important role is played by endothelium in organ allograft rejection, since in a vascularized allograft the endothelial cell is the first cell encountered by the recipient's immune system. Increasing attention is being given to endothelium in studies on organ transplant rejection. The presence of serological defined antigens on endothelial cells, among them MHC-class I antigens, has been described by several authors. Canine endothelial cells carry antigens not present on lymphocytes (1). Moraes and Stastny (2) identified E-M antigens which appeared to constitute a system of human alloantigens, present solely on endothelial cells and monocytes. During the study of humoral immune response in renal allograft recipients rejecting their grafts, circulating antibodies have been found directed against antigens on the endothelium of peritubular capillaries (3). Eluates from rejected renal allografts have been shown to contain antibodies reacting only with endothelial cells and monocytes of the specific kidney donors (4). No reaction has been observed with B-cells or T-cells of these donors.

Besides the endothelial cell-monocyte antigens, endothelial cells have been shown to express the antigens encoded for by the Major Histocompatibility Complex (MHC). Studies by Häyry et al. (5) have shown the presence of HLA-ABC and -DR locus antigens on human renal vasculature. Others have confirmed these data $(6,7,8)$. Mechanisms of endothelial damage have been investigated. Antibody dependent complement mediated cytotoxicity has been reported for both porcine and canine arterial endothelial cells $(9,10)$. Similar data have been reported for human umbilical vein endothelial cells in monolayers (11).

Canine arterial endothelial cells and cultured human umbilical vein endothelial cells appear to be stimulatory for allogeneic lymphocytes $(12,13,14)$. Cell-mediated cytotoxicity $(\mathrm{CMC})$ against cultured human umbilical vein endothelial cells and porcine aortic endothelium has been described $(10,15)$.

The demonstrated CMC against endothelium and the increasing knowledge of humoral detectable antigens on different parts of the vasculature have led to the investigation of $\mathrm{CMC}$ against endothelium and of antigens on endothelial cells recognized by cytotoxic T-lymphocytes (CTL), presented in this study. A ${ }^{31} \mathrm{Cr}$-release assay for CMC was used. CTL generated in vitro in mixed leukocyte culture (MLC), have been tested against both cultured arterial and venous canine endothelial cells. Cold target inhibition experiments have been performed to compare determinants recognized by CTL on arterial and venous endothelial cells. It is concluded that different antigenic determinants are recognized by CTL on venous endothelial cells and PHA-stimulated lymphocytes. However, arterial endothelial cells and PHA-blasts share determinants recognized by CTL.

Materials and methods

Endothelial cell culture. The external jugular vein and common carotid artery were 
unilaterally removed from living dogs under general anaesthesia. For some experiments vena cava inferior and aorta abdominalis were obtained fron dogs sacrificed in unrelated experiments. All branching vessels were tied before removal of the blood-vessels. The venous endothelium was exposed by eversion and rinsed with phosphate buffered saline (PBS). The artery was cannulated and flushed with PBS to remove remaining blood. The endothelial cells were obtained by collagenase treatment (16), modified in our laboratory. The arterial lumen was filled with a 1 $\mathrm{mg} / \mathrm{ml}$ collagenase solution (Sigma, St. Louis, U.S.A.) and the ewerted vein was submerged in this collagenase solution. The vessels were subsequently incubated for $15 \mathrm{~min}$ at $37^{\circ} \mathrm{C}$. The endothelial cells were collected in RPMI 1640 (Gibco Europe, Paisly, Scotland) or Dulbecco's Minimal Essential Medium (MEM) (Gibco) and centrifuged for $10 \mathrm{~min}$ at $400 \mathrm{~g}$; cells were resuspended in Dulbecco's MEM, supplemented with $20 \%$ foetal calf serum (FCS), penicillin and streptomycin $100 \mathrm{IU} / \mathrm{ml}$ respectively $100 \mu \mathrm{g} / \mathrm{ml}$. The cells obtained were cultured in gelatin-coated plastic culture flasks. Gelatin-coating was done by incubating the culture flasks for $18 \mathrm{~h}$ at $4^{\circ} \mathrm{C}$ with a $1 \%$ gelatin solution in PBS (Bacto gelatin, Difco, Detroit, U.S.A.) (17). The culture medium was decanted after $4 \mathrm{~h}$ at $37^{\circ} \mathrm{C}$ to free the cultures of nonadhering cells and materials. Culture flasks were placed in an incubator with a water saturated atmosphere containing $5 \% \mathrm{CO}_{2}$ at $37^{\circ} \mathrm{C}$. The culture medium was changed every 3 days. When cultures reached confluency, the cells were released by digestion with Dispase grad II (Boehringer, Mannheim, W. Germany) for $15 \mathrm{~min}$ at $37^{\circ} \mathrm{C}$ and subcultured. In all the experiments endothelial cells subcultured between 4 times and 8 times were used.

Cell-mediated cytotoxicity. Effector cells (CTL) were generated in a 6 day mixed leukocyte culture (MLC) of $10^{7}$ responder leukocytes and $5 \times 10^{6} 2500 \mathrm{rad} \mathrm{X}$-irradiated stimulator leukocytes. Leukocytes were prepared by buoyant density centrifugation on Lymphoprep (Nyegaard, Oslo, Norway). Cells were cultured in $10 \mathrm{ml}$ of RPMI 1640 supplemented with $10 \%$ heat inactivated canine serum and penicillin and streptomycin (MLC-medium). Incubation was at $37^{\circ} \mathrm{C}$ in a water saturated atmosphere containing $5 \% \mathrm{CO}_{2}$. On day 6 of culture cells were collected, counted and viability tested by trypan blue exclusion. Data on cell-concentrations refer to numbers of non-staining, living, cells.

Target cells. Arterial and venous endothelial cells in a confluent monolayer were released from culture flasks by $15 \mathrm{~min}$ of incubation at $37^{\circ} \mathrm{C}$ in $0.02 \%$ EDTA in PBS. Immediately after harvesting $\mathrm{Ca}^{2+}$ was replenished by the addition of an equal volume of MLC-medium. EDTA was used to prevent contamination of target cell suspension with enzymes absorbed to the cell-surface (18). Lymphocytes were stimulated for 3 days with an optimal dose of phytohaemagglutinin (PHA) to produce PHA-blasts.

Cell-mediated cytotoxicity assay (CMC-assay). Target cells were labeled by incubation for $45 \mathrm{~min}$ at $37^{\circ} \mathrm{C}$ with $200 \mu \mathrm{Ci} \mathrm{Na}{ }^{51} \mathrm{CrO}_{4}$ (specific activity $350-600 \mathrm{mCi} / \mathrm{mg}$ Cr) (Amersham, Amersham, England) and subsequently washed 3 times in MLCmedium. A constant number of $2.5 \times 10^{3}$ target cells was used in the cytotoxicity 
assay with varying numbers of effector cells in $0.2 \mathrm{ml}$ of MLC-medium. Tests were performed in microtiterplates in 4-fold. The plates were incubated for $6 \mathrm{~h}$ at $37^{\circ} \mathrm{C}$. The supernatant was harvested with supernatant harvesting cartridges (Skatron, Oslo, Norway) and counted in a gamma scintillation counter. Spontaneous release was determined by incubation in MLC-medium without effector cells; maximum release was determined by incubation with a detergent (Cetavlon).

Specific release in experiments was calculated as indicated:

specific release $=\frac{\text { experimental release }- \text { spontaneous release }}{\text { maximum release }- \text { spontaneous release }}$

Cold target inhibition experiments. Cold target inhibition was tested by addition of a varying number of unlabeled target cells (cold target) to $2.5 \times 10^{3}$ "1 $\mathrm{Cr}$-labeled target cells (hot target). PHA-stimulated lymphocytes were washed 3 times with $0.45 \%$ galactose in PBS to remove all PHA from the cells, in order to prevent lectin-dependent cytolysis or lectin-dependent binding of CTL to PHA-blasts.

\section{Results}

Culture of endothelial cells. The method used to obtain arterial and venous endothelial cells from blood-vessels, removed from living dogs, yielded sufficient living cells from $3-4 \mathrm{~cm}$ of blood-vessel to initiate a primary cell culture. The endothelial cells adhered to gelatin-coated plastic culture flasks within $4 \mathrm{~h}$. Proliferation was observed to start immediately. A difference in growth rate between arterial and venous endothelial cells was noted. Vein-derived cells proliferated at a faster rate than artery-derived cells. Confluency in a monolayer was reached within a few days, depending on the number of cells brought in culture initially. The adherence and growth of both kinds of endothelial cells was strongly dependent on the brand and batch of plastic used. Such differences were completely abolished by gelatin-coating of the plastic culture flasks. Cultured cells have been identified as endothelial cells by their growth pattern in monolayers, their positive immunofluorescence with anticanine F VIII (16) and their microscopical appearance. Arterial cells showed less fluorescence to anti-F VIII than did venous cells.

In monolayers the cells have an appearance of closely apposed non-overlapping elongated mononuclear cells. The cytoplasm contains a few fine granules and is without vacuoles. The nucleus is sharply demarcated and has 2-3 nucleoli. Mitotic figures are frequently seen before confluency is reached. In general, arterial cells are a little smaller than venous endothelial cells (Figure 1).

Cultures were incidentally contamined with spindle shaped cells not fulfilling the afore-mentioned criteria for endothelial cells. These contaminating cells did not grow in a monolayer and frequently showed a "hill and valley pattern". These cells were regarded as smooth muscle cells. The contaminated cultures were not used in subsequent experiments. 
Figure 1. Micrascopic ihustrations of cuttured canine endothelial cells (final magnification $x^{2}$ and.

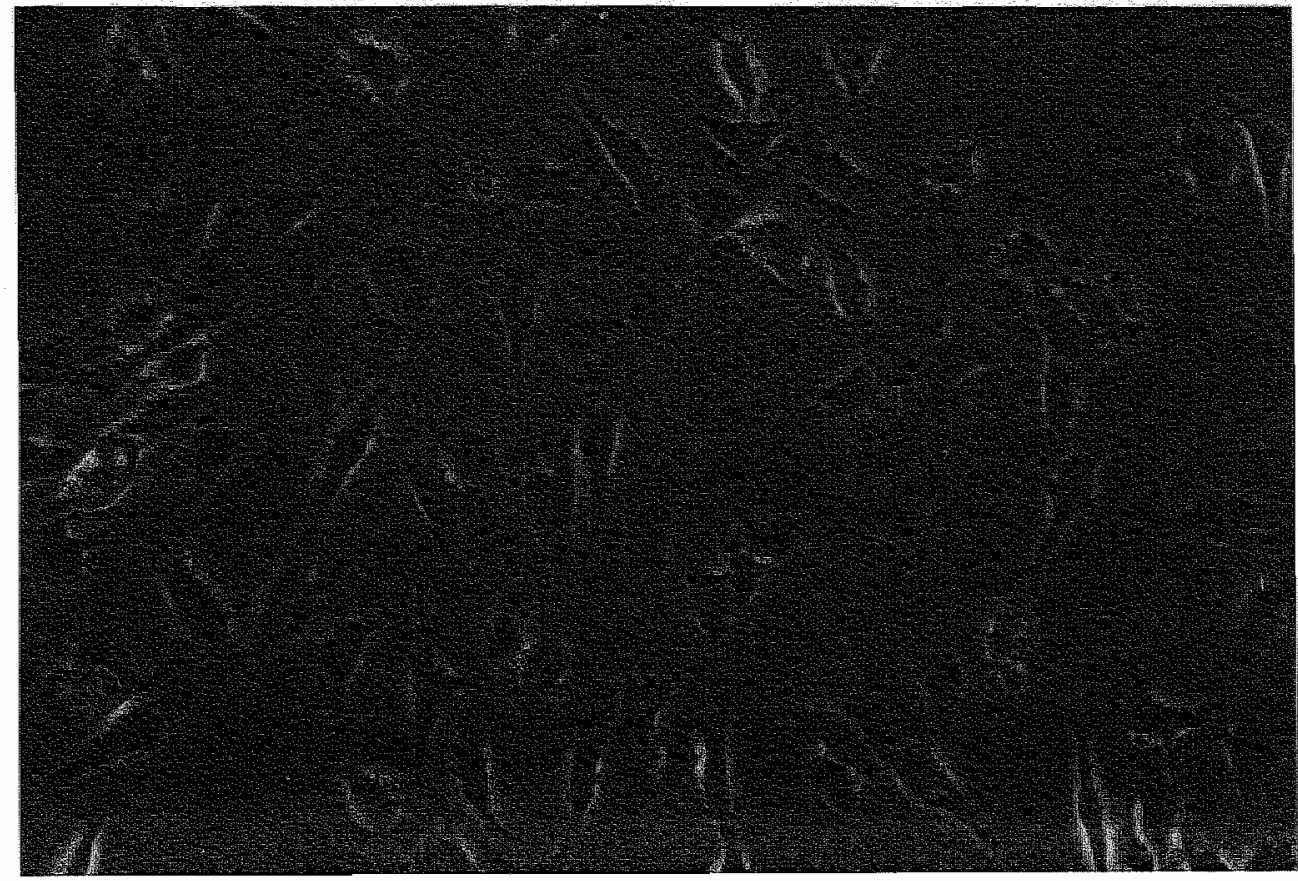

Arterial endothelial cells in phase microscopy.

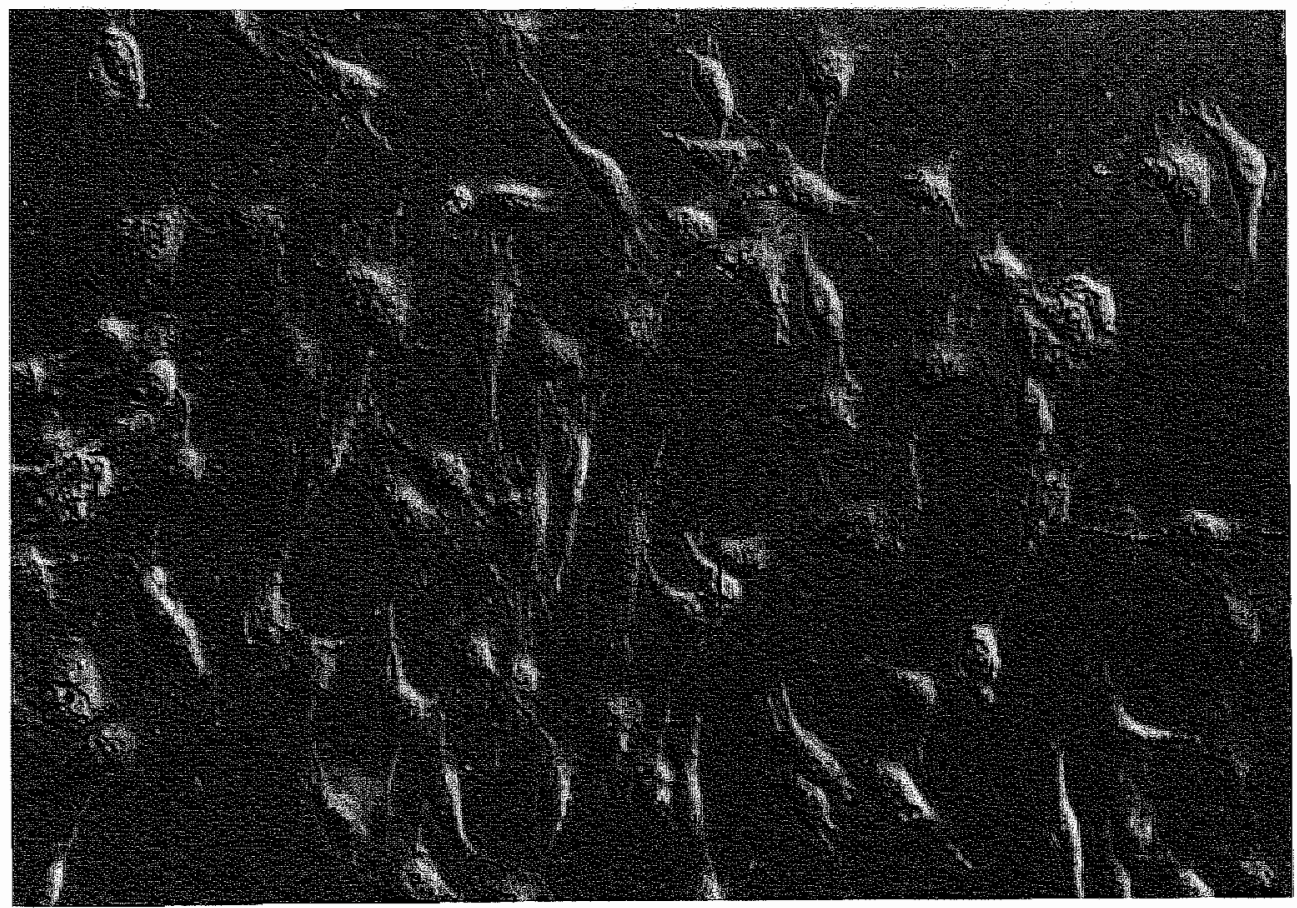




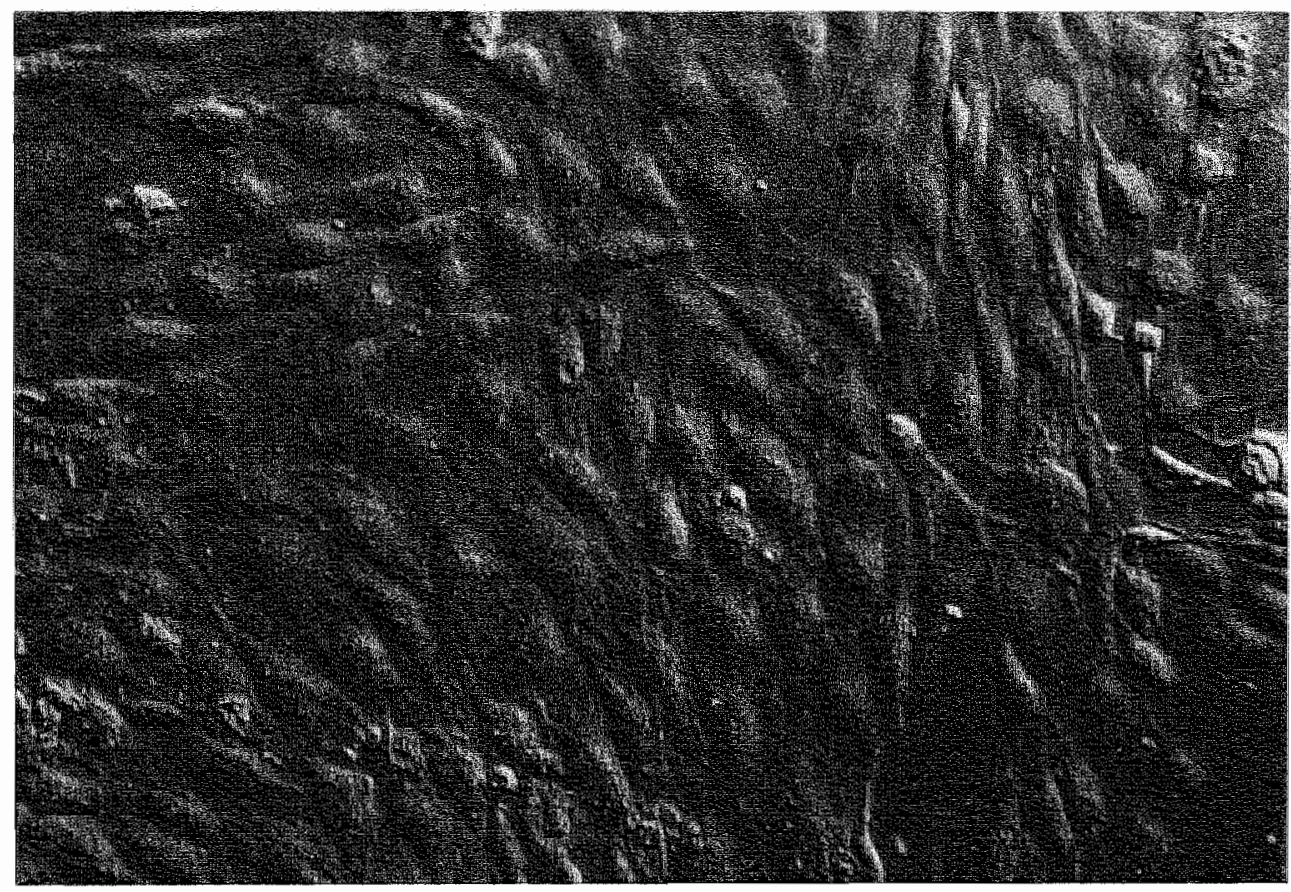

Venous endothelial cells in phase microscopy.

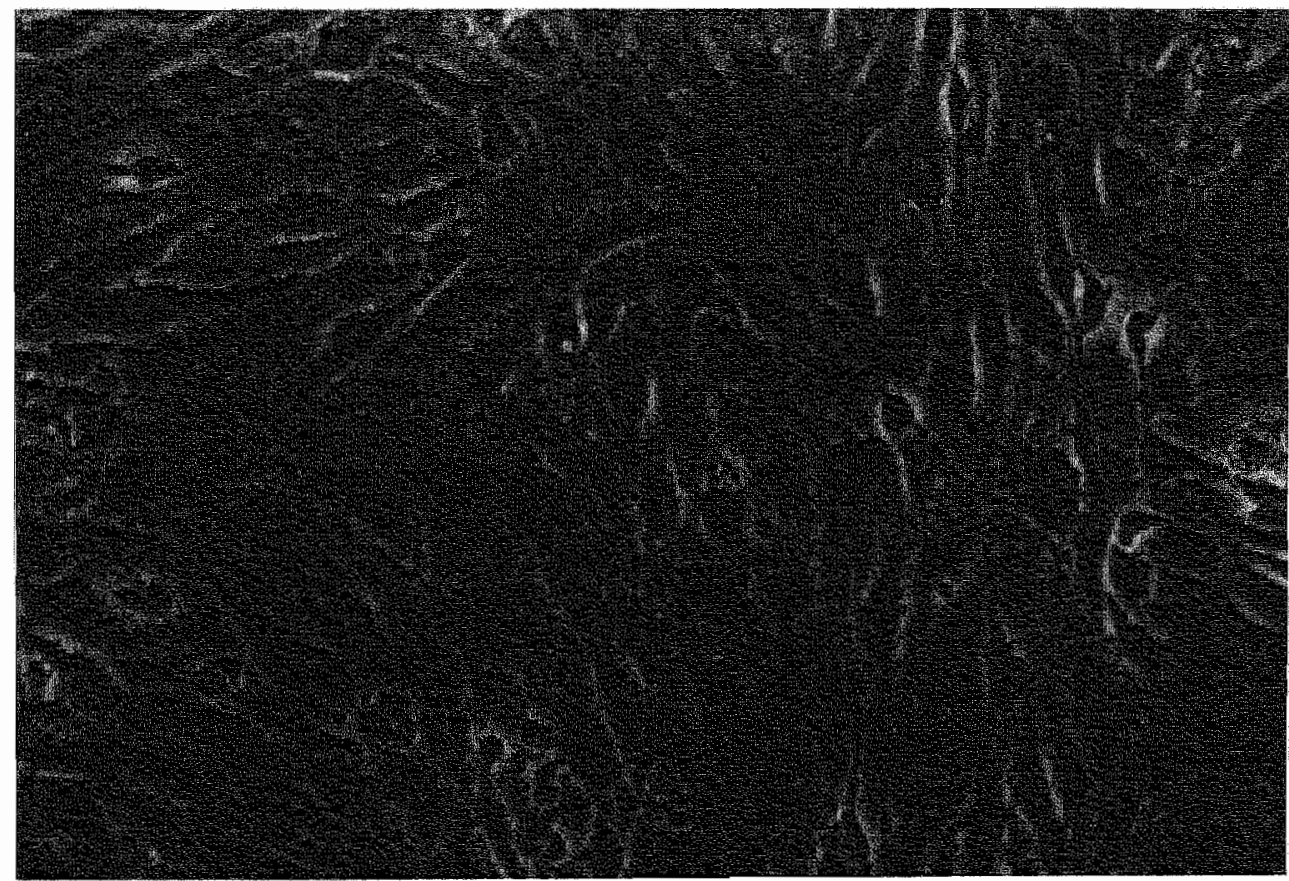

Venows endorhelial cells in differential interference microscopy. 
Cell-mediated cytotoxicity. A cell-mediated cytotoxicity assay using ${ }^{51} \mathrm{Cr}$-labelled cultured canine arterial and venous endothelial cells was developed in analogy to the CMC-assay for cultured canine kidney cells described by Buurman et al. (19) and Vegt et al. (20). Both kinds of cultured canine endothelial cells and PHA-blasts were useful targets in the CMC-assay. Spontaneous release of these targets ranged from $10-35 \%$ of ${ }^{51} \mathrm{Cr}$-uptake; maximum release generally exceeded $80 \%$ of ${ }^{51} \mathrm{Cr}$-label contained. Data of 11 experiments are given in Table 1.

CTL generated in mixed leukocyte culture are demonstrated to lyse cultured arterial and venous endothelial cells and PHA-blasts of the stimulator. Specific releases ranged from $18-88 \%, 19-57 \%$ and $34-76 \%$, respectively, in these experiments.

In control experiments attention was paid to the susceptibility of target cells to lysis by nonspecific cytotoxic cells, e.g. natural killer cells. Target cells were incubated with effector cells generated in MLC, effector cells being syngenic to the target cells. Data from these experiments are given in Table 1. Lysis of venous endothelial cells ranged from $-1 \%$ to $-25 \%$, lysis of arterial endothelial cells from $4 \%$ to $-15 \%$, lysis of PHA-blasts from $-5 \%$ to $-13 \%$. It appears that endothelial cells are not susceptiblle to lysis by nonspecific cytotoxic cells.

Further control experiments were performed with endothelial cells from dogs unrelated to the dog used as stimulator in MLC. In four consecutive experiments lysis of venous endothelial cells ranged from $-2 \%$ to $-20 \%$ and of arterial endothelial cells from $-4 \%$ to $-26 \%$ (data not shown).

Cold target inhibition experiments. In order to analyse determinants on endothelial cells recognized by CTL, nine cold target inhibition experiments were performed. Hot, ${ }^{51} \mathrm{Cr}$-labelled target cells in a fixed quantity of $2.5 \times 10^{3}$ cells were mixed with varying number of cold, unlabelled cells and incubated with effector cells for $6 \mathrm{~h}$. Hot target-cold target ratios ranged from 1:0 to 1:32. For every hot target-cold target ratio spontaneous release was determined by the incubation of mixed hot and cold target cells without effector cells. The addition of unlabelled target cells did not lead to an increase of spontaneous release.

The experimental system was tested by the addition of cold target cells to indentical hot target cells, which should result in the inhibition of lysis. One of the control experiments is shown in Figure 2. It depicts results similary found in nine consecutive experiments. The addition of cold PHA-blasts to hot PHA-blasts of the same animal resulted in a decrease of ${ }^{51} \mathrm{Cr}$-release in a dose dependent way, resulting in $51 \%$ inhibition of lysis at $80 \times 10^{3}$ cold target cells added, i.e. $49 \%$ specific lysis without cold target cells, versus $24 \%$ when $80 \times 10^{3}$ cold PHA-blasts were added. The addition of cold PHA-blasts to hot PHA-blasts of an unrelated animal did not result in a reduced ${ }^{51} \mathrm{Cr}$-release; on the contrary, an increase of lysis of $12 \%$ was observed with the addition of $80 \times 10^{3}$ cold unrelated PHA-blasts. Similar results were found for arterial and venous endothelial cells. It is concluded that the experimental system allows the detection of competition for determinants.

From a series of nine cold target inhibition experiments, two representative sets of results are shown in Figure $3 a$ and $b$. The addition of increasing numbers of cold 


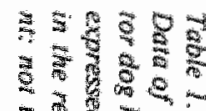

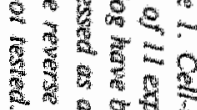
- 2 . 3. O $E$ E 월 3 .

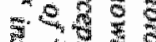
6. 굴 Q 58 is 5 है $6=$ 政 造起 露 1)

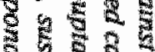
的 을 5 है 35

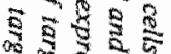

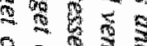

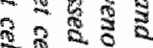

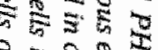
은 3

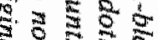
है 2.

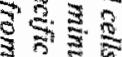

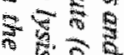
골 (3) 的客 晋

政

管

올

क्ष

s.

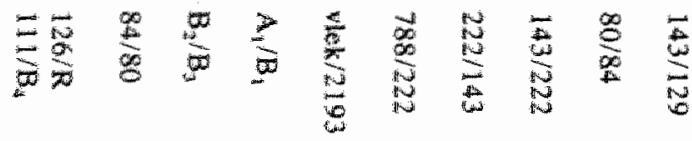

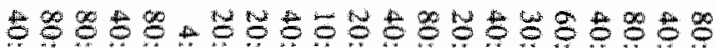

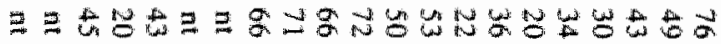

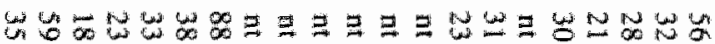

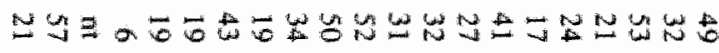

1

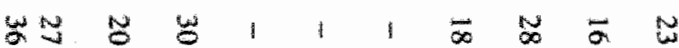

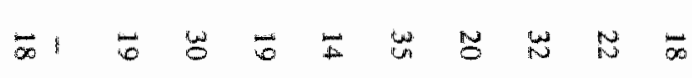

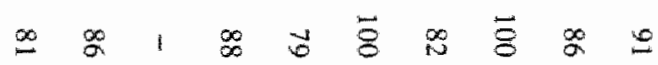

un $991,1,0=\infty$

w1 \& u

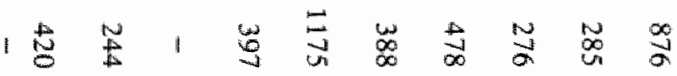

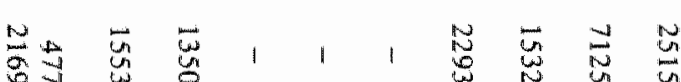

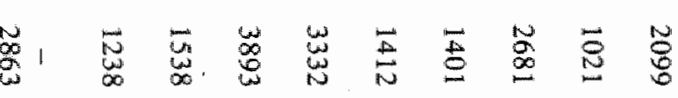

in $\frac{1}{\omega} 1 \equiv \equiv \equiv b b \equiv \frac{1}{\omega}$

$\infty \frac{1}{4 \pi} \quad 1$

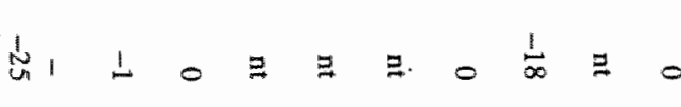

要要意

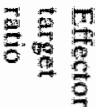

$\frac{5}{2}$

$-$

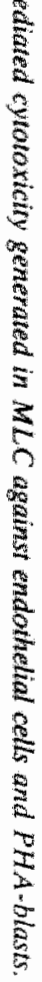

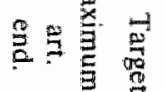

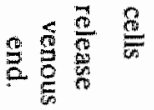

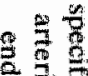

政

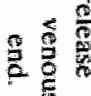

焉

을

\begin{tabular}{l|l}
3 \\
3 \\
3
\end{tabular}

勇

劉

-

를

蛋

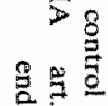

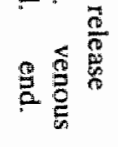




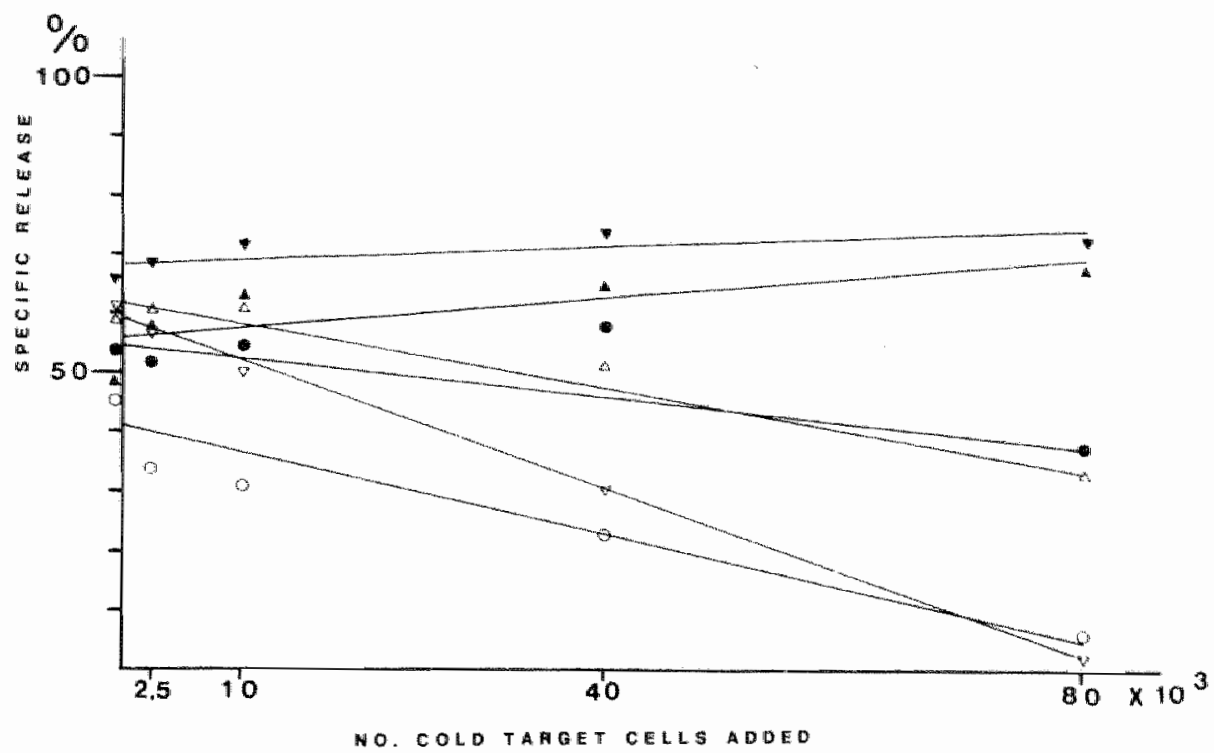

Figure 2. Cold target inhibition control experiments. The percentages of speclfic lysis have been plotted against the number of cold target cells added to $2.5 \times 10^{3}$ hot target cells.

$\checkmark$ cold PHA-blasts added to hot PHA-blasts of the same dog.

- cold PHA-blasts of an unrelated dog added to hot PHA-biasts.

- cold venous cells added to hot venous cells of the same dog.

- cold venous cells of an unrelated dog added to hot venous cells.

a cold arterial cells added to hot arterial cells of the same dog.

4 cold arterial cells of an unrelated dog added to hot arterial cells.

Lines drawn have been calculated by linear regression analysis of experimental data.

venous endothelial cells to hot PHA-blasts of the same dog did not result in a significant reduction of lysis of hot PHA-blasts; specific lysis was $62 \%$ at $80 \times 10^{3}$ cold venous endothelial cells added versus $66 \%$ at $2.5 \times 10^{3}$ cold cells added (Figure 3a). Specificity was tested by the addition of cold venous endothelial cells of an unrelated animal. The absence of inhibition of lysis indicated that competition for determinants recognized by CTL present in the effector cell population on venous endothelial cells and PHA-blasts of the same dog did not occur. This finding is in contrast to the results obtained in cold target inhibition experiments performed with arterial endothelial cells. The addition of cold arterial endothelial cells to hot PHA-blasts of the same dog did result in the inhibition of lysis of PHA-blasts; specific lysis was $1 \%$ at $80 \times 10^{3}$ cold arterial endothelial cells added versus $22 \%$ at $2.5 \times 10^{3}$ cold cells added (Figure $3 \mathrm{~b}$ ). This inhibition was specific, as inhibition was not observed on the addition of cold arterial endothelial cells of an unrelated dog to PHA-blasts. This demonstrates competition for determinants recognized by CTL on arterial endothelial cells and PHA-blasts of the same dog, indicating that these cells share determinants recognized by CTL. It is concluded that venous endothelial cells and PHA-blasts are recognized by CTL through different determinants, whereas arterial 

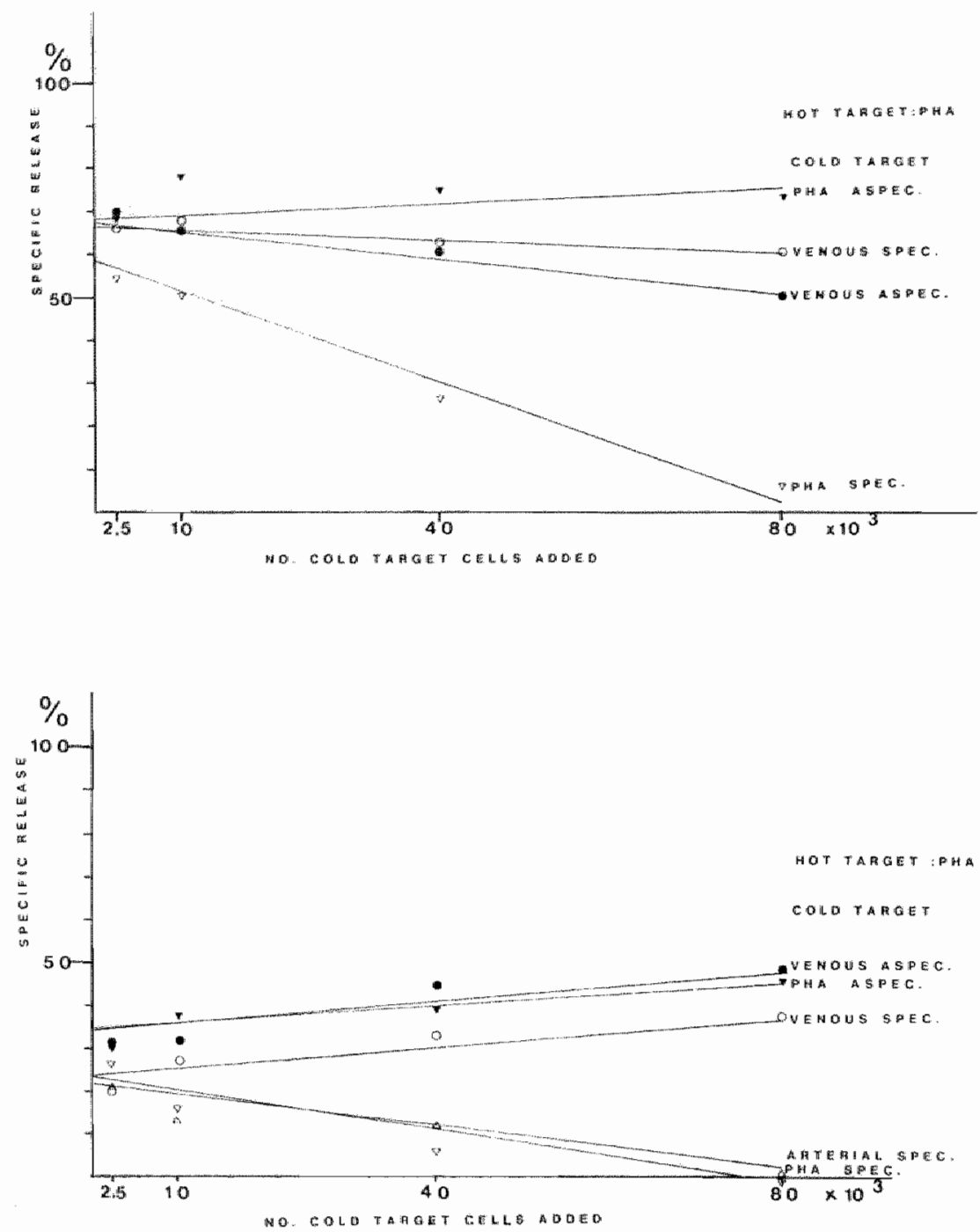

Figure $3 a$ and b. Cold target inhibition experiments. The percentages of specific lysis have been plotted against the num ber of cold target cells added to $2.5 \times 10^{3}$ hot PHA-blasts.

Lines drawn have been calculated by linear regression analysis of experimental data.

endothelial cells and PHA-blasts are recognized at least partly through identical determinants.

Discussion

Endothelial cells used in the experiments reported in this paper were obtained from 
both the arteries and veins of dogs. This procedure permitted a continuous culture of both arterial and venous endothelial cells originating from one dog, without sacrificing the animal. Thus future collection of blood remained possible. Complications due to cerebral ischaemia have not been observed in the operated dogs. In the study of renal allograft rejection an important role has been suggested for specific anti-endothelial antibodies $(3,4)$. Cellular immunological defence against allogenic endothelium has, however, hardly been studied. Several reports have shown endothelial cells to be stimulatory to allogenic lymphocytes in mixed cultures, as the in vitro correlate of the afferent limb of rejection in organ allografting. In the first report claiming this stimulating capacity of endothelial cells, stimulating cells were used that had not been clearly indentified as endothelial cells $(1,12)$. Hirschberg et al. $(13,14)$ conclusively demonstrated the stimulating capacity of human umbilical vein endothelial cells to allogenic human lymphocytes in mixed cultures. Cellmediated cytotoxicity in vitro must be considered as the efferent limb of cellular immunity in causing tissue damage during rejection. $\mathrm{CMC}$ against endothelial cells has been demonstrated in in vitro assays. De Bono et al. (10) used cultured porcine aortic endothelial cells and measured ${ }^{3} \mathrm{H}$-adenine-uptake of endothelial monolayers after incubation with primed lymphocytes. This assay seems to have disadvantages of long incubation times and subjective quantitation of target cell numbers and therefore has limited applications for related experimental purposes. We therefore used a ${ }^{51} \mathrm{Cr}$-release assay, which was used with good results by Hirschberg et al. (15) for human umbilical vein endothelial cells. We postulate arterial and venous endothelial cells to be more relevant in transplantation research, since umbilical vein lining cells may have unique antigenic characteristics due to their place and function in foetal-maternal circulation.

With the ${ }^{51} \mathrm{Cr}$-release assay it has been demonstrated that cultured arterial and venous endothelial cells are lysed by CTL generated in mixed leukocyte culture. In our opinion the reported cell-mediated cytotoxicity against endothelial cells is not only an in vitro occurrence, but it has its role in organ allograft rejection. Possibly the thrombosis seen in rejected kidneys is the result of activation of circulating blood coagulation factors, activated by endothelial cells damaged by CTL.

The determinants recognized by CTL on endothelial cells were analysed by cold tar get inhibition techniques. The addition of unlabelled, cold, venous endothelial cells in several ratios to labelled, hot, PHA-blasts of the same donor-dog did not inhibit lysis of PHA-blasts by CTL from MLC. The absence of competition for determinants indicates a difference in target-antigens recognized on venous endothelial cells and PHA-blasts.

CTL recognize both $\mathrm{MHC}$-class $\mathbb{I}$ and $\mathbb{I I}$ antigens of $\mathrm{MHC}$ on lectin-stimulated B-lymphocytes and monocytes used as targets in CMC-assays $(21,22)$. PHA-blasts carry only MHC-class I antigens and, after 4 days of cultured, possibly a detectable amount of MHC-class II antigens (23). Although these data refer to human cells, similar findings for canine cells are likely. Since the PHA-blasts used carried only MHC-class I antigens, it is concluded that CTL from MLC did not attack MHC- 
class I antigens on the venous endothelial cells. As venous endothelial cells can be lysed by CTL, other antigens must be attacked. MHC-class II antigens and endothelial cell-monocyte antigens (E-M antigens) were reported to be present on the venous endothelial cell. CTL were generated in mixed leukocyte culture with a stimulating cell suspension containing B-lymphocytes, carrying MHC-class II antigens, and monocytes, carrying the E-M antigen. From this we concluded that these antigens are likely to be involved in CTL-recognition of venous endothelial cells.

Inhibition was observed on the addition of cold arterial endothelial cells to hot PHAblasts of the same dog. This indicates a similarity of antigens recognized by CTL on arterial endothelial cells and PHA-blasts. Arterial endothelium might not contain DR-antigens as found in man for renal arterial endothelium (W.M. Baldwin, personal communication). This is also likely for the canine arterial endothelium. Since inhibition of lysis of PHA-blasts has been observed on the addition of arterial endothelial cells of the same dog, common antigens must be recognized. As both cell types carry MHC-class I antigens, it is likely that CTL also recognize MHC-class I antigens on arterial endothelial cells and PHA-blasts. An alternative explanation for the lack of inhibition observed on the addition of venous endothelial cells might be that the populations of CTL generated in MLC recognize two different determinants, both of them appearing on PHA-blasts and only one on venous endothelial cells. As inhibition of lysis of PHA-blasts was found on the addition of arterial endothelial cells, this is suggested the presence of both putative PHA-blast-determinants on arterial endothelial cells. The addition of unlabelled venous endothelial cells to labelled PHAblasts would be expected to result in partial inhibition of lysis of PHA-blasts. However, partial inhibition was not observed on the addition of venous endothelial cells. In recent years techniques have been developed to analyse CTL recognizing one determinant at a clonal level. These techniques have recently been developed in our laboratory in a canine model (24). Elaboration of these techniques for endothelial cells will permit us to analyse and compare determinants recognized by CTL at a clonal level of CTL on arterial and venous endothelial cells, as well as on monocytes, carrying MHC-class I and II and E-M antigens, and B-lymphocytes, carrying MHC-class I and II antigens.

We have demonstrated the cell-mediated cytolysis of both arterial and venous endothelial cells in culture. A difference in CTL-recognized determinants on these two vascular lining cells is likely. These differences in antigens, possibly tissue and location-specific, are a subject for further study. Attention should be paid to the microcapillary endothelial cells as well, since these cells can be of vital importance in organ allograft rejection.

\section{Acknowledgements}

Mrs A.J.J.M. Daemen is thanked by the authors for her skilful technical assistance and Mrs N. Castermans and Miss M. van den Berg for their secretarial assistance. This work has been supported by the Dutch Kidney Foundation (Nierstichting Ne- 


\section{Literature cited}

1. Vetto RM, Burger DR.

The identification and comparison of transplantation antigens on canine vascular endothelium and lymphocytes.

Transplantation $1971 ; 11: 347$.

2. Moraes JR, Stastny $P$.

A new antigen system expressed in human endothelial cells.

J Clin Invest 1977; 60: 449 .

3. Paul LC, van Es LA, van Rood JJ, van Leeuwen A, Brutel de la Rivière $\mathrm{G}$, de Graeff $J$.

Antibodies directed against antigens on the endothelium of peritubular capillaries in patients with rejecting renal allografts.

Transplantation 1979;27: 175 .

4. Claas FHJ, Paul LC, van Es LA, van Rood JJ.

Antibodies against donor antigens on endothelial cells and monocytes in eluates of rejected kidney allografts.

Tissue Antigens 1980; 15: 19.

5. Häyry $P$, won Willebrand $E$, Andersson LC.

Expression of HLA-ABC and DR locus antigens on human kidney, endothelial, tubullar and glomerular cells.

Scand J Immunol 1980; 11: 303.

6. Hart DNJ, Fuggle SV, Williams KA, Fabre JW, Ting A, Morris PJ.

Localization of HLA-ABC and DR antigens in human kidney.

Transplantation 1981; $31: 428$.

7. Natali PG, De Martino C, Marcellini M, Quaranta V, Ferrone S.

Expression of la-like antigens on the vasculature of human kidney.

Clin Immunol Immunopathol $1981 ; 20,11$.

8. Scott H, Brandtzaeg P, Hirschberg H, Solheim BG, Thorsby E.

Vascular and renal distribution of HLA-DR-like antigens.

Tissue Antigens 1981; 18: 195.

9. De Bono DP.

Effects of cytotoxic sera on endothelium in vitro.

Nature 1974; 252; 83.

10. De Bono DP, Macintyre DE, White DJG, Gordon JL.

Endothelial adenine uptake as an assay for cell- or complement-mediated cytotoxicity.

Inmunology 1977; 32: 221 .

11. Hïrschberg $\mathbb{H}$, Moen $\mathbb{T}$, Thorsby $\mathbb{E}$.

Specific destruction of human endothelial cell monolayers by anti-DRw antisera.

Transplantation $1979 ; 28: 116$.

12. Vetto RM, Burger DR.

Endothelial cell stimulation of allogenic lymphocytes.

Transplantation 1972; 14: 652 .

13. Hirschberg $H$, Evensen $S A$, Hendriksen $T$, Thorsby $E$.

Stimulation of human lymphocytes by allogenic endothelial cells in vitro.

Tissue Antigens 1974; $4: 257$.

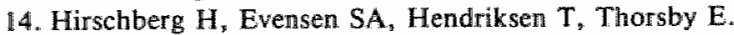

The human mixed lymphocyte-endothelium culture interaction.

Transplantation 1975; 19: 495. 
15. Hirschberg $H$, Rolstad $B$, Thorsby $E$.

The role of human endothelial cells in allograft rejection.

Scand J Urol Nephrol Suppl. 1975; $29 ; 33$.

16. Jaffe EA, Nachman RL, Becker CO, Minick CR.

Culture of human endothelial cells deriwed from umbifical vein.

J Clin Invest $1973 ; 52: 2745$.

17. Folkman J, Haudenschild $\mathrm{CC}$, Zetter BR.

Long-term culture of capilary endothelial cells.

Proc Natl Acad Sci USA 1979; 79: 5217.

18. Poste: $\mathrm{G}$.

Tissue dissociation with proteolytic enzymes.

Exp Cell Res 1971; 65: 359.

19. Euurman WA, Vegt PA, van der Linden CI, Greep JM.

Cellular cytotoxicity generated in a canine mixed kidney lymphocyte cell culture.

Thissue Antigens 1981; 18: 326 .

20. Vegt PA, Buurman WA, van der Linden CJ, Daemen AJJM, Greep JM, Jeekel J.

Cell-mediated cytotoxicity toward canime kidney epithelial cells.

Transplantation 1982; 33: 465.

21. Feighery $C$, Stasiny $P$.

HLA-D region associated determinants serve as targets for human cell-mediated lysis.

J Exp Med 1979; 149:485.

22. Johnsen $\mathrm{HE}$.

Human B blast specific target determinants in CML: a methodological study.

Tissue Antigens 1980; 15:189.

23. Ko HS, Fu SM, Winchester RJ, Yu DTY, Kunkel HG.

la Determinants on stimulated human $T$-lymphocytes.

J Exp Med 1979; 150: 246.

24. Buurman WA, Daemen AJJM, Groenewegen G, Does RJJM, van der Linden CJ, Vegt PA.

Limiting dilution analysis of canine alloantigen reactive $T$-lymphocytes.

Transplantation 1983; 35: 363 . 


\section{CHAPTER 4}

\section{Cell mediated cytotoxicity patterns of cloned cytotoxic T lymphocytes}

Cytotoxicity directed against canine lymphoblasts, monocytes and endothelial cells.

\section{Summary}

Knowledge of the antigens recognized during allograft rejection is still incomplete. Cloned cytotoxic T lymphocytes were used to study the distribution of target determinants in the dog.

CTL clones were obtained with a limiting dillution technique from effector cells generated in mixed lymphocyte culture. The clones have been tested for cellmediated cytotoxicity against PHA-stimulated lymphoblasts, monocytes and arterial and venous endothelial cells. A limited number of patterns of lysis of one or more than one of the four different target cells was observed.

The nature of the possible target determinants recognized by these CTL-clones is discussed. 
Knowledge of the antigens recognized during allograft rejection is still incomplete. In vitro and in vivo studies indicated a role of major importance for the antigens encoded for by the Major Histocompatibility Complex (MHC). Class II-products induce proliferation and differentation of lymphocytes, and class 1-products are the antigens recognized by the cytotoxic $T$ lymphocytes (CTL) for lysis. Further studies demonstrated however that besides lymphocyte activation, MHC-class II products could also serve as target determinants for cell-mediated cytotoxicity $(1,2)$. Tissue specific determinants have been demonstrated to serve as targets for cell-mediated cytotoxicity against murine epidermal cells (3) and canine epithelial kidney cells (4). We recently presented data on the different determinants recognized by CTL generated in mixed lymphocyte culture (MLC) on lymphoblasts, on cultered arterial and on venous endothelial cells as detected with cold target inhibition experiments (5). Here we report data on the specificity of cloned CTL generated in MLC. The reactivity pattern of these CTL clones with lymphoblasts, monocytes, arterial and venous endothelial cells as target cells has been studied. It appeared that a limited number of patterns of lysis of one or more target cells by the CTL clones was found. The putative determinants involved in target cell lysis are discussed.

Materials and methods

Mixed leukocyte culture. Leukocytes were prepared from canine heparinized peripheral blood by buoyant density centrifugation on Lymphoprep (Nyegaard, Oslo, Norway). Unidirectional mixed leukocyte cultures were performed by culturing $10^{7}$ responder leukocytes with $5 \times 10^{6}, 4000 \mathrm{rad} X$-irradiated, stimulator leukocytes, 2 DLA-haplotype different and non-related, in $10 \mathrm{ml}$ of RPMI 1640 (Gibco Europe, Paisley, Scotlland) containing $10 \%$ heat inactivated canine serum and $100 \mathrm{IU} / \mathrm{ml}$ penicillin and $100 \mu \mathrm{g} / \mathrm{ml}$ streptomycin. Cultures were kept in an incubator at $38^{\circ} \mathrm{C}$ with a watersaturated atmosphere of air containing $5 \% \mathrm{CO}_{2}$.

Cloning of cytotoxic $T$ lymphocytes. On day 6-8 of MLC, 0.3 viable cell per well. was seeded in round bottomed microwells (Greiner, Nürtingen, FRG). The cells were cultured in $0.2 \mathrm{~mL}$ RPMI 1640 supplemented with $10 \%$ canine serum, Interleukin 2 (Il-2) and $10^{5}, 4000$ rad X-irradiated, stimulator leukocytes. Il-2 was produced by EL4 thymoma cells, as reported before (6) and was used in an optimal concentration for growth of canine Il-2-dependent cells. At day 7-9 after cloning the microwells were split in two and refed with Il-2. Three days later the wells were screened macroscopically and microscopically for growth of lymphocytes. The cells, in the wells that showed growth, were resuspended, transferred to a new microtiterplate and split in 2 or 3 wells. The cells were refed with $10^{s}$ irradiated stimulator leukocytes per well and II-2. During furcher culture the wells were split twice weekly at an 1:2 or 1:3 ratio and refed with II-2. Once weekly $10^{5}$ irradiated stimulator leukocytes were added to the wells. Cells were subcultured untill sufficient cells were 
obtained for cell-mediated cytotoxicity assays in multiple folds and for storage in liquid nitrogen.

Cell-mediated cytotoxicity assays. Cell-mediated cytotoxicity (CMC) assays for arteriall endothelial cells (AEC), for venous endothelial cells (VEC) and for lectin free phytohaemagglutinin stimulated lymphoblasts (PHA-blasts) have been described before (5). Monocytes (M $\phi$ ) were prepared by plastic adherence. Freshly prepared peripheral blood leukocytes were incubated for $1 \mathrm{hr}$ at $38^{\circ} \mathrm{C}$ in RPMI 1640 containing $10 \%$ foetal calf serum (FCS) in tissue culture flasks; approximately $4 \times 10^{5}$ leukocytes per square centimeter were used. Non-adherent cells were washed off extensively; M $\phi$ were released by lidocaine-treatment (7), washed and resuspended in RPMI 1640 containing $10 \%$ canine serum.

From then on $\mathrm{M} \phi$ were kept in siliconized glass tubes to prevent adhesion. The $\mathrm{M} \phi$ were labeled with ${ }^{51} \mathrm{Cr}$, similar to AEC, VEC and PHA-blasts. Target cells, $2.5 \mathrm{x}$ $10^{351} \mathrm{Cr}$-labeled cells, were added to cells to be tested for cytotoxicity.

Cell-free supernatant was harvested after $4 \mathrm{hr}$ incubation at $38^{\circ} \mathrm{C}$ and counted for

${ }^{51} \mathrm{Cr}$-content. Spontaneous ${ }^{51} \mathrm{Cr}$-release of each target was determined by incubation in RPMI 1640 plus $10 \%$ serum. CMC was assayed at least in triplicate against the four target cells.

Cloned T lymphocytes were tested for CMC against the different target cells in equal quantities. This constant effector: target ratio allowed proper comparison of lysis of the four target cells in each individual experiment.

Clones which caused a ${ }^{51} \mathrm{Cr}$-release exceeding the mean spontaneous release plus three standard deviations were arbitrarily considered positive for $\mathrm{CMC}$ against the specific target cell.

\section{Results}

Statistical data on cloning procedure. CTL were cloned with the use of a limiting dilution technique: 0.3 cell per well was seeded in micrawells containing exogenous Il-2 and irradiated stimulator cel]s. A limiting dilution procedure does not by itself guarantee clonal purity of the wells positive for growth of cells. Statistics provide circumstantial evidence for clonal purity. Three MLC experiments were used to obtain the data presented in this report; the cells from each MLC experiment were seeded in three microtiterplates, containing 96 wells. Calculations based on the Poisson distribution, for the actual number of cells seeded per well, and the binominal distribution, for the number of reactive cells per well, permits determination of the probability of growth caused by one seeded cell per well and the probability of growth caused by more than one cell seeded per well. The data necessary for calculation are the number of cells seeded per well, the number of wells seeded and the number of non-reacting wells, obtained with the limiting dilution technique. In experiment I 288 wells seeded with 0.3 cell, 14 wells with growth were obtained. The probability that a well was seeded with a single cell was $0.0474 ;$ the probability that a well was seeded with more than one cell was 0.0012 . It can be concluded that 

$\frac{0.0012 \times 288}{14} \times 100 \%=2.5 \%$ of the population originated from more than one cells. In experiment II, 22 populations were obtained from 288 wells. The probabilities for one cell per well and for more than one cell per well were respectively 0.0734 and 0.0029 . The fraction of cell populations to originate from one or from more than one cell were $96.1 \%$ and $3.9 \%$. In experiment III, 64 cell populations were obtained from 288 wells. The probabilities for one cell and for more tham one cell per well were 0.1955 and 0.0267 respectively, implicating on statistical grounds $88.0 \%$ of the cell populations to be clonally pure, and $12.0 \%$ of the cell populations to originate from more than one cell. Bach (8) referred to cell population obtained in limiting dilution experiment as 'cloids', to distinguish them from 'real' clones. We con-

Table 1. Cell-mediated cytotoxicity of clanes CTL from MLC against lymphoblasts, monocytes, and arterial and venous endothelial cells.

\begin{tabular}{|c|c|c|c|c|c|c|c|c|}
\hline \multirow{2}{*}{$\begin{array}{l}\text { Clome } \\
\text { identi- } \\
\text { fication }\end{array}$} & \multicolumn{4}{|c|}{ Percentage specific lysis of } & \multicolumn{4}{|c|}{ Discrimination ${ }^{b} \mathrm{pos} / \mathrm{neg}$} \\
\hline & $\begin{array}{l}\text { Lympho- } \\
\text { blasts }\end{array}$ & $\mathrm{M} \phi$ & $\mathrm{AEC}$ & VEC & $\begin{array}{l}\text { Lympho- } \\
\text { blasts }\end{array}$ & $\mathbf{M \phi}$ & $\mathrm{A} \mathbb{E C}$ & VEC \\
\hline 1 & -4 & -30 & 3 & 4 & - & - & - & - \\
\hline 2 & 89 & 70 & 77 & 89 & + & + & + & + \\
\hline 3 & 53 & 38 & 20 & 5 & + & + & + & - \\
\hline 4 & 26 & 7 & 72 & 30 & + & - & + & + \\
\hline 5 & 61 & 33 & 37 & $10^{\circ}$ & + & + & + & $+c$ \\
\hline 6 & 86 & -5 & 49 & 68 & + & - & + & + \\
\hline 7 & 22 & 18 & 58 & 6 & + & + & + & - \\
\hline 8 & 70 & 13 & 100 & 47 & + & - & + & + \\
\hline 9 & 63 & 19 & 43 & 28 & + & + & + & + \\
\hline 10 & 50 & 53 & 83 & 27 & + & + & + & t. \\
\hline 11 & 23 & $15^{\circ}$ & -5 & -1 & + & $+c$ & - & - \\
\hline 12 & 0 & -8 & -3 & 17 & - & - & - & + \\
\hline $\mathbb{3}$ & 68 & 65 & 39 & 70 & + & + & + & + \\
\hline 14 & 23 & 0 & 34 & 4 & + & - & + & - \\
\hline
\end{tabular}

a: The percentage specific lysis was calculated as usual; percentage specific lysis = $\frac{\text { experimental }{ }^{51} \mathrm{Cr} \text {-release }- \text { mean spontaneous }{ }^{51} \mathrm{Cr} \text {-release }}{\text { maximal }{ }^{51} \mathrm{Cr} \text {-release - mean spontaneous }{ }^{31} \mathrm{Cr} \text {-release }} \times 100 \%$

b. Clones that resulted in a lysis exceeding mean spontaneous release plus three standard deviations were defined positive for lysis (+); clones that resulted in a lysis below that discrimination point were defined negative for lysis $(-)$. Discrimination values correspondend to respectively $9,17,15$ and $15 \%$.

: Clone 5 for VEC and clone 11 for M $M$ were designated positive because these clones showed on two consequent occasions high specific lysis exceeding mean spontaneous release t+ 3 s.d., whereas in this experiment cytotoxicity exceeded mean spantaneous release +1 s. $d$. 
sider on statistical grounds that the vast majority of the cell populations originated from one cell and were therefore clonally pure. Circumstancial evidence for clonal origin of the cell populations could also be derived from the observation that not one pattern of lysis of one or more target cells occurred in only one experiment (see Table 2).

Cell-mediated cytotoxicity of cloned CTL. To classify the cytotoxicity of the clones as positive or negative for the four different target cell types, the CTL-clones were tested for cytotoxicity against cells of the stimulator, i.e. PHA-blasts, M $\phi, A E C$ and VEC. Cytotoxicity against these four targets was assayed at the same time with equal numbers of CTL used for each target. This excluded the possibility of differences in cytotoxicity caused by different effector to target ratios or variations in cytotoxic capacity of the CTL during culture. At that same time PHA-blasts, unrelated to the stimulator, were included in the $\mathrm{CMC}$-assay to detect non-specific lysis. Non-specific lysis was not observed in the experiments.

In Table 1 data are given on the $\mathrm{CMC}$ of clones generated in experiment $\mathrm{I}$, a representative experiment from a series of three experiments. Discrimination between positive and negative lysis by the clones was based on ${ }^{51} \mathrm{Cr}$-release of the target cell exceeding mean spontaneous release and three standard deviations in at least 2 out of 3 repeated experiments. In the experiment shown in Table 1, the discrimination values of ${ }^{51} \mathrm{Cr}$-release for PHA-blasts, M $\phi, A E C$ and VEC correspondend to respectively $9 \%, 17 \%, 15 \%$ and $15 \%$ lysis. The clones that were classified positive for lysis resulted in a specific lysis of the target cells exceeding this value. Few exceptions were found on retesting of the clones. Clone nr 7 lost its cytotoxicity during further culturing after two similar measurements had been made. Clone $\mathrm{nr} 7$ showed during further culturing a decrease in cytotoxicity for AEC, whereas cytotoxicity for PHA-blasts and $\mathrm{M} \phi$ remained constant. Clone nr 5 and clone $\mathrm{nr} 11$ were classified positive for lysis for respectively VEC and $\mathrm{M} \phi$ despite the results of lysis shown in Table 1 . These clones showed cytolysis clearly exceeding the discrimination values in 2 out of 3 experiments.

Patterns of cell-mediated cytotoxicity. Of the one hundred clones obtained, $86 \mathrm{clo-}$ nes appeared to lyse one or more of the four targets PHA-blasts, M $\phi, A E C$ and VEC. The remaining 14 clones were not cytotoxic in the repeated assay for cytotoxicity with the four targets.

Cytotoxicity patterns of the 86 cytolytic clones are given in Table 2. PHA-blasts were lysed by 80 clones; apparently these types of clones recognized determinants present on lymphocytes. The remaining six cytolytic clones can be divided in four clones which lysed only M $\phi$ (pattern $G$ ) and two clones that lysed only VEC (pattern H). The determinants recognized by these clones are suggested to have a limited tissue distribution.

An essential part of the clones which lysed PHA-blasts, lysed all four targets $(n=21)$, suggestive for recognition of a widely distributed determinant (pattern A). Eleven clones lysed only PHA-blasts (pattern B) and 33 clones lysed besides PHAblasts also $\mathrm{M} \phi$ (pattern $\mathrm{C}$ ). These two types of clones suggested that clones were 
Tabel 2. Patterns of cell-mediated cytotoxicity of cloned CTL, generated in MLC, against lymphoblasts, monocytes, arterial and venous endothelial cells."

\begin{tabular}{|c|c|c|c|c|c|c|c|c|}
\hline \multirow[b]{2}{*}{ Patterns } & \multicolumn{4}{|c|}{ Lysisa of } & \multicolumn{4}{|c|}{ Number in } \\
\hline & $\begin{array}{l}\text { Lympho- } \\
\text { blasts }\end{array}$ & $M \phi$ & $\mathrm{AEC}$ & VEC & $\begin{array}{c}\text { Exp. } \\
\text { I }\end{array}$ & $\begin{array}{c}\text { Exp. } \\
\text { II. }\end{array}$ & $\begin{array}{l}\text { Exp. } \\
\text { III. }\end{array}$ & Total \\
\hline A & $t$ & + & + & + & 5 & 5 & 11 & 21 \\
\hline B & + & - & - & - & 1 & 0 & 10 & 11 \\
\hline $\mathrm{C}$ & + & 4 & - & - & 2 & 0 & 31 & 33 \\
\hline$D$ & p & - & + & - & $\mathbb{1}$ & 5 & 2 & 8 \\
\hline $\mathrm{E}$ & + & + & + & - & 1 & 2 & 0 & 3 \\
\hline$F$ & + & - & + & + & 2 & 2 & 0 & 4 \\
\hline 0 & - & + & - & - & 0 & 3 & 1 & 4 \\
\hline $\mathrm{H}$ & - & - & - & + & 1 & 0 & 1 & 2 \\
\hline I & - & - & - & - & . & 5 & 8 & 14 \\
\hline
\end{tabular}

a: CTL-clones were arbitrarily defined positive $(+)$ or negative $(-)$ for lysis to the criteria described in the text.

b. The number of clones with a specific pattern of lysis of the four target cells in three separ ate experiments and their totals, are given.

generated that lysed only lymphocytes or only leukocytes. The remaining 15 clones of the 80 clones that lysed PHA-blasts could be divided in 3 patterns of reactivity toward the four target cells. A greater part of these 15 clones lysed the targets PHAblasts and AEC ( $(n=8)$ (pattern D); a smaller part lysed three targets in two different patterns: three clones lysed PHA-blasts, $\mathrm{M} \phi$ and $\mathrm{AEC}$ (pattern E) and four clones lysed PHA-blasts and both AEC and VEC (pattern F).

The data showed that PHA-blasts were the most frequently lysed target by the generated clones: 80 clones lysed this target. Monocytes were lysed by 61 clones. The endothelial targets AEC and VEC were lysed less frequently: AEC were lysed by 36 clones and VEC were lysed by 27 clones.

\section{Discussion}

Formerly MHC-class I antigens were considered to be the major targets for alloreactive CTL. Nowadays it is known that besides MHC-class I antigens, MHC-class II antigens $(1,2)$ minor alloantigens (9), H-Y antigen (10) and the Epa-antigen (3), can serve as targets for CMC. The Epa-antigen was demonstrated to be present on murine epidermal cells (3), and on fibroblasts and macrophages (11). CTL against the Epa-antigen were demonstrated to cause skin lesions as seen in graft-versus-host disease (12).

We present data on the cytotoxicity of CTL-clones generated in MLC towards PHA-blasts, M $\phi, A E C$ and VEC. Our data show that a wide variety of CTL-clones with different specificities can arise in MLC. It must be stated that only a restricted 
number of patterns was observed. It is not yet known if this heterogenous population of CTL-clones recognizes $\mathrm{MHC}$-antigens or minor antigenic systems, we can only speculate on the determinants that are involved in lysis of the target cells.

The most abundant types of clones were those with recognition of pattern A, B and C. It can be hypothesized that clones of pattern A (lysis of all four targets) recognize an alloantigen present on all target cells. Clones of pattern B (lysis of PHA-blasts only) may recognize a 'lymphocyte antigen'. Clones of pattern $C$ (lysis of PHAblasts and $\mathbf{M} \phi$ ) might represent recognition of a 'leukocyte antigen'. Pattern $G$ and $\mathrm{H}$ are both patterns of lysis of only one target cell: pattern $\mathrm{G}$ being lysis of monocytes, and pattern $\mathrm{H}$ lysis of VEC It is unlikely that the E-M-like antigens, present on monocytes and endothelial cells (13) are involved in these recognition patterns. Taking into consideration possible quantitative differences in the antigen expression of E-M antigens on the target cells this cannot be totally excluded. It has been demonstrated that not all monocyte antigens appear to be expressed on renal vascular endothelium (14), and we suggest that this might play a role in the observed differences between target determinants on monocytes and endothelial cells. A recent suggestion (15) that not all endothelial antigens are expressed on monocytes, correlates with our observation of the specificity pattern of CTL-clones for only M $\phi$ or only VEC.

The pattern of lysis of only VEC by CTL clones generated in MLC was a remarkable finding. Obviously the stimulator cells, that include B and T lymphocytes, monocytes, granulocytes and platelets, presented antigens that are not recognized on PHA-blasts and $\mathrm{M} \phi$, but are recognized on VEC. Suggestions for the determinants recognized by the cytolytic clones in patterns $\mathrm{D}, \mathrm{E}$ and $\mathrm{F}$ are not readily available. The determinants recognized by these clones have a diverse expression on the four target cells. Differences in expression, qualitatively and/or quantitatively of MHCclass II or other antigens on the four cell types could be responsible for the observed different cytotoxicity patterns of the CTL-clones. This holds not only for the patterns $\mathrm{D}, \mathrm{E}$ and $\mathrm{F}$, but also for the other patterns.

Indications for such involvement have been previously obtained in cold target inhibition studies (5) and in lymphocyte stimulation studies (6) with PHA-blasts, AEC and VEC. Addition of unlabeled VEC to labeled PHA-blasts was found not to inhibit lysis of PHA-blasts. These cold target inhibition experiments suggested that AEC and PHA-blasts were recognized for lysis by CTL through identical determinants, whereas VEC and PHA-blasts were not. The cytolytic patterns $C$ and D are in accordance with these earlier observations: in both patterns lysis of PHA blasts and AEC could be observed without lysis of VEC.

Lymphocyte stimulation with endothelial cells demonstrated that AEC and VEC are different cells in regard to the CTL that are generated: VEC as stimulator generated CTL toward PHA-blasts, AEC and VEC; and AEC generated CTL toward PHAblasts and AEC only. CTL generated with AEC as stimulator cells probably recognize a determinant that is inadequately expressed on VEC. A subpopulation of CTL from MLC might be able to recognize a similar determinant, which due to inade- 
quate expression on VEC cannot be detected by cold target inhibition studies. Such a putative determinant could be involved in pattern $F$, which consists of lysis of PHA-blasts, AEC and VEC.

Our data suggest that certain cell types have their own alloantigenic system and that quantitative differences in expression exist for more widely distributed alloantigens, recognized by CTL. It has been demonstrated with serological techniques that human granulocytes, monocytes and endothelial cells express antigens whose distribution is limited to these cells (16). The qualitative and quantitative differences in expression of such determinants which may be recognized by CTL may play a role in artificial immunological conditions, such as transplantation of bone marrow or vascularized organs, and in auto-immune disorders.

\section{Acknowledgements}

We gratefully acknowledge Mrs. A.J.J.M. Daemen and Mrs. E.E.M. Spronken for their technical assistance and Mrs. K. Spronck for her secretarial assistance. Dr. L. Strijbosch helped us with the statistical analysis of the data.

\section{Literature cited}

\section{Feighery C, Stastry P.}

HLA-D region-associated determinants serve as targets for human cell mediated lysis.

J. Exp. Med. 1979; 149: 485 .

2. Johnson HE, Mossin $J$, Madsen M, Krüstensen T, Kissmeyer-Nielsen F.

Human B-blast specific determinants in CML: a family study.

Tissue Antigens 1982; 19:222.

3. Steinmuller D, Tyler JD, David CS.

Cell-mediated cytotoxicity to non-MHC allo-antigens on mouse epidermal cells. 1 . H-2 restricted reactions among strains sharing the $\mathrm{H}-2^{k}$ haplotype.

I. Immunol. 1981; 126:1747.

4. Vegt PA, Buurman WA, vd Linden CJ, Daemen AJJM, Greep JM, Jeekel J.

Cellimediated cytotoxicity towards canine kidney epithelial cells.

Transplantation 1982; 33:465.

5. Groenewegen $G$, Buurman WA, vd Linden $C J$, Jeunhomme GMAA, Kootstra $G$.

Cellular cytotoxicity against canine endothelial cells. Analysis of determinants recognized by CTL.

Tissue Antigens 1983; 21: 114 .

6. Groenewegen $G$, Buarman WA, Jeunhomme GMAA, wd Linden $C J$, Vegt PA, Kootstra $G$.

In vitro stimulation of lymphocytes by vascular endothelial cells. A study with canine arterial and venous endothelial cells.

Transplantation 1984; 37, 206 .

7. Rinehart JJ, Gormus BJ, Lange P, Kaplan ME.

A new method for isolation of human monocytes.

J. Immunol. Methods 1978; 23: 207.

8. Bach $\mathrm{F}$.

On getting a T-cell and being assured you have one.

Immunol. Today $1983 ; 4: 243$.

9. Zier KS, Elkins WL, Pierson GR.

Cytotoxic $\mathrm{T}$ lymphocyte lines (CTL) against a human minor alloantigen.

Immunogenetics 1982; 15: 501. 
10. Goulmy $\mathrm{E}$, van Leeuwen $\mathrm{A}$, Blokland $\mathrm{E}$, van Rood $\mathrm{JJ}$, Budison WE.

Major histocompatibility complex-restricted $\mathrm{H}-\mathrm{Y}$-specific antibodies and cytotoxic $\mathrm{T}$ lymphocytes may recognize different self determinants.

J. Exp. Med. 1982;155, 1567.

11. Burlingham WJ, Tyler JD, Steinmuller $D$.

Cytotoxic $\mathrm{T}$ cells specific for epidermal allo-antigen, Epa-1, lyse allogeneic fibroblasts and macrophages in addition to epidermal cells.

Tramsplantation Proc. 1983; 15: 292.

12. Tyler JD, Steinmuller D, Galli SJ, Waddick KG.

Allospecific graft versus-host lesions mediated in MHC-restricted fashion by cloned cytolytic $\mathrm{T}$ lymphocytes.

Transplantation Proc. 1983; 15: 1441.

13. Moreas JR, Stastny $\mathbb{P}$.

A new antigen system expressed in human endothelial cells.

J. Clin. Invest. 1977; 60: 449.

14. Baldwin III WM, Claas FHJ, Paul LC, Springer TA, Hendriks GFd, van Es LA, wan Rood JJ. All monocytes are not expressed on renal endothelium.

Tissue Antigens 1983; 21: 254.

15. Paul LC, Busch GJ, Paradysz JM, Carpenter CB.

Definitions, genetics and possible significance of a newly defined endothelial antigen in the rat.

Transplantation $1983 ; 36: 533$.

16. Thompson JS, Overlin V, Seversen CD et al.

Determination of granulocyte, monocyte and endothelial cell antigens by double fluorochromatic microcytotoxicity testing.

Transplantation Proc. 1980; 12, suppl 1: 26. 

Lymphokines induce changes in morphology and enhance motility of endothelial cells

\section{Summary}

The influence of lymphokines, the soluble mediators produced by lymphocytes, on the morphology and the motility of endothelial cells in vitro is described. Lymphokines induced an altered morphology and an increased motility of canine and human venous endothelial cells. The action of the lymphokines was species specific. The data are discussed in relation to in vitro and in vivo data on the behaviour of endothelial cells in inflammation. The in vitro experiments allow further study of the role of endothelial cells in inflammatory and immunological processes. 
Angiogenesis demands proliferation of endothelial cells to cover the increased inner surface of the blood vessels, and migration of endothelial cells to the site to be newly supplied with blood vessels. Both in vivo and in vitro studies on these two aspects of angiogenesis have been reported (1-13). During arthritis, induced by intra-articular injections of horseradish peroxidase, endothelial proliferation was observed (1). Focal proliferation of endothelial cells in lymphnodes draining skin allograft during rejection resulted in arborization of high endothelial venules (2). Delayed type hypersensitiwity was found to increase endothelial cell proliferation (3) as did products of activated macrophages (4) and factors in wound fluid (5). In addition, thermal injury induced increased endothelial DNA-synthesis, at days 2 and 3 after injury and the formation of new blood vessels by days 5 to 7 (6).

The dependence of angiogenesis on circulating leukocytes was demonstrated in studies using total body irradiation (7). T-lymphocytes were demonstrated to be responsible for angiogenesis (8-10), and it was suggested that $T$-lymphocytes affected endothelial cells by a soluble mediator $(10,11)$. Such soluble mediators for intercellular communications produced by $T$-lymphocytes have been named lymphokines. Watt et al. (11) reported that culture supernatants from murine mixed lymphocyte culture contained both mitogenic and chemokinetic activity for bovine aortic and adrenal capillary endothelial cells. Other in vitro studies showed that human leukocyte interferon inhibits the migration of bovine capillary endothelial cells (12) and human lymphokine containing supernatants are reported to inhibit the motility of bovine aortic endothelial cells in an agarose microdroplet assay (13).

In summary, the in vivo studies (1-10) suggest proliferation and migration of endothelial cells to occur in inflammatory sites, and although separate phenomena, both are stimulated by lymphokines. The in vitro studies (11-13) showed different effects of lymphokines on endothelial motility in various experimental systems. We now report data on changes of morphology and motility of canine and human venous endothelial cells in a species specific response to lymphokines.

Materials and methods

Cultures of endothelial cells. Endothelial cells were obtained by collagenase-digestion of canine femoral veins; cells were culltured in Dulbecco's modified Minimal Essential Medium supplemented with $20 \%$ foetal calf serum (14). Endothelial cell cultures were started at nearly clonal density of cells and passaged at least 6 times before use in the experiments. Only cultures in which contamination with fibroblastoid and smooth muscle cells was excluded by frequent verification of the purity with an anti-canine F VIII related antigen reagent (15) and an anti-angiotensin converting enzym specific monoclonal antibody ( $\alpha$-ACE 3.1.1) (16) were used for the experiments. These reagents reacted in canine tissue sections specifically with endothelial cells. 
Human endothelial cells were obtained by collagenase treatment of veins obtained from young individuals. The endothelials were cultured as described by Thornton et al (17) in presence of heparin $(10 \mu \mathrm{g} / \mathrm{mi})$. Contamination with other cells than endothelial cells was excluded since cultures which contained cells not reacting with an anti-human F VIII reagent (15) and $\alpha$-AEC 3.1.1 (16) were ommitted from the experiments.

Production of lymphokine. Canine and human leukocytes were prepared from peripheral blood on density gradients. Canine lymphocytes and monocytes were separated by their properties of plastic non-adherence and adherence respectively. Canine allo-reactive $\mathrm{T}$ cell clones has been obtained as reported (18). Murine spleen cells of H-2 incompatible mice, C57BL and DBA, were prepared as usual.

Lymphokine containing supernatants were prepared in mixed leukocyte culture (MLC) by incubation of $10^{7}$ responder leukocytes/splenocytes and $5 \times 10^{4,}, 2500$ $\mathrm{rad} \mathrm{X}$-irradiated, stimulator leukocytes/splenocytes in $10 \mathrm{ml} \mathrm{RPMI} \mathrm{1640,} \mathrm{supple-}$ mented with $10 \%$ serum for 7 days. Proliferation and differentiation of cells in MLC were observed (data not shown). Monocyte supernatant was prepared by incubation of monocytes for 7 days in RPMI supplemented with 10\% serum. Supernatants of MLC, monocytes and CTL-clones were centrifuged and filtered (pore size $0.22 \mu \mathrm{m}$ ) to remove cells and cell remnants. All supernatants have been tested in dilutions up to 1:64. Recombinant human Interleukin 2 (Il-2) (19) and recombinant human gamma-interferon (INF- $\gamma$ ) (20) were used in concentrations of respectively $0-0.5 \mu \mathrm{g} / \mathrm{ml}$ and $0-2 \times 10^{4} \mathrm{U} / \mathrm{ml}$. Fresh medium with serum was always included as appropriate control for the effect of lymphokine.

Study on morphology and motility. The endothelial cells were cultured on gelatincoated object glasses in Bellco tissue culture chambers and incubated with the supernatants. For photography the cells were covered with a coverslip and sealed with paraffin and inspected with a microscope under phase contrast.

Morphology of endothelial cells was studied in confluent monolayers grown on a gelatin-coated surface; motility was studied with endorhelial cells seeded in low density on a gelatin-coated surface and recorded with time-lapse microphotography in a climate room at $37^{\circ} \mathrm{C}$.

\section{Results}

We observed the first indications for influence of lymphokines on the behaviour of endothelial cells in culture in mixed leukocyte endothelial cell cultures (MLEC) (21). The appearance of the endothelial cells changed markedly within $4 \mathrm{hr}$ after the addition of allogeneic lymphocytes to the endothelial monolayer. The normal appearance in culture of closely apposed nonoverlapping elongated cells changed, the cells became spindleshaped crossing over and under other cells, quite similar to the configuration of fibroblasts in culture. The cells no longer completely covered the surfa$c e$, as they did before the addition of the lymphocytes. We hypothesized that this change in morphology was mediated by lymphokines produced by the added lym- 
fig. 1

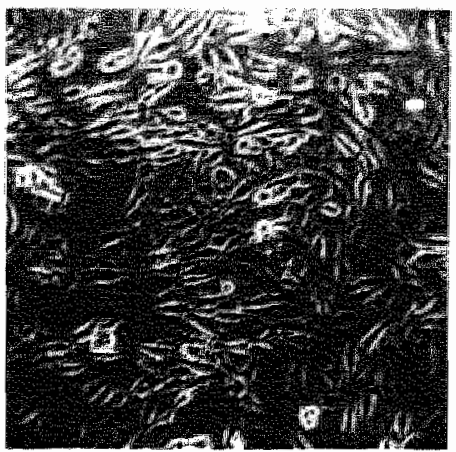

fig la

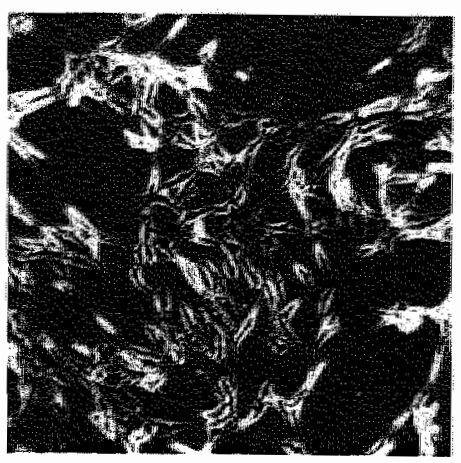

lig. Ib

Appearance of camine venous cultured endothelial cells (phase contrast, magnification $\pm 400 x$ )

A: appearance during culture in standard tissue culture medium

B: appearawce of endothelial cells with altered or "fibroblastoid" morphology induced by incubation for $6 \mathrm{hr}$ in canine LCS at a concentration of $10 \%$.

In A the encloihelial cells appear as closely apposed, slightly elongated cells. In B the morphology of the endothelial cells changed to a spindle shape with processes, which make contact with other cells. The surface is clearly less covered in $B$ than in $A$.

phocytes. We investigated this by analyzing the effects of cell-free supernatants of lymphocytes on endothelial cells. Such cell-free supernatants are called lymphokine containing supernatant (LCS).

LCS from various sources and species were tested for their ability to induce the changes in the morphology of endothelial cells to the same 'fibroblastoid' morphology as observed in MLEC. Cell-free supernatants were tested on confluent monolayers of canine and human cultured venous endothelial cells. The endothelial cells were inspected during incubation with the supernatant by phase-contrast microscopy. The 'fibroblastoid' mor phology of endothelial cells induced by lymphokine containing supernatant is shown in Fig. $1+2$. Results of a series of experiments are given in Table I. In MLC A/B* the responder lymphocytes $\mathrm{A}$ were activated and therefore proliferated in response to the alloantigens of irradiated stimulator lymphocytes $\mathrm{B}^{*}$. In MLC A*/B* the lymphocytes activated each other, but could not proliferate due to irradiation. In MLC $\mathrm{A} / \mathrm{A}^{*}$ there was no antigenic stimulus for activation and proliferation. LCS of a) activated and proliferating (MLC A/B*), b) activated non-proliferating (MLC $\mathrm{A}^{*} / \mathrm{B}^{*}$ ) and c) non-activated nonproliferating (MLC A/A*) canine lymphocytes induced the 'fibroblastoid' morphology when tested on canine venous endothelial cells. LCS produced by human cells affected the human venous endothelial cells whereas the canine cells were not affected. LCS of cytotoxic $T$ cell clones also induced the altered morphology in a species specific way. Human recombinant lymphokines, IFN- $\gamma$ and $11-2$, af fected neither human endothelial nor canine endothelial cells. Canine leukocytes were separated into monocytes and lymphocytes to study the effects of the soluble mediators produced by these subsets. Mediators from monocytes, monokines, did not influence the morphology 
Table I Effects of LCS on endothelial cell morphology and motility.

\begin{tabular}{|c|c|c|c|c|c|}
\hline \multirow[b]{2}{*}{ Source of supernatant } & \multicolumn{2}{|c|}{$\begin{array}{l}\text { Induction of } \\
\text { "fibroblastoid' } \\
\text { morphology }\end{array}$} & \multicolumn{2}{|c|}{$\begin{array}{l}\text { Induction of } \\
\text { increased } \\
\text { motility }\end{array}$} & \multirow[t]{2}{*}{$\begin{array}{l}\text { Number of } \\
\text { supernatants } \\
\text { tested }\end{array}$} \\
\hline & $\begin{array}{l}\text { Camine } \\
\text { endow } \\
\text { thelium }\end{array}$ & $\begin{array}{l}\text { Human } \\
\text { endo- } \\
\text { thelium }\end{array}$ & $\begin{array}{l}\text { Canine } \\
\text { endo- } \\
\text { thelium }\end{array}$ & $\begin{array}{l}\text { Human } \\
\text { endo- } \\
\text { thelium }\end{array}$ & \\
\hline canine $\mathrm{MLC} A / \mathrm{B}^{*}$ & + & - & + & - & 12 \\
\hline canine $\mathrm{MLC} \mathrm{A}^{*} / \mathrm{B}^{*}$ & + & - & + & - & 5 \\
\hline canine $\mathrm{MLC} A / \mathrm{A}^{*}$ & + & - & + & - & 4 \\
\hline $\begin{array}{l}\text { canine cytotoxic } \\
\mathrm{T} \text { cell clones }\end{array}$ & + & - & + & - & 6 \\
\hline canine monocytes & - & - & - & - & 3 \\
\hline human MLC A/B* & - & + & - & + & 4 \\
\hline $\begin{array}{l}\text { human cytotoxic } \\
\mathrm{T} \text { cell clone }\end{array}$ & - & + & - & + & 7 \\
\hline r-human $\gamma$-interferon & - & - & - & - & 1 \\
\hline r-human $11-2$ & - & - & - & - & 1 \\
\hline murine MLC A/B* & - & - & - & - & 3 \\
\hline murine EL4 thymoma & - & - & - & - & 3 \\
\hline
\end{tabular}

The experiments summarized above were executed with 9 different primary canine venous endothelial cell cultures and 4 primary human venous endothelial cell cultures produced in our laboratory. Morphology of endothelial cells was studied in confluent monolayers grown on a gelatin-coated surface; motility was studied with endothelial cells seeded in low density on a gelatin-coated surface and recorded with timelapse microphotography.

of the endothelial cells, while the lymphocyte produced mediators, lymphokines, induced the 'fibroblastoid' morphology as seen above. Although LCS of both stimulated and non-stimulated lymphocytes induced this 'fibroblastoid' morphology, LCS of activated, proliferating lymphocytes could always be diluted at least $64 \mathrm{x}$ times whereas LCS of unstimulated lymphocytes was only active up to dilutions of 1/4. The murine LCS of MLC A/B* and the murine thymoma EL4 did not produce a soluble mediator responsible for the 'fibroblastoid" morphology of canine and hu" man endothelial cells, which confirm in the species specificity reported above.

The change in endothelial cell morphology could be observed as early as $1 \mathrm{hr}$ after the addition of the LCS with maximal change after 4-6 hr. To exclude possibly cytotoxic effects of LCS as the cause for the change in morphology, the cultures were rinsed and LCS was replaced by fresh unconditioned medium. The endothelial cells reverted to their original morphology $4-6 \mathrm{hr}$ after the replacement of LCS by fresh medium.

The LCS was also tested for influence on the motility of endothelial cells (Table I). A strong increase in motility of the endothelial cells could be observed during the 


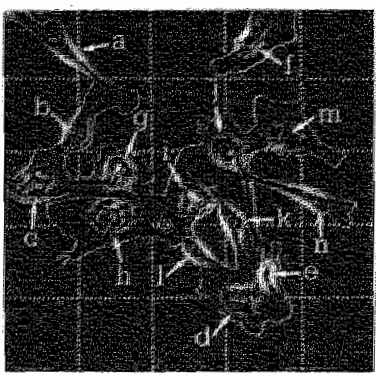

thme: $0 \mathrm{~min}$.

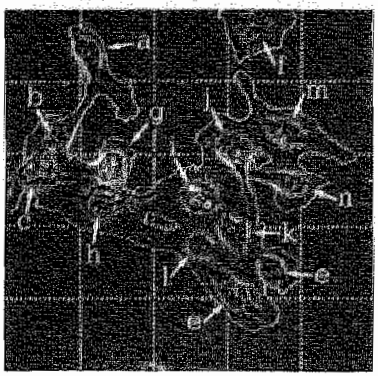

time: $120 \mathrm{~min}$

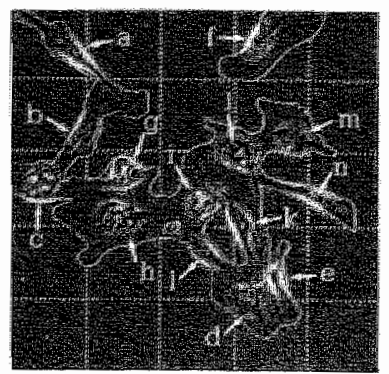

lime: $10 \mathrm{~min}$.

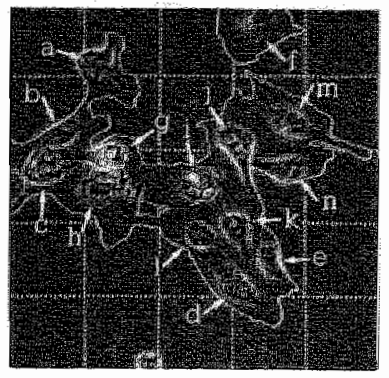

time: $175 \mathrm{~min}$

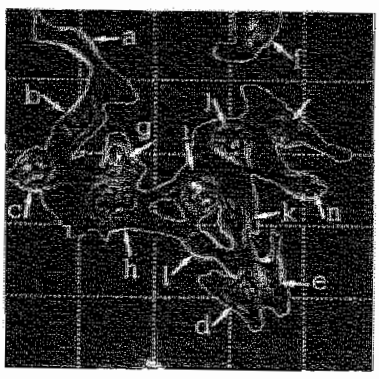

thre: $60 \mathrm{~min}$

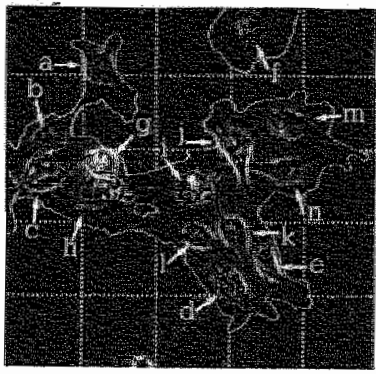

time: 205 min

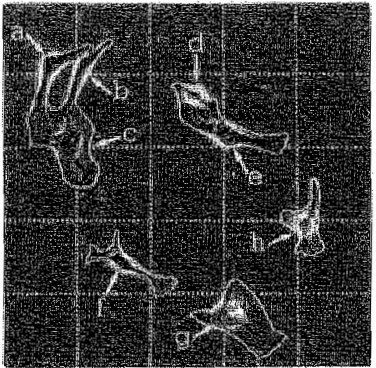

thme: $0 \mathrm{~min}$.

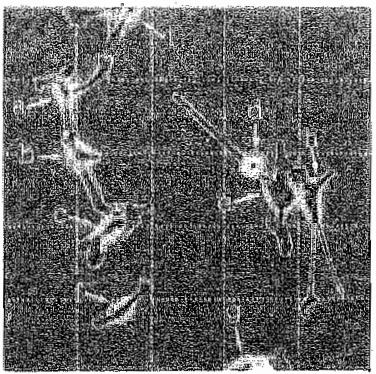

time: $180 \mathrm{~mm}$

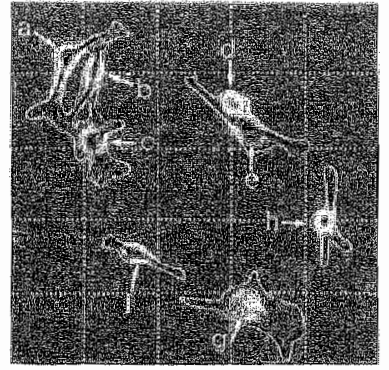

tume $60 \mathrm{~min}$

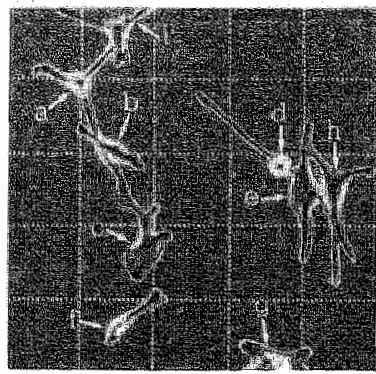

time: $240 \mathrm{~min}$.

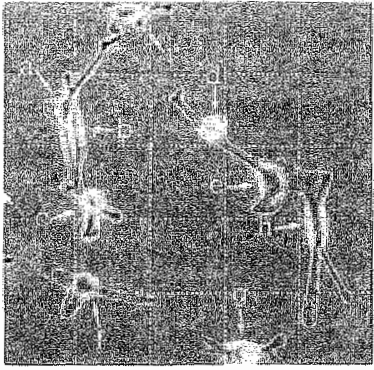

ume: $120 \mathrm{~min}$

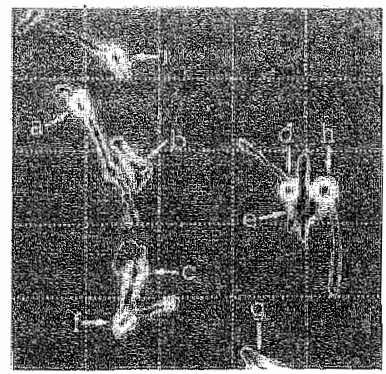

time $340 \mathrm{~min}$.

Motility of cultured venous endothelial cells in standard tissue cultwre medium (upper half) and in (ywphokine containing supernatant (lower half). Cells has been labeled to allow recognition of specific cells after movement. Time is indicated from start of experiment. Magnification: $\pm 400 x$.

In motility experiments the endothelial cells were seeded in low density in order to facilitate observation of motility.

Endorhelial cells in standard tissue culture medium show little motility. Lymphokine contai- 
incubation of the endothelial cells in LCS. For these experiments endothelial cells were seeded in low density on a gelatin-coated surface and cultured for one day after which LCS was added. To record the motility of a cell or group of cells time-lapse microphotography was performed with a microscope in a room at $37^{\circ} \mathrm{C}$. Photographs were taken every 5 to 10 minutes. A series of representative photographs of canine endothelial cells incubated in LCS in such an experiment is shown in Fig. 2, together with a series of photographs of canine endothelial cells in fresh medium. In absence of LCS endothelial cells showed little or no motility and no change in morphology. The canine LCS only induced motility of the canine endothelial cells whereas motility of the human endothelial cells was only induced by the human LCS. Murine LCS did not induce motility of either canine or human endothelial cells. The recombinant human IFN- $\gamma$ and Il-2 did also not induce motility. The motility of the endothelial cells returned to normal after the change of medium and was indistinguishable from motility of cells not incubated in LCS.

\section{Discussion}

It appeared that cell-free supernatants of lymphocytes induce a 'fibroblastoid' morphology of endothelial cells and an increased motility of endothelial cells. The lymphokine involved appears to be species specific. Obviously this is an opportunity to explain the data reported earlier $(12,13)$, which described that human lymphokines did not enhance motility of bovine endothelial cells, but rather inhibited their motility. As both the change in morphology and the increased motility are aspects of angiogenesis in vivo, we hypothesize that the lymphokine(s) detected in these experiments may be identical to those in vivo involved in angiogenesis at inflammatory sites. It is surprising that these effects, which take mainly place in capillaries and to a lesser extent in venules can be detected in culture with venous endothelial cells. The effects described are similar to the tumor-endothelium relationship regarding angiogenesis: growing tumors secrete angiogenetic factors that induce migration of endothelial cells (22) and proliferation of endothelium (23).

Earlier, in vitro experiments on changes in morphology and motility of endothelial cells were reported (11,24-26). A similar change in morphology as reported here was described briefly by Pober et al. $(24,25)$ for human umbilical vein endothelial cells (HUVE) on the addition of PHA to primary cultures. It is suggested that this effect was due to contaminating lymphocytes in the endothelial culture. Recently, Montesano et al. (26) reported that supernatants of PHA-stimulated lymphocytes induce HUVE to produce a highly organized, glycosaminoglycan-rich pericellular matrix. Marked morphological changes of the endothelial cells were observed, similar to the changes reported here. Addition of PHA to HUVE did not induce such morphological changes confirming the suggestion on contaminating lymphocytes above. The difference in species specificity shown in an earlier report (11) and our results may be due to different types of endothelium (aortic and capillary versus venous) or species of origin (bovine versus canine and human). Our data on change in morphology 
and increased motility of endothelial cells, induced by lymphokine are in accordance with in vivo findings in inflammatory reactions. The experimental system used here provides opportunities to study the role of endothelium in inflammatory reactions. The presentation of antigen (27) and of alloantigen (28) by endothelial cells in vitro demonstrates the role of endothelial cells in the centre of the immune response. The induction of 'Ja'-antigens on cultured endothelial cells by lymphokines $(24,25)$ and the expression of 'Ia'antigens on endothelial cells during skin-allograft rejection (29) demonstrate the influence of lymphokines produced in an inflammatory reaction on the behaviour of endothelial cells. The nature of the lymphokine or lymphokines responsible for induction of enhanced motility and 'fibroblastoid' morphology is sofar unknown. The data show that the factor involved is not identical with the $T$ lymphocyte growth factor Il-2 and not with IFN- $\gamma$. A lymphocyte derived factor has been reported to be specific chemotactic for human dermal fibroblasts. This factor with a Mol wt of 22,000 was shown to be different from the lymphokine that is chemotactic for monocytes and macrophages (30). Maturation and proliferation of astroglia and oligodendroglia cells in response to human lymphokines (Mol wt $6,000-10,000$ ) was recently reported (31). These reports indlicate that different lymphokines are responsible for the activation of fibroblasts and astroglia and oligodendroglia.

The nature of the species specific lymphokine responsible for induction of the change in morphology and enhanced motility of endothelial cells, which we hyphothesize to be involved in in vivo angiogenesis in inflammatory reactions, remains to be elucidated.

\section{Acknowledgements}

Mrs. G.M.A.A. Jeunhomme and Mrs. A.J.J.M. Daemen for their technical assistance and Mrs. K. Spronck for her secretarial assistance are kindly acknowledged. Dr. B.N. Bouma (University of Utrecht, Utrecht, The Nether lands) gave us an antiserum against canine F VIII related antigen and Dr. R. Auerbach (University of Wisconsin, Madison, WI) provided the monoclonal antibody reactive with angiotensin-converting enzyme ( $\alpha$-ACE 3.1.1.). Dr. R. Devos (Biogen, Gent, Belgium) is greatfully acknowledged for the gift of recombinant IFN- $\gamma$ and Il-2. Financial support was received from Nier Stichting Nederland (Dutch Kidney Foundation) with grant No. C 81.297 and from Fungo grant No 29.57.10.

\section{Literature cited}

1. Grahan $\mathrm{RC}_{*}$ Shannon SL.

Peroxidase arthritis. II Lymphoid cell-endothelial interaction during a developing immunological inflammatory response.

Am J Path 1972; 69: 7.

2. Anderson $\mathrm{ND}$, Anderson $\mathrm{AO}_{0}$ willie $\mathrm{RG}$.

Microvascular changes in lymph nodes draining skin allografts. 
Am J Path 1975; 81: 131.

3. Polverini PJ, Cotran RS, Sholley MM.

Endothelial proliferation in the delayed hypersensitivity reaction: an antoradiographic study.

J Immunol 1977; 118: 529.

4. Polverini PJ, Cotran RS, Gimbrone MA, Unanue ER.

Activated macrophages induce vascular proliferation.

Nature 1977; 269: 804 .

5. Banda MJ, Knighton DR, Hunt TK, Werb $Z$.

Isolation of a nonmitogenic angiogenesis factor from wound fluid.

Proc Natl Acad Sci USA 1982; 79: 7773.

6. Sholley MM, Cavallo T, Cotran RS.

Endothelial proliferation in inflammation. I Autoradiographic studlies following thermal injury to the skin of normal rats.

Am I Path 1977; 89: 277.

7. Fromer CH, Klintworth GK.

An evaluation of the role of leukocytes in the pathogenesis of experimentally induced corneal vascularization. II Studies on the effect of leukocytic elimination on corneal vascularization.

Am J Path 1975; 81: 531 .

8. Sidky $\mathrm{YA}_{\mathrm{A}}$ Auerbach $\mathrm{R}$.

Lymphocyte-induced angiogenesis: a quantitative and sensitive assay of the graft-ws-host reaction.

J Exp Med 1975; $141: \mathbb{1 0 8 4 .}$

9. Pliskin ME.

Activated lymphoid cells induce vascularization.

Transplantation 1979; $27 ; 136$.

10. Auerbach R, Sidky YA.

Nature of the stimulus leading to lymphocyte-induced angiogenesis.

J Immunol 1979; 123: 751.

11. Wati SC, Kirchmayer DA, Auerbach R.

In 'Interleukins, lymphokimes and cytokines' (JJ Oppenheim and S Cohen eds) p 317, Academic

Press, New York, 1983.

12. Brouty-Boyế D, Zetter BR.

Inhibition of cell motility by interferon.

Seience 1980; 208: 516.

13. Cohen MC, Picciano PT, Douglas WJ, Yoshida T, Kreutzer DL, Cohen S,

Migration inhibition of endothelial cells by lymphokine-containing supernatants.

Science 1982; $215: 301$.

14. Groenewegen G, Buurman WA, van der Linden CJ, Jeunhomme GMAA, Kootstra G.

Cellular cytotoxicity against canine endothelial cells. Analysis of determinants recognized by CTL.

Tissue Antigens 1983; 21: 114.

15. Hoyer LW, de los Santes RP, Hoyes JR.

Antihemophilie factor antigens: localization in endothelial cells by immunofluorescence microscopy,

$J$ Clin Invest $1973 ; 52: 2737$.

16. Auerbach $R$, Alby L, Grieves J, Joseph J, Lindgren C, Morrisey LW, Sidky YA, Tu M, Watt SL. Monoclonal antibody against angiotensin-converting enzyme: its use as a marker for murine, bovine and human endothelial cells.

Proc Natl Acad Sci USA 1982; 79: 7891.

17. Thornton SC, Mueller SN, Levine EM.

Humar endothelial cells: use of heparin in cloning and longterm serial cultivations.

Science $1983 ; 222: 623$.

18. Groenewegen $G$, Buurman WA, van der Linden $C J$, Jeunhomme GMAA, Kootstra $G$.

Cell-mediated cytotoxicity patterns of cloned cytotoxic T lymphocytes. Cytotoxicity directed against canine lymphoblasts, monocytes and endothelial cells.

Transplantation, in press.

19. Devos R, Plaetinck G, Cheroutre H, Simons G, Degrave W, Tavernier J, Remaut E, Fiers W. Molecular cloning of human immune interferon with DNA and its expression in eukaryotic cells.

Nucl Acids Res 1983; 11: 4307 .

20. Scahill $S$, Devos $R$, van der Heyden J, Fiers $W$. 
Expression and characterization of the product of a thuman immune interferon DNA gene in Chinese hamster ovary cells.

Proe Nall Acad Sci USA 1983; 80, 4654.

21. Groenewegen G, Buurman WA, Jeunhomme GMAA, van der Linden CJ, Vegt PA, Kootstra $\mathrm{G}$. In witro stimulation of lymphocytes by vascular endothelial cells. A study with canine arterial and venous endothelial cells.

Transplantation 1984; 37: 206 .

22. Zetter BR.

Migration of capillary endothelial cells is stimulated by tumor-derived factors.

Nature $1980 ; 285: 41$.

23. Folkman J, Merler E, Abernathy C, Williams $G$.

Isolation of a tumor factor responsible for angiogenesis.

J Exp Med 1971; 133: 275.

24. Pober JS, Gimbrone MA.

Expression of la-like antigens by human vascular endothelial cells is inducible in vitro: demonstration by monoclonal antibody binding and immunoprecipitation.

Proc Natl Acad Sci USA 1982; 79: 6641.

25. Pober JS, Gimbrone MA, Cotran RS, Reiss CS, Burakoff SJ, Fiers W, Ault KA.

la expression by vascular endothelium is inducible by activated $T$ cells and by human gamma interferon.

J Exp Med 1983; 157: 1339:

26. Montesano R, Mossaz A, Ryser J-E, Orcil L, Vassalli P.

Leukocyte interleukins induce cultured endothelial cells to produce a highlly organized, glycosaminoglycan-rich pericellular matrix.

J Cell Biol 1984; 99: 706.

27. Hirschberg H, Bergh OJ, Thorsby $\mathrm{E}$.

Antigen presenting properties of human vascular endothelial cells.

J Exp Med 1980; 152: 249S.

28. Groenewegen $G$, Buurman WA.

Vascular endothelial cells present alloantigens to unprimed lymphocytes.

Scand J Immunol 1984; 19: 269.

29. de Waal RMW, Bogman MJJ, Maass CN, Cornelissen LMH, Tax WJM, Koene RAP. Variable expression of la antigens on the vascular endothelium of mouse skin allografts. Nature 1983; 303: 426 .

30. Postletluwaite AE, Snyderman RS, Kang AL.

The chemotactic attraction of human fibroblasts to a lymphocyte-derived factor.

J Exp Med 1976; 144: 1188.

31. Merrill IE, Kutsunai $S_{w}$ Mohlstrom $C_{3}$ Hofman F, Groopman J, Golde DW.

Proliferation of astroglia and oligodendroglia in response to human $\mathrm{T}$ cell-derived factors.

Science 1984; 224: 1.428. 


\section{CHAPTER 6}

In vitro stimulation of lymphocytes by vascular endothelial cells.

A study with canine arterial and venous endothelial cells.

\section{Summary}

Data are presented on the stimulating capacity of arterial and venous endothelial cells to allogeneic leukocytes. Mixed cultures of allogeneic endothelium and lymphocytes result in proliferation of lymphocytes and generation of cell-mediated cytotoxicity, which are absent in cultures of syngeneic combinations of endothelium and lymphocytes. Studies on kinetics showed a peak in proliferation at day 6-7. Optimal responder-stimulator ratio appeared to be $15: 1$. Lymphocytes stimulated with venous endothelial cells were cytotoxic for both arterial and venous endothelial cells and PHA-blasts of the stimulator dog, whereas lymphocytes stimulated with arterial endothelial cells lysed only arterial endothelial cells and PHA-blasts of the stimulator. Lysis of syngeneic or third party allogeneic control targets was virtually absent. Optimal conditions for long term culture of effector cells from MLEC were analysed. Addition of I1-2 every 3 days and the original stimulating antigen every 6 days permitted continuous proliferation of these cytotoxic lymphocytes with preservation of the cytotoxicity pattern. 
Endothelium is the first tissue encountered by the recipient's immune system in vascularized allografts. In a recipient with an unmodified immune system differences in antigens between donor and recipient will provoke the process of rejection. Though it is known that complete identity in regard to antigens prevents rejection, both experimental and clinical transplantation have not elucidated which antigens have to be identical. Our study has been aimed to detect antigens on endothelium which provoke an immune response and eventually rejection.

The process of cell-mediated cytotoxicity (CMC) has been divided in an afferent phase of antigen-recognition and subsequent expansion of effector cell population, and an efferent phase of destruction of cells carrying the antigens recognized in the afferent phase. Several cell types have been reported to initiate the afferent phase in vitro, that is they have a stimulating capacity for allogeneic lymphocytes. Lymphocyte stimulation has been reported for canine $(1,2,3)$ and rat $(4,5)$ kidney cells, human $(6)$, rat $(7,8)$ and murine $(9,10)$ epidermal cells and human $(11)$ and canine (12) endothelial cells. Less attention has been paid to the efferent phase of CMC against these nonlymphoid stimulating cells. Reports are limited to murine epidermal cells $(9,10)$ and cultured canine kidney cells $(2,13)$. CMC against endothelial cells in vitro can be generated in mixed lymphocytes cultures (MLC) (14,15), indicating a role for endothelial cells in rejection. In a previous report (15) we described a difference in antigens on arterial and venous endothelial cells in dogs recognized by cytotoxic T lymphocytes (CTL) generated in MLC. We suggested arterial endothelial cells to be recognized for lysis through MHC-class I antigens, and venous endothelial cells to be recognized for lysis through MHC-class II or EM antigens. This difference in antigens recognized on arterial endothelial cells and venous endothelial cells necessitated the analysis of antigens recognized on endothelial cells in the afferent phase of $\mathrm{CMC}$.

In this report we present data on the stimulating capacity of both cultured arterial and venous endothelial cells to allogeneic lymphocytes and on the efferent phase of cellmediated cytotoxicity induced by these endothelial cells.

\section{Materials and Methods}

Endothelial cell culture. The isolation, culture and identification of both arterial and venous endothelial cells have been described before (15). In brief, common carotid artery and external jugular vein were removed unilaterally from dogs. Endothelial cells were released by collagenase treatment and cultured in gelatin-coated tissue culture flasks in Dulbecco's modified Minimal Essential Medium, supplemented with $20 \%$ heat inactivated foetal calf serum (FCS), penicillin and streptomycin. Cultured cells were identified as endothelial cells by their growth pattern in monolayers, their microscopical appearance and their positive immunofluorescence with an anticanine F VIII related antigen reagent. When cultures reached confluency, cells were 
released from culture flasks by protease-incubation and subcultured at a 1:3 or 1:4 ratio. Endothelial cells used in the experiments reported have been subcultured between 4 and 8 times.

Mixed leukocyte endothelial cell culture (MLEC). Leukocytes have been prepared by density centrifugation on Lymphoprep (Nyegaard, Oslo, Norway). Endothelial cells used as stimulator cells were released from culture flasks by incubation with Dispase grad II (Boehringer, Mannheim, FRG) and washed once in RPMI 1640 (Gibco Europe, Paisley, Scotland). Proliferation of endothelial cells was inhibited by 2500 rad X-irradiation. MLEC were performed in RPMI 1640 culture medium supplemented with $10 \%$ heat inactivated canine serum (30 min at $56 \mathrm{C}$ ) and 100 $\mathrm{IU} / \mathrm{ml}$ penicillin and $100 \mu \mathrm{g} / \mathrm{ml}$ streptomycin; this is referred to as complete RPMImedium. MLEC cultures were incubated at $38 \mathrm{C}$ in a water saturated atmosphere containing $5 \% \mathrm{CO}_{2}$ in air.

Mass cultures were performed in $50 \mathrm{ml}$ culture flasks (Greiner, Nürtingen, FRG), placed at an angle of $30^{\circ}$. Cultures consisted of $10^{7}$ leucocytes in $10 \mathrm{ml}$ complete RPMI-medium with an optimal number of stimulator endothelial cells (described the result-section). Microcultures were performed in 96 wells microtiter plates (Greiner, Nürtingen, FRG) with relevant numbers of responder and stimulator cells. Proliferation generated in MLEC was quantitated by ${ }^{3} \mathrm{H}$-TdR-incorporation during the final $4 \mathrm{~h}$ of culture. From mass cultures $10^{5}$ cells were assayed in quadruplicate in microtiterplates. Cells in microcultures were assayed directly. To each well $0.5 \mu \mathrm{Ci}{ }^{3} \mathrm{H}-\mathrm{TdR}$ (specific activity $5 \mathrm{Ci} / \mathrm{mMol}$ ), (Amersham, England) was added. Cells were harvested on glassfiber discs and counted for radio-activity in a scintillation counter.

Cell-mediated cytotoxicity. The assay of cell-mediated cytotoxicity (CMC) against endothelial cells has been described before (15). In brief, endothelial cells were released from culture flasks by $15 \mathrm{~min}$ incubation in $0.02 \%$ EDTA in PBS at 38C, washed twice, and subsequently labeled with $200 \mu \mathrm{Ci} \mathrm{Na}{ }^{51} \mathrm{CrO}_{4}$ (specific activity $350-600 \mathrm{mCi} / \mathrm{mg} \mathrm{Cr}$ ), (Amersham, England) for $45 \mathrm{~min}$ at $38 \mathrm{C}$ and washed three times in complete RPMI-medium. Target cells, $2.5 \times 10^{3}$, were incubated with varying numbers of effector cells from MLEC for $6 \mathrm{~h}$ at $38 \mathrm{C}$. Tests were performed in quadruplicate in microtiter plates. Cell free supernatants were harvested with supernatant harvesting cartridges (Skatron, Oslo, Norway) and counted for ${ }^{51} \mathrm{Cr}-\mathrm{con}$. tent. Spontaneous release was determined by incubation of target cells in complete RPMI-medium and ranged from $16 \%$ to $26 \%$, maximum release was determined by incubation with a detergent (Cetavlon) and always exceeded $85 \%$. Specific experimental ${ }^{5 i} \mathrm{Cr}$-release was calculated as usual (15).

In some experiments phytohaemagglutinin (PHA) stimulated lymphocytes have been used as targets for CMC. PHA-blasts have been prepared by stimulation of peripheral blood leukocytes with an optimal dose of PHA for 3 days in complete RPMI-medium.

Long term culture of effector cells. Long term culture of effector cells from MLEC was performed in $2 \mathrm{ml} 24$ cluster well plates (Costar, Cambridge, MA, USA) as 


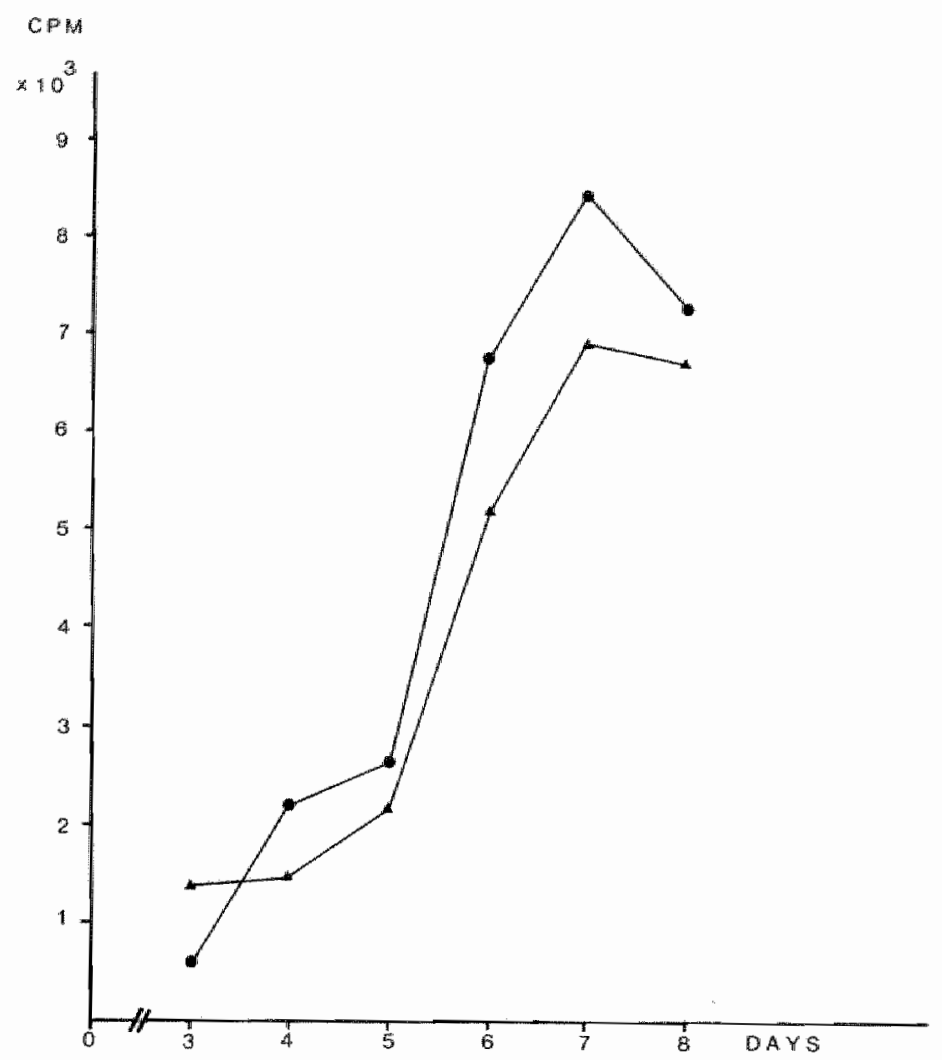

Figure 1. Kinetics of MLEC-response.

$1.5 \times 10^{5}$ lescocytes were cocultured with $10^{4}$ arterial endothetial cells ( 4 ) or $10^{4}$ venous endothelial cells (9).

Proliferation was measured by ${ }^{3} H-T d R$-incorporation on day 3 to day 8.

described in the text. $11-2$ containing supernatant was prepared by incubation of 2 $\times 10^{6}$ cells per $\mathrm{ml}$ of El-4 lymphoma cells of clone 6 (kindly provided by Dr. Cerottini, Switzerland) for $48 \mathrm{~h}$ with phorbol myristic acetate, $10 \mathrm{ng} / \mathrm{ml}$ (Sigma, St. Louis, MO, USA), and $1 \%(\mathrm{v} / \mathrm{v})$ canine serum. Supernatant was collected, centrifuged and filter sterilized. 11-2 content was assayed as described (16). El-4-supernatant was used in an optimal concentration for growth of $11-2$ dependent cells.

\section{Results}

Afferent phase of MLEC. Kinetics of MLEC response were determined by measurement of proliferation, ${ }^{3} \mathrm{H}$-TdR-incorporation, on consecutive days from day 3 to 8 of culture. Results of two representative experiments from a series of experiments are shown in Figure 1. Proliferation was maximal at day 6 to day 7, independently of responder-stimulator ratio used. A difference in kinetics of MLEC for arterial endothelial cells and venous endothelial cells was not observed. Optimal responder- 
Tabel 1. Proliferation of lymphocytes stimulated by venous endothelial cells at various responder-stimulator ratios. ${ }^{a, b}$

\begin{tabular}{cccccc}
\hline & \multicolumn{5}{c}{ Endothelial cells per well } \\
\cline { 2 - 6 } & $10^{5}$ & $5 \times 10^{4}$ & $10^{4}$ & $5 \times 10^{3}$ & $10^{3}$ \\
\hline $\begin{array}{c}\text { R:S ratio } \\
\text { Experiment }\end{array}$ & $1.5: 1$ & $3: 1$ & $15: 1$ & $30: 1$ & $150: 1$ \\
I & 1,315 & 2,510 & 4,758 & 4,270 & 3,141 \\
II & 2,072 & 1,456 & 3,544 & 2,897 & 1,541 \\
III & 1,713 & 5,115 & 3,611 & 2,058 & 2,253 \\
IV & ntc & 648 & 2,064 & 3,086 & 2,039 \\
\hline
\end{tabular}

a. In alle experiments $1.5 \times 10^{5}$ responder cells were used. Proliferation is expressed in counts per minute ${ }^{3} H-T d R$ incorporation.

b: For clarity the two highest values are in italics.

: nt: not tested.

Table 2. Cell-mediated cytotoxicity of lymphocytes stimulated in $M L E C^{a}$

\begin{tabular}{|c|c|c|c|c|c|c|c|}
\hline \multirow{2}{*}{$\begin{array}{l}\text { MLEC } \\
\text { responder/ } \\
\text { stimulator }\end{array}$} & \multirow{2}{*}{$\begin{array}{l}\text { Effector: } \\
\text { target } \\
\text { ratio }\end{array}$} & \multicolumn{3}{|c|}{ Stimulator targets ${ }^{\circ}$} & \multicolumn{3}{|c|}{ Control targets } \\
\hline & & $\mathrm{AEC}$ & VEC & PHA & $\mathrm{AEC}$ & VEC & PHA \\
\hline \multirow[t]{2}{*}{ 137/706 VEC } & 40:1 & 58 & 27 & 73 & 5 & 0 & 0 \\
\hline & $20: 1$ & 45 & 12 & 50 & & & \\
\hline \multirow[t]{2}{*}{$137 / 706 \mathrm{AEC}$} & 40:1 & 22 & 0 & 34 & 2 & 0 & 0 \\
\hline & $20: 1$ & 22 & 0 & 211 & 0 & 0 & 0 \\
\hline \multirow[t]{2}{*}{$138 / 706 \mathrm{VEC}$} & $40: 1$ & 32 & 33 & 41 & & 0 & 0 \\
\hline & $20: 1$ & 15 & 18 & 36 & & 0 & 0 \\
\hline \multirow{2}{*}{$170 / 212 \mathrm{AEC}$} & $40: 1$ & 15 & -1 & & & & \\
\hline & $20: 1$ & 14 & -3 & & & & \\
\hline \multirow[t]{2}{*}{$222 / 116$ VEC } & $40: 1$ & 58 & 28 & & & & \\
\hline & $20: 1$ & 37 & 14 & & & & \\
\hline \multirow[t]{2}{*}{$222 / 116 \mathrm{AEC}$} & $40: 1$ & 37 & 0 & & & & \\
\hline & $20: 1$ & $2 \mathbb{1}$ & 0 & & & & \\
\hline
\end{tabular}

a: percentage specific ${ }^{3 /} \mathrm{Cr}$-release is given.

b. a fixed number of $2.5 \times 10^{3}$ target cells has been used.

c: AEC: arterial endothelial cells.

$V E C$ : venous endothelial cells.

PHA: PHA-blasts.

The numbers $116,137,138,170,212,222$ and 706 represent individual dogs. 
stimulator ratio (R:S-ratio) for MLEC was determined by measurement of proliferation for different $\mathrm{R}: \mathrm{S}$-ratios at day 6 . Results are shown in Table 1 . The optimal $\mathrm{R}:$ S-ratio for proliferation of lymphocytes in MLEC ranged from 3:1 to 30:1 with a modal value of 15:1. A difference between arterial endothelial cells (data not given) and venous endothelial cells as stimulator cells was not found.

Efferent phase of MLEC. Based on the data concerning the kinetics and optimal responder-stimulator ratio, subsequent $\mathrm{MLEC}$ experiments were performed by coculturing $10^{6}$ lymphocytes per $\mathrm{ml}$ with $\mathrm{X}$-irradiated endothelial cells in a $\mathrm{R}: \mathrm{S}$ ratio of $10: 1$ or $20: 1$ for 7 or 8 days.

Leukocytes stimulated by endothelial cells were tested for cell-mediated cytotoxicity against endothelial cells in a ${ }^{51} \mathrm{Cr}$-release assay. Specificity of lysis by effector cells stimulated with allogeneic endothelial cells was tested by measurement of cytotoxicity on syngeneic or third party allogeneic cells to exclude non-specific lysis by effector cells. Lysis was not obserwed in such control experiments. Results of a number of experiments are shown in Table 2. Lymphocytes stimulated by allogeneic venous endothelial cells lysed the stimulating venous endothelial cell specifically, since syngeneic or third party allogeneic target cells were not lysed. Furthermore arterial endothelial cells and PHA-blasts of the same endothelial cell donor were lysed by lymphocytes stimulated by venous endothelial cells. Lysis of arterial endothelial cells, venous endothelial cells and PHA-blasts by lymphocytes stimulated with venous endothelial cells, ranged from $15-58 \%, 12-33 \%$ and $36-72 \%$ respectively.

Lymphocytes stimulated by allogeneic arterial endothelial cells appeared to lyse only arterial endothelial cells and PHA-blasts of the endothelial cell donor. Lysis of venous endothelial cells was virtually absent in all experiments. Lysis of arterial endothelial cells and PHA-blasts by lymphocytes stimulated with arterial endothelial cells ranged from $14-37 \%$ and $21-34 \%$ respectively, while lysis of venous endothelial cells in these experiments ranged from -3 to $0 \%$. Lymphocytes stimulated in MLEC by venous endothelial cells appear to differ in recognition of target-antigens for cytolysis from lymphocytes stimulated by arterial endothelial cells. It is concluded that arterial endothelial cells are uncapable to stimulate proliferation of lymphocytes that recognize and lyse venous endothelial cells. Proliferation and generation of cellmediated cytotoxicity were not observed in mixed cultures of lymphocytes and endothelial cells from the same dog (data not given).

Long term culture of effector cells from MLEC. Optimal conditions for long term culture of MLEC derived effector cells were analysed. Results of one of a series of experiments are shown in Figure 2, results of CMC-assays are given in Table 3. In this experiment cell numbers increased till day 28 of culture. The cells were cultured by addition of 11-2-containing supernatant every 3 days and addition of the original stimulating antigen every 6 days. Stimulating antigen was frequently added in order to retain specificity of lysis. CMC, tested on days 13,21 and 31 of culture, remained specifically against the stimulator cells. These long-term cultured effector cells, stimulated with endotheliall cells showed a cytotoxicity at a very low effector-target cell ratio. At day 31 lysis of stimulator cells was $25 \%$ at an effector-target cell ratio of 


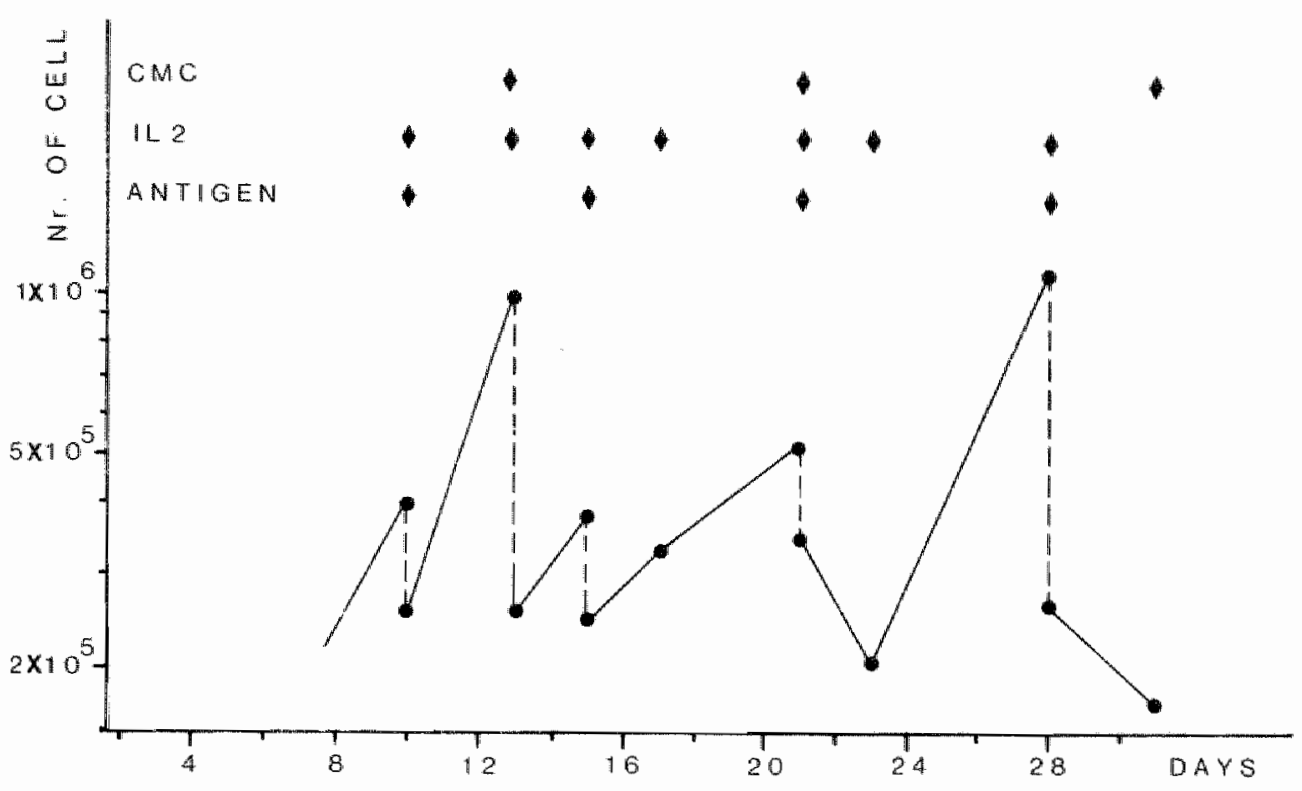

Figure 2. Proliferation of effector cells from MLEC in tongterm culture.

Leukocytes were stimulated with venous endothelial cells of dog nr. 275 (VEC 275) and kept in long term cuiture. Addition of IL-2 and/or VEC 275 is indicated. The cells were diluted to $2.5 \times 10^{5}$ cells/well, on days $10,13,15,21,28$, indicated by interrupted lines. Results of cell-mediated cytoroxicity assays are shown in Table 3.

3.2:1, without lysis of third party target. Sofar effector cells generated in MLEC have been cultured up to two months without loss of cytotoxicity or specificity of cytolysis.

\section{Discussion}

In a previous paper we postulated that in the efferent phase of cell-mediated cytotoxicity arterial endothelial cells are recognised by CTL through MHC-class I antigens, while venous endothelial cells are recognised through different antigens, possibly MHC-class II or E-M-antigens (15). In this report we present data on the analysis of determinants recognised in the afferent phase of cellular immunity against endothelium by in vitro stimulation of lymphocytes with arterial or venous endothelial cells. Both arterial and venous endothelial cells stimulate allogeneic lymphocytes to proliferation and differentiation. Stimulation was not observed in mixed cultures of lymphocytes and endothelial cells in syngeneic combinations.

Dendritic cells are known to be potent stimulators of allogeneic lymphocytes (17). However, it is unlikely that the proliferation of lymphocytes in MLEC is caused by dendritic cell contamination of the endothelial cell cultures. It has been reported that dendritic cells do not proliferate in vitro (18) and that canine dendritic cells are 
Table 3. Cell-mediated cytotoxicity of long term cultured effector cells from MLEC.

Day of culfure

Effector:

target ratio

Target cells $5^{b}$

VEC 275

day 13

16:1

36

day 21

$8: 1$

$4: 1$

$2: 1$

VEC 275

14

7

4

AEC 275

35

9

10

VEC 275

PHA 134

day 31

$6.4: 1$

$3.2: 1$

37

$-7$

25

Lymphocytes have been stimulated with venous endothelial cells of dog $m r .275$ (VEC 275).

a: percentage specific ${ }^{5 /} \mathrm{Cr}$ release is given.

b. AEC: arterial endothelial cells

VEC: venous endothelial cells

PHA: PHA-blasts

Dog 134 is unrelated to dog 275.

non adherent to plastic surfaces (19). The endothelial used in our experiments cells have been subcultured at least 4 times before the cells were used as stimulator cells, diluting possible dendritic cells left from the primary cultures to insignificant numbers. After collagenase treatment of bloodvessels, to obtain endothelial cells, only a small number of cells adhered and proliferated in culture. Thus the endothelial cells are from a oligoclonal origin. Cells with a dendritic morphology have not been observed by microscopy in the primary cultures and subcultures. Proliferation observed in MLEC must therefore be caused by stimulation of lymphocytes by arterial or venous endothelial cells. This is strongly supported by the observed differences in target cells lysed by cytotoxic $\mathrm{T}$ lymphocytes stimulated by arterial or by venous endothelial cells.

Kinetics of MLEC appeared to be similar to kinetics of MLC in dog (3). MLEC showed a peak in proliferation on day 6-7. Optimal responder:stimulator cell ratios in MLEC were 3:1 to $30: 1$ with a modus of $15: 1$. These ratios are different from R:Sratios in MLC and similar to R:S-ratios in mixed kidney cell lymphocyte cultures (MKLC) in dlog (3). A similar mechanism of inhibition of lymphocyte proliferation by the stimulating endothelial cells in MLEC or kidney cells in MKLC (13) might explain these high R:S-ratios. Lower proliferation in MLEC compared to MLC might be caused by prostaglandins, especially $\mathrm{PGE}_{2}$, produced by cultured endothelial cells. $\mathrm{PGE}_{2}$ is known to inhibit the production of Interleukin 2 (Il-2) by stimulated lymphocytes (20), while II-2 is necessary for the proliferation of these stimulated lymphocytes. 
Differences between arterial and venous endothelial cells as stimulator cells in MLEC have not been found for R:S-ratios and kinetics, suggesting an identical mechanism of lymphocyte reactions against arterial and venous endothelial cells.

Both arterial and venous endothelial cells used as stimulators in MLEC resulted in the generation of cell-mediated cytotoxicity specifically against stimulator antigens. Arterial endothelial cells and PHA-blasts are recognized by effector cells through identical determinants and venous endothelial cells are recognized through a different group of determinants (15). Effector cells stimulated with venous endothelial cells were found to lyse these three target cells, whereas effector cells stimulated with arterial endothelial cells lysed only arterial endothelial cells and PHA-blasts. An explanation for these experimental data might be a difference in antigens recognized in an afferent phase (stimulating antigens) and antigens recognized in an efferent phase (target antigens) of cell mediated cytotoxicity.

The fine specificity of target antigens recognized by a single lymphocyte can be analyzed by cloning of effector cells. Cloning of cytotoxic T lymphocytes will be necessary for the clarification of the antigens in an allograft which can be recognised by the recipient's immune system. Knowledge of the exact antigens is increasingly important, since it has been demonstrated in vitro that other cells than cells from leukocytic lineages can stimulate allogeneic lymphocytes, resulting in a tissue-specific reaction against stimulating cells $(9,13)$.

Long term culture of MLEC-derived effector cells is an obligatory part of cloning these cells. Effector cells from MLC in different species, e.g. human (21) and dog (22), can be kept in long term culture with exogenous II-2. Also effector cells of mixed cultures of murine splenocytes and tumor cells could be kept in long term culture (23). Here we report the culture conditions for the long term culture of effector cells from MLEC. These conditions appeared to be similar to the conditions for long term culture of canine MLC-derived cells (16). By addition of Il-2-containing supernatants every 3 days and addition of stimulating antigen, i.e. endothelial cells, every 6 days, MLEC-derived effector cells could be cultured for long periods, remaining specifically cytotoxic against the stimulating cells. The addition of accesory cells (24) appeared to be unnecessary. This might be explained by the presence of this accesory cell function in the stimulating cell population. Endothelial cells have been reported to have an antigen presenting function $(25,26$, Groenewegen unpublished data), possibly the essential function of an accesory cell.

Here we report the stimulating capacity of endothelial cells for allogeneic lymphocytes in dogs. Venous endothelial cells generated cytotoxicity against venous and arterial endothelial cells and PHA-blasts, while effector cells stimulated by arterial endothelial lysed only arterial endothelial cells and PHA-blasts. Effector cells from MLEC could be kept in long term culture with preservation of the specific cellmediated cytotoxicity, which permits cloning of these effector cells. Cloning by limiting dilution techniques will be used to analyze the qualitative and quantitative aspects of the antigens recognized by cytotoxic $T$ lymphocyte precursors on endothelium from different sources. 
The authors wish to thank Mrs. A.J.J.M. Daemen for her technical assistance and Mrs. K. Spronck for her secretarial assistance.

\section{Literature cited}

1. Lifton $\mathrm{J}$, de Wolf WC, Wilcox $\mathrm{C}$, Miller $\mathrm{J}$. The primed camine MLC $t$ allograft immunity in vitro. Regulatory Mechanism in Lymphocyte Activation, ed. Lucas D. Academic Press, New York, 1977: 400.

2. Buturman WA, Vegt PA, v.d. Linden CJ, Greep JM

Cellular cytotoxicity generated in a canine mixed kidney lymphocyte cell culture. Tissue Antigens 1981; 18: 326.

3. Vegt $\mathbf{P A}$ v.d. Linden CJ, Daemen AJJM, Jeekel J, Buurman WA. Lymphocyte stimulation by canine kidney cells. Transplantation 1982; 34: 134 .

4. Main RK, Jones MJ, Birnbaurn J, Kountz SL. Mixed culture response of lymphocytes to dissociated kidney cells, Transplantation 1975; 20: 92 .

5. Mashimo S, Sakai A, Ochiai T, Kountz SL.

The mixed kidney cell-lymphocyte reaction in rats. Tissue Antigens 1976; 7: 291 .

6. Levis WR, Miller AE.

Leucocyte-skin cultures as a measure of histocompatibility in man.

Lancet 1972; is: 357 .

7. Cochrum KC, Main RK, Kountz SL.

A new matching technique: The mixed skin cell-leukocyte reaction (MSLR). Surgery 1971; 70: 97 .

8. Tanaka S, Sakai A.

Stipulation of allogeneic lymphocytes by skin epidermal cells in the rat.

Transplantation 1979; 27: 194 .

9. Steinmuller D, Wunderlich JR.

The use of freshly explanted mouse epidermal cells for the in vitro induction and detection of cellmediated cytotoxicity.

Cell Immunol 1976; 24: 146.

10. Steinmuller $D_{\text {, Tyler }} J \mathrm{D}$, David CS.

Cell mediated cytotoxicity to non-MHC alloantigens on mouse epidermal cells,

II Immunol 1981; 126: 1747.

11. Hirschberg $H$, Evensen $S A$, Hendriksen $\mathbb{T}$, Thorsby $E$.

Stimulation of human lymphocytes by allogeneic endothelial cells in vitro.

Tissue Antigens 1974; $4: 257$.

12. Vetto RM, Burger DR.

Endothelial cell stimulation of allogeneic lymphocytes.

Transplantation 1972; 14:652.

13. Vegt PA, Buturman WA, v d. Linden CJ, Daemen AJJM, Greep JM, Jeekel J.

Cell-mediated cytotoxicity towards canine kidney epithelial cells.

Transplantation 1982; 33: 465 .

14. Hirschberg H, Rolstad B, Thorsby E.

The role of human endothellal cells in allograft rejection.

Scand J Urol Nephrol Suppl 1975; 29: 33.

15. Groenewegen $\mathrm{G}$, Burman WA, w.d. Linder $\mathrm{CJ}$, Jeunhomme GMAA, Kootstra $G$.

Cellular cytotoxicity against canine endothelial cells: analysis of determinants recognised by CTL. Tissue Antigens 1983; 21: 114 . 
16. Daemen AJJM, Buurman WA, v.d. Linden CJ, Groenewegen $G$.

Canine Il 2: characterization and optimal conditions for production.

Vet Immunol Immunopath $1983 / 1984 ; 5: 247$.

17. Steinman RM, Witmer MD.

Lymphoid dendritic cells are potent stimulators of the primary mixed leukocyte reactions in mice. Proc Natl Acad Sci USA 1978; $75: 5132$.

18. Steinman RM, Kaplan G, Witmer MD, Cohn ZA.

Identification of a nowel cell type in peripheral lymphoid organs of mice. V Purification of spleen. dendritic cells, new surface markers, and maintenance in vitro.

J Exp Med 1979; 149: 1 .

19. Goodell EM, Struckle MA, Blumenstock DA, Bowers WE.

Canine dendritic cells as accessory cells in the lymphocyte activation.

Immunobiol 1982; 163: 117 (abstract).

20. Rappaport RS, Dodge GR.

Prostaglandin $\mathrm{E}$ inhibits the production of human interleukin 2.

J Exp Med 1982; 155: 943.

21. Gillis $\mathrm{S}$, Baker PE, Ruscetti FW, Smith KA.

Long term culture of human mintigen-specific cytotoxic $T$ cell lines.

J Exp Med 1978; 148: 1093.

22. Buurman WA, Daemen AJJM, Groenewegen G, Does RJJM, v.d. Linden CJ, Vegt PA.

Limiting dilution analysis of canine alloantigen reactive $\mathrm{T}$-lymphocytes.

Transplantation 1983; 35: 363 .

23. Weiss A, Brunner KT, MacDonald HR, Cerottini J山C.

Antigenic specificity of the cytolytic $T$ lymphocyte response to murine sarcoma virus-induced tumors.

III Characterization of cytolytic T lymphocyte clones specific for Moloney Leukemia virusassociated cell surface antigens.

J Exp Med 1980; 152: 1210 .

24. Lutz CT, Glasebrook AL, Fitch FW.

Allo reactive cloned $T$ cell lines III. Accessory cell requirements for the growth of cloned cytolytic

T lymphocytes.

J Immunol 1981; 126: 1404 .

25. Hirschberg $\mathrm{H}$, Bergh OJ, Thorsby $\mathrm{E}$.

Antigen presenting properties of human vascular endothelial cells.

J Exp Med 1980; 152: 2495.

26. Burger DR, Ford D, Vetto RM, et al.

Endothelial cell presentation of antigen to human $T$ cells.

Human Immunol 1981; 3: 209. 
Vascular endothelial cells present alloantigens to unprimed lymphocytes

\section{Summary}

Antigen presenting cells (APC) were removed from canine peripheral blood by carbonyl iron treatment and adherence to plastic and to nylon-wool. This treatment resulted in low proliferation in MLC and lack of generation of CMC in depleted cell suspensions compared to untreated cell suspension. The proliferative response could be restored to normal by the addition of low numbers of autologous arterial or venous endothelial cells to the MLC of depleted cell suspensions. Cytotoxicity against PHA-lymphoblasts of the stimulator was generated in the untreated MLC, as well as in the MLC of APC-depleted cell suspensions with endothelial cells added. It is concluded that arterial and venous endothelial cells can substitute for antigen presenting cells in the proliferative response of autologous lymphocytes against alloantigen and in the generation of cell-mediated cytotoxicity. Therefore, recipient endothelial cells can present shed alloantigens form an allograft to recipient lymphocytes. 
The activation of cytolytic T lymphocyte precursors ( $p-C T L$ ) is the result of cellular and humoral interaction in response to an antigen. Antigen presenting cells (APC), bearing Ia-antigens, play a crucial role in T-lymphocyte activation. Different cells have been described to function as APC in vitro, either of bone marrow origin or of other origin, such as peripheral blood monocytes, peritoneal macrophages, Kupffer cells of the liver, splenic adherent cells, alveolar macrophages, Langerhans cells of the skin, dendritic cells of lymphoid organs and endothelial cells from human umbilical vein (for review see ref. 1). Endothelial cells were reported by Hirschberg et al. and others to function as APC to primed lymphocytes for soluble antigens such as purified protein derivative of tuberculin (PPD), Herpes Simplex Virus (HSV) and mumps antigen $(2,3,4)$.

In this report we present data on the alloantigen presenting capacity of both cultured canine arterial endothelial cells and canine venous endothelial cells. Endothelial cells appeared to substitute for APC in mixed lymphocyte cultures (MLC) of APCdepleted, unprimed lymphocytes. Both proliferation and differentiation, as measured by ${ }^{3} \mathrm{H}-\mathrm{TdR}$ incorporation and cell-mediated cytotoxicity, are detected in MLC of unprimed lymphocytes with autologous arterial endothelial cells or venous endothelial cells as single source of antigen presenting cells.

\section{Materials and methods}

Dogs. All dogs used in the experiments belong to the kennels of the University of Limburg. Dogs have not been immunized in vivo with alloantigen.

Lymphocytes. Lymphocytes used in all experiments were obtained from heparinized peripheral blood by vein puncture. Blood was diluted 1:3 in Hanks Balanced Salt Solution (HBSS). One part phosphate buffered saline (PBS) containing $120 \mathrm{mg} / \mathrm{ml}$ carbonyl iron (carbonyl iron powder grade SF, Aristofarma-Interchema, Amsterdam, The Netherlands) was added to nine parts of diluted peripheral blood. The mixture was incubated with gentle shaking for 45 minutes at $38 \mathrm{C}$. Carbonyl iron was sedimented by magnetism and the supernatant was layered on top of Lymphoprep (Nyegaard, Oslo, Norway) for buoyant density centrifugation $(1000 \mathrm{~g}, 20 \mathrm{~min})$. Cells on the interface were recovered and washed twice in HBSS and resuspended in RPMI 1640 (Gibco Europe, Paisley, Scotland). The plastic non-adherent cell fraction was isolated by incubation of $3 \times 10^{7}$ cells in $10 \mathrm{ml} \mathrm{RPMI} 1640$, containing $20 \%$ fetal calf serum (FCS), in $75 \mathrm{~cm}^{2}$ tissue culture flasks (Costar, Cambridge, MA) for $1 \mathrm{hr}$ at $38 \mathrm{C}$. Nonadherent cells were decanted and washed once in RPMI. Nylonwool non-adherent cells were prepared by nylonwool treatment of the plastic nonadherent cells. $10^{7}$ cells were incubated for 45 minutes at $38 \mathrm{C}$ in a $3 \mathrm{ml}$ densely packed nylonwool column in RPMI containing $10 \%$ canine serum. Non-adherent cells were washed from the column by RPMI at $38 \mathrm{C}$. The leukocytes obtained after this treatment were non-phagocytic, non-adherent to plastic, non-adherent to nylon- 
wool and are referred to as APC-depleted lymphocytes. By morphological criteria these cells consisted of $>99 \%$ lymphocytes.

Untreated lymphocytes were obtained after buoyant density centrifugation on Lymphoprep of peripheral blood, washed twice and resuspended in RPMI.

Endothelial cells. Venous endothelial cells were cultured from the jugular or femoral vein; arterial endothelial cells were cultured from the carotid or femoral artery. Procedures have been described extensively before (5). Cells were identified as endothelial cells by their growth pattern in monolayers, their microscopical appearance and by their positive immunofluorescence with an anti-canine F VIII-related antigen antiserum. Endothelial cells were cultured in gelatin-coated plastic culture flasks in Dulbecco's Modified Minimal Essential Medium (Gibco Europe, Paisley, Scotland) containing $20 \% \mathrm{FCS}$ and antibiotics. Cells were released by incubation with Dispase grade II (Boehringer, Mannheim, FRG). Endothelial cell cultures were demonstrated to be free of dendritic cells for a number of reasons. Canine dendritic cells do not adhere to plastic (6) and therefore will be washed from the endothelial cultures. Endothelial cultures were started with endothelial cells in very low density; this allowed the observation of the growth of one cell to a homogenous population of endothelial cells. Angiotensin-converting enzyme and factor VIII related antigen, markers for endothelial cells in culture, could be demonstrated on every cell in the endothelial cell cultures with a monoclonal antibody against angiotensin-converting enzyme (7) and an anti-serum against canine factor VIII related antigen (5). Studies with the monoclonal antibody 7.2, known to react with canine MHC-class II molecules (8), did not reveal MHC-class. II positive cells in the endothelial cell cultures.

Mixed lymphocyte culture. MLC were performed by coculturing $10^{6}$ responder cells per ml with $5 \times 10^{5}, 2500$ rad X-irradiated, stimulator cells per $\mathrm{ml}$ for 6 days. Tissue culture medium was RPMI 1640 containing $100 \mathrm{IU} / \mathrm{ml}$ penicillin and 100 $\mu \mathrm{g} / \mathrm{ml}$ streptomycin and $10 \%(\mathrm{v} / \mathrm{v})$ canine serum. Cultures, performed in microtiterplates, were placed in an incubator at $38 \mathrm{C}$ with a watersaturated atmosphere of air containing $5 \% \mathrm{CO}_{2}$. Proliferation was quantitated in quadruplicate by ${ }^{3} \mathrm{H}-\mathrm{TdR}$ incorporation during the final $6 \mathrm{hr}$ of culture on day 6 of MLC. Cell-mediated cytotoxicity was measured in quadruplicate with a ${ }^{51} \mathrm{Cr}$-release assay with PHAstimulated lymphoblasts as target cells as described before (5).

\section{Results}

Depletion of $A P C$. To test the role and function of a given cell type as an alloantigen presenting cell, it is necessary to have responder and stimulator cell populations in which antigen presenting cells are absent. Treatment of peripheral blood with carbonyl iron, to deplete it of phagocytic cells, with buoyant density centrifugation, to prepare leukocytes, with plastic-adherence, to remove monocytes, and with nylonwool adherence, to deplete the lymphocyte suspensions of canine dendritic cells (6), removed the alloantigen presenting capacity. This was reflected by the absence of 
Table 1. Increase in proliferation after addition of autologous endothelial cells to APCdepleted lymphocytes in mixed lymphocyte culture.

Endothelial cells added to $10^{5}$ responder lymphocytes in MLC

\begin{tabular}{|c|c|c|c|c|c|}
\hline \multirow[t]{3}{*}{ Venous endothelial cells } & & & 0 & $10^{3}$ & $10^{4}$ \\
\hline & $A B x$ & untreated & 11,558 & 16,438 & 9,006 \\
\hline & & depleted & 270 & 2,484 & 10,111 \\
\hline \multirow[t]{4}{*}{ Exp.I } & $\mathrm{AAx}$ & untreated & 498 & 425 & $n t^{b}$ \\
\hline & & depleted & 566 & 432 & $\mathrm{nt}$ \\
\hline & $\mathrm{ABx}$ & untreated & 26,670 & 15,315 & 9,675 \\
\hline & & depleted & 924 & 7,279 & $\mathrm{nt}$ \\
\hline \multirow[t]{2}{*}{ Exp. II } & $\mathrm{AAx}$ & untreated & 518 & 409 & $\mathrm{nt}$ \\
\hline & & depleted & 247 & 300 & $\mathrm{n} t$ \\
\hline \multirow[t]{3}{*}{ Arterial endothelial cells } & & & 0 & $10^{3}$ & $10^{4}$ \\
\hline & $A B x$ & untreated & 11,558 & 10,555 & 6,030 \\
\hline & & depletted & 270 & 4,583 & 7,604 \\
\hline \multirow[t]{2}{*}{ Exp. III } & $\mathrm{A} A \mathrm{x}$ & untreated & 498 & 747 & $\mathrm{nt}$ \\
\hline & & depleted & 566 & 452 & nt \\
\hline
\end{tabular}

a Proliferation is expressed in counts per minute ${ }^{3} \mathrm{H}$-TdR incorporation and was assayed on day 6 of $M L C$.

$b$ nt: not tested.

proliferation in MLC of depleted cell suspensions, shown in the first column of Table I. It is concluded that such purified lymphocyte suspensions are devoid of the alloantigen presenting cells from peripheral blood, and thus can be used for studying putative APC.

Presentation of alloantigen by autologous vascular endothelial cells. Venous endothelial cells of the responder dog were added to MLC of APC-depleted cells. Responder endothelial cells were used to exclude reactivity against the endothelial cells (9). An increase in proliferation of lymphocytes in MLC was observed with as few as $10^{3}$ venous endothelial cells added to $10^{5}$ lymphocytes (Table I). The addition of $10^{4}$ venous endothelial cells to $10^{5}$ APC-depleted lymphocytes led to a ${ }^{3} \mathrm{H}$ $T d R$ incorporation, as a parameter for proliferation, similar to incorporation $a b-$ tained in MLC of untreated cell suspensions to which venous endothellial cells of the responder were added. Arterial endothelial cells of the responder have been added to the MLC of depleted and untreated cell populations. Also with arterial endothelial cells a marked increase in proliferation in MLC of APC-depleted lymphocytes was noted on the addition of $10^{3}$ responder arterial endothelial cells to $10^{5}$ lymphocytes. The addition of $10^{4}$ arterial endothelial cells resulted in a proliferation comparable to proliferation of untreated lymphocytes. Besides an enhancing effect on the proliferation of APC-depleted lymphocytes in MLC, the endothelial cells induced an inhibition of the proliferation of the untreated lymphocytes, especially at higher numbers of endothelial cells. 
Table 2. Generation of cell-mediated cytotocicity with autologous endothelial cells as source of antigen presenting cell. ${ }^{a}$

\begin{tabular}{|c|c|c|c|}
\hline & & \multicolumn{2}{|c|}{ Lysis $^{b}$} \\
\hline & & Untreated & Depleted \\
\hline \multirow[t]{6}{*}{$\mathrm{VEC}^{\mathrm{c}}$} & $\mathrm{ABx}$ & 30 & 7 \\
\hline & $\mathrm{ABx}+10^{3}$ VEC A & 38 & 58 \\
\hline & $\mathrm{ABx}+10^{4} \mathrm{VEC} \mathrm{A}$ & 49 & 57 \\
\hline & AAx & 5 & 1 \\
\hline & $\mathrm{AAx}+10^{3}$ VEC A & 2 & 3 \\
\hline & $\mathrm{AAx}+10^{4} \mathrm{VEC} \mathrm{A}$ & 4 & 4 \\
\hline \multirow[t]{6}{*}{$\mathrm{AEC}^{\mathrm{C}}$} & $\mathrm{ABx}$ & 13 & 4 \\
\hline & $\mathrm{ABX}+10^{3} \mathrm{AEC} \mathrm{A}$ & 12 & 39 \\
\hline & $\mathrm{ABx}+10^{4} \mathrm{AEC} \mathrm{A}$ & 6 & 60 \\
\hline & $\mathrm{AAx}$ & 2 & 1 \\
\hline & $\mathrm{AAx}+10^{3} \mathrm{AEC} \mathrm{A}$ & 0 & 0 \\
\hline & $\mathrm{AAx}+10^{4}$ AEC A & 5 & $\mathbb{1}$ \\
\hline
\end{tabular}

" Effector cells generated from $10^{5}$ responder cells in $M L C$ were tested for cell-mediated cytotocicity against $2.5 \times 10^{3}$ PHA-lymphoblasts of the stimulator dog in MLC on day 6 of $M L C$.

$b \quad$ Lysis is expressed in percentage specific lysis.

c VEC: venous endothelial cells.

AEC: arterial endothelial cells.

Generation of cell-mediated cytotoxicity with autologous endothelial cells as source of antigen presenting cells. Differentiation of lymphocytes in an immune response, beside proliferation of lymphocytes, is of utmost importance. In Table 2 data are presented on the generation in MLC of cell-mediated cytotoxicity (CMC) with endothelial cells as single source of antigen presenting cells. Two experiments from a series of experiments are shown, each experiment is representative for the specific type of endothelial cells used. MLC of untreated cells resulted in the generation of CMC with a specific lysis of stimulator PHA-lymphoblasts. Addition of responder venous endothelial cells to untreated lymphocytes did not negatively affect the generation of cytotoxicity. MLC of APC-depleted cell suspensions did not lead to generation of $\mathrm{CMC}$. Responder venous endothelial cells added to the APC-depleted MLC, resulted in high CMC. In the control MLC AAx of both untreated and APCdepleted cells $\mathrm{CMC}$ was not generated, as expected. The second part of Table II shows results obtained with arterial endothelial cells as antigen presenting cells. It appears that also arterial endothelial cells can substitute for APC in the generation of CMC.

From the data in Table $I$ it is concluded that both arterial and venous endothelial cells can substitute in vitro for antigen presenting cells in the proliferative response of lymphocytes to alloantigen. From Table 2 it is concluded that endothelial cells 
also support the differentiation of lymphocytes in the generation of cell-mediated cytotoxicity in vitro.

\section{Discussion}

The antigen presenting cells in canine peripheral blood can be removed by treatment with carbonyl iron and adherence to plastic and nylon-wool. Cell suspensions depleted in this way show very low proliferation in MLC compared to untreated cell suspensions. Proliferation in MLC of depleted cell suspensions can be restored by the addition of autologous arterial or venous endothelial cells. A similar beneficial influence of endothelial cells on the generation of CMC in MLC was observed. As the dogs used in these experiments have not been immunized in vivo with alloantigen, it is concluded from these data that both arterial endothelial cells and venous endothelial cells have the capacity to present alloantigen to autologous unprimed lymphocytes. Since the property of endothelial cells to present alioantigen is based on functional studies, conclusions regarding the mechanisms of alloantigen presentation cannot be based on these experiments. It is however obvious that a cell named APC is necessary for the proliferation and differentiation of lymphocytes in MLC, and endothelial cells appear to function as such a cell.

MHC-class II determinants, or la-like antigens, which have been strongly suggested to play a role in antigen presentation $(1,10)$ could not be detected by indirect immunofluorescence on any of the arterial endothelial cells or venous endothelial cells (Groenewegen, manuscript in preparation) with the anti-MHC-class II monoclonal antibody 7.2, known to react with canine MHC-class II molecules (8). The absence of MHC-class II antigens on the cultured cells excludes the contamination of endothelial cell cultures with dendritic cells. Pober et al. (11) however demonstrated that la-antigens can be induced on cultured endothelial cells. A basal secretion, i.e. without external stimulus, by lymphocytes of an Ia-antigen inducing factor might be the explanation for the ignition of the process of alloantigen presentation by endothelial cells. Simultaneously the induction of Ia-antigens on endothelial cells could be caused by the presentation of self"'allo"antigen by the endothelial cells to the irradiated stimulator cells, which produce an Ia-antigen inducing factor upon activation. Subsequently the responder lymphocytes can be activated by antigen presented by the endothelial cells. Nunez et al. (4) recently suggested a non-monocytic Ia positive subpopulation of cultured human umbilical vein endothelial cells to contain the antigen presenting cells. As all our endothelial cells are la-negative, as analyzed by immunofluorescence of cultured endothelial cells, our data do not agree with that suggestion.

It has been reported that in mixed cultures of allogeneic lymphocytes and endothelial cells the endothelial cells have a stimulating capacity for lymphocytes and result in proliferation of lymphocytes $(9,12,13)$. We recently demonstrated that in such mixed lymphocyte endothelial cell cultures cell-mediated cytotoxicity against endothelial cells is generated (9). In these experiments the responder cell populations were 
not depleted of antigen presenting cells. It therefore cannot be decided that endothelial cells can present their alloantigens to lymphocytes without help of respondertype alloantigen presenting cells. This is at the moment subject of study.

The demonstration of the alloantigen presenting capacity of endothelial cells, both arterial and venous, has many important implications. The role of endothelium in immune responses against microbiotic infections in tissues, might be underestimated. Furthermore the role of endothelium in vascularized allografts is likely to be of utmost importance in rejection. Endothelial cells of the recipient might present alloantigens of the donor, shed from an allograft, to lymphoyctes of the recipient. The implications of the alloantigen presenting capacity of endothelial cells deserve to be studied extensively. As endothelial cells can be grown in vitro, many identical, even clonally derived, cells can be obtained for experiments on antigen-presentation. A new tool for the study of the role of the la-antigens in antigen presentation is of fered, as endotheliall cells are Ia-negative during culture and still appear to function as alloantigen presenting cells.

Sofar reports on antigen presentation by endothelial cells describe the presentation of soluble antigens to primed lymphocytes $(2,3,4)$. We demonstrated that endothelial cells in low numbers can substitute in vitro for APC to allow the proliferative response of autologous unprimed lymphocytes against alloantigeri and the generation of cell-mediated cytotoxicity. Next we will analyse the function of vascular endothelial cells in the presentation of self'"allo"'antigen to unprimed allogeneic lymphocytes in mixed lymphocyte endothelial cell cultures, and the influence of lymphokines on the alloantigen presentation to unprimed lymphocytes by vascular endothelial cells in vitro.

\section{Acknowledgements}

The authors thank Mrs. G.M.A.A. Jeunhomme and Mrs. A.J.J.M. Daemen for technical assistance and Mrs. K. Spronck for secretarial assistance. This study was supported by grant No. C 81.297 from the Nierstichting Nederland (Dutch Kidney Foundation).

Dr. H.J. Deeg (Fred Hutchinson Cancer Research Center, Seattle, WA) supplied us with the monoclonal antibody 7.2 and Dr. R. Auerbach (University of Wisconsin, Madison, WI) provided the monoclonal antibody reactive with angiotensinconverting enzyme ( $\alpha$-ACE 3.1.1).

\section{Literature cited}

1. Lipsiky PE, Kettman JR. Accessory cells unrelated to mononuclear phagocytes and not of bone marrow origin. Immunol Today $1982 ; 3: 36$.

2. Burger DR, Ford D, Vetto RM, Hamblin A, Goldstein A, Hubbard M, Dumonde DC. Endothelial cell presentation of antigen to human $T$ cells.

Human Immunol 1981; 3: 209. 
3. Hirschberg $H_{\text {, Bergh }}$ of, Thorwby $\mathbf{E}$.

Antigen-presenting properties of human vascular endothelial cells.

J Exp Med 1980; 152: 249 s.

4. Nunez $G$, Ball EJ, Stastny P.

Accessory cell function of human endotheliall cells. I. A subpopulation of la positive cells is required. for antigen presentation.

J Irmunol 1983; 131:666.

5. Groenewegen $G$, Buurman WA, van der Lnden CJ, Jeunhomme GMAA, Kootstra G.

Cellular cytotoxicity against canime endothelial cells. Analysis of determinants recognized by CTL.

Tissue Antigens $1983 ; 21: 114$.

6. Goodell EM, Struckle MA, Blumenstock DA, Bowers WE.

Canine dendritic cells as accessory cells in the canine lymphocyte activation.

Immunobiol. 1982; 163: 117 (abstract).

7. Auerbach $\mathbb{R}$, Alby L, Grieves J, Joseph $J$, Lindgren $C$. Morrisey LW, Sidky YA, Tu M, Watt. SL. Monoclonal antibody against angiotensin-converting enzyme: Its use as a marker for murine, bovine and human endothelial cells.

Proc Natl Acad Sci, USA, 1982; 79: 7891.

8. Deeg HJ, Wulff JC, DeRose $\mathrm{S}$, Sale GE, Braun M, Brown MA, Springmeyer SC, Martin PJ, Storb R.

Unusual distribution of Ia-like antigens on canine lymphocytes.

Immunogenetics 1982;16:445.

9. Groenewegen $\mathrm{G}$, Butrman WA, Jeunhomme GMAA, van der Linden CJ, Vegt PA, Kootstra G. In vitro stimulation of lymphocytes by wascular endothelial cells. A study with canine arterial and venous endothelial cells.

Transplantation 1984; 37: 206.

10. Weinberger $O$, Germain RN, Springer T, Burakoff SJ.

Rolle of syngeneic lat accessory cells in the generation of allospecific CTL responses.

J Immunol 1982; 129: 694.

11. Pober IS, Gimbrone MA, Cotran RS, Reiss CS, Burakoff SJ, Fiers W Ault KA.

Ia expression by vascular endothelium is inducible by activated $T$ cells and by human interferon. J Exp Med 1983; 157: 1339.

12. Hirschberg $H_{*}$ Evensen SA, Hendriksen $T$, Thorsby $E$.

Stimulation of human lymphocytes by allogenic endothelial cells in vitro.

Tissue Antigens 1.974; 4: 257.

13. Vetto RM, Burger DR.

Endothelial cell stimulation of allogenetic lymphocytes.

Transplantation $1972 ; 14: 652$. 


\section{CHAPTER 8}

Self-alloantigen presentation by canine endothelial cells in vitro.

\section{Summary}

Self-alloantigen presented by certain donor cells in an allograft to recipient lymphocytes can result in allograft rejection. The precise type of donor cell in a graft responsible for this aspects of allograft rejection remains to be established. Here is reported on the capacity of canine venous endothelial cells to activate, in vitro, allogeneic lymphocytes to proliferation and differentiation, by self-alloantigen presentation.

Antigen presenting cell (APC) depleted lymphocyte populations, prepared in a multistep procedure and tested for absence of APC, were cocultured with allogeneic venous endothelial cells. Proliferation and differentiation into cytotoxic $T$ lymphocytes were measured. While mixed lymphocyte culture of APC-depleted lymphocytes did not result in proliferation and differentiation, coculture of allogeneic APC-depleted lymphocytes with venous endothelial cells resulted in proliferation and generation of cell-mediated cytotoxicity in these cultures. It is concluded that canine venous endothelial cells in vitro have the capacity of self-alloantigen presentation. The data suggest an essential role for endothelium in the initial phase of allograft rejection. 
The presentation of antigens by specialized cells is an initial event in the immune response (1). Two types of antigen presentation can be distinguished. The first type, that occurs in immune responses against e.g. viruses, is the presentation of antigens by accessory cells, which take up and express on the cell membrane the antigens involved, to activate lymphocytes: accessory cell type. The second type of antigen presentation occurs in the immunological artificial situation of allografting. In the graft certain donor cells present their alloantigen, self-alloantigen presentation, to lymphocytes of the recipient, which are then triggered to proliferation and differentiation. The first type of antigen presenting cells (accessory cell type) are macrophages (1), dendritic cells (2), B lymphocytes (3), epidermal Langerhans cells (4) and endothelial cells (5-8). For self-alloantigen presentation monocytes (9), dendritic cells $(10,11,12)$ and epidermal Langerhans cells $(13,14)$ have been suggested. These cells have the capacity to activate allogeneic T lymphocytes, independently from accessory cells of the responder.

Endothelial cells are known to activate lymphocytes in vitro $(15,16,17)$, but the dependence of this phenomenon on accessory cells is unknown. We have tested the capacity of endothelial cells to activate lymphocytes without need for additional accessory cells.

\section{Materials and methods}

Animals. Dogs have been used in the experiments. Dogs were kept in the kennels of the University of Limburg. The dogs used in this study have not been immunized in vivo with alloantigen.

Endothelial cells. Canine venous endothelial cells (VEC) were cultured as described previously (18). Cultures reacted homogeneously for the endothelial cell markers angiotensin converting enzyme and canine FVIII related antigen. Contamination of the endothelial cell cultures with non-endothelial cells was excluded (17).

Preparation of lymphocyte suspensions. Lymphocytes were isolated from heparinized blood. Untreated lymphocytes were prepared by density centrifugation of blood on Lymphoprep (Nyegaard, Oslo, Norway). Lymphocytes depleted of antigen presenting cells were prepared in a multistep procedure (8). In brief, diluted blood was incubated $45 \mathrm{~min}$ at $38^{\circ} \mathrm{C}$ with $12 \mathrm{mg} / \mathrm{ml}$ carbonyl iron to remove phagocytic cells. Leukocytes were separated by density centrifugation. After washing of the cells, plastic adherent cells were removed during $1 \mathrm{~h}$ at $38^{\circ} \mathrm{C}$ incubation of the cells on plastic in RPMI 1640 containing $20 \%$ foetal calf serum. The plastic nonadherent cells were decanted, washed once and resuspended in RPMI 1640 containing $10 \%$ canine serum. The cells were then incubated $45 \mathrm{~min}$ at $38^{\circ} \mathrm{C}$ in nylon-wool columns to remove canine dendritic cells (19). The cells obtained in this multistep procedure are nonphagocytic, nonadherent to plastic and nonadherent to nylon-wool. These cells consisted of $>99 \%$ lymphocytes by morphological criteria and are referred to as APC-depleted lymphocytes (8). 
Mixed cultures. APC-depleted lymphocytes or untreated lymphocytes were suspended in RPMI 1640, supplemented with 10\% heat-inactivated canine serum and antibiotics (100 IU penicillin and $100 \mu \mathrm{g} / \mathrm{ml}$ streptomycin) at $10^{6} \mathrm{cell} / \mathrm{ml}$. The lymphocytes were cocultured with similarly prepared stimulator lymphocytes (4000 rad $\mathrm{X}$-irradiated) at a responder-stimulator ratio of $2: 1$ or were cocultured with endothelial cells at responder-stimulator ratio of 10:1. Mixed cultures were performed in culture flasks, placed in a water-saturated atmosphere of air containing $5 \%$ $\mathrm{CO}_{2}$, at $38^{\circ} \mathrm{C}$.

Proliferation and differentiation assays. Proliferation of lymphocytes in mixed cultures was determined by measurement of ${ }^{3} \mathrm{H}$-TdR-incorporation. On day 8 of culture, $0.1 \mathrm{ml}$ of the resuspended culture was pipeted into microtiter wells to which $0.5 \mu \mathrm{Ci}{ }^{3} \mathrm{H}-\mathrm{TdR}$ was added (17) during the final $4 \mathrm{~h}$ of incubation. Proliferation in each culture flask was assayed in quadruplicate. Proliferation is expressed in counts per minute (cpm). Differentiation was determined by measurement of cell-mediated cytotoxicity in a ${ }^{51} \mathrm{Cr}$-release assay, as described earlier (18). For detection of nonspecific lysis third party or responder type lymphoblasts were used. Cell-mediated cytotoxicity was assayed in quadruplicate. Specific lysis of a target cell was calculated as usual (17). In syngeneic combinations of responder and stimulator cells, neither proliferation nor cell-mediated cytotoxicity could be detected (results not shown).

\section{Results}

The capacity of endothelial cells to stimulate allogeneic lymphocytes in mixed lymphocyte endothelial cell cultures (MLEC) without the presence of antigen presenting cells (APC) in the lymphocyte population was studied. Contamination of the endothelial cells with non-endothelial cells was excluded on basis of homogeneous reactivity with two markers used for identification of endothelium in vitro.

Table 1 shows the proliferative response of untreated and APC-depleted lymphocytes in mixed cultures. Four representative experiments from a series of experi-

Table 1 Proliferation in mixed cultures of untreated and APC depleted lymphocytes.

\begin{tabular}{llrrrr} 
& & \multicolumn{4}{c}{ Experiment } \\
\cline { 3 - 5 } & & \multicolumn{1}{c}{ I } & II & III & IV \\
\hline Untreated & MLC A/B $^{x}$ & $3,022^{\mathrm{a}}$ & 10,166 & $\mathbf{n t}^{\mathrm{b}}$ & 15,404 \\
Lymphocytes & MLEC A/VEC B $^{\mathrm{b}}$ & 2,134 & 12,713 & 8,180 & 4,990 \\
APC-depleted & MLC A/B $^{x}$ & 705 & 562 & 776 & 1,101 \\
Lymphocytes & MLEC A/VEC B $^{\mathrm{x}}$ & 2,831 & 25,251 & 12,109 & 19,295 \\
\hline
\end{tabular}

a Proliferation is expressed in counts per minute ${ }^{3} H-T d R$ in corporation.

b nt: not tested. 
Table 2. Cell-mediated cytaroxicity generated in mixed cultures of lymphocytes.

\begin{tabular}{ccc}
\multicolumn{3}{c}{ Target cell } \\
\hline $\begin{array}{c}\text { Stimulator } \\
\text { VEC }\end{array}$ & $\begin{array}{c}\text { Stimulator } \\
\text { lymphoblast }\end{array}$ & $\begin{array}{c}\text { Non-specific } \\
\text { lymphoblast }\end{array}$
\end{tabular}

\section{Experiment I}

(responder 3284; stimulator 126)

$\begin{array}{llrrr}\text { Untreated } & \text { MLC } & 25^{\mathrm{a}} & 14 & -23 \\ \text { Lymphocytes } & \text { MLEC } & 83 & 74 & -4 \\ & & & -2 & -7 \\ \text { APC-depleted } & \text { MLC } & -5 & 87 & -14 \\ \text { Lymphocytes } & \text { MLEC } & 82 & & \end{array}$

Experiment II

(responder 774; stimulator 132)

$\begin{array}{llrrr}\text { Untreated } & \text { MLC } & 27 & 22 & -13 \\ \text { Lymphocytes } & \text { MLEC } & 29 & 40 & -17 \\ & & & 1 & \\ \text { APC-depleted } & \text { MLC } & 0 & 32 & -6\end{array}$

Experiment III

(responder 787; stimulator 126)

Untreated MLEC

21

2

$-1$

Lymphocytes

APC-depleted

MLEC

66

63

1

Lymphocytes

Experiment $\mathrm{IV}$

(responder 823; stimulator 3284)

Untreated

MLEC

28

15

nt

Lymphocytes

APC-depleted

MLEC

32

68

nt

Lymphocytes

a Percentage specific lysis is given. Effector target ratio used was 20:1.

$b \quad$ Non-specific lymphoblasts of responder or third party origin were included for control of specificity of lysis.

- nt: not tested.

ments are shown. Mixed lymphocyte culture (MLC) of untreated lymphocytes results in proliferation of lymphocytes whereas proliferation in MLC of APCdepleted lymphocytes is negligible. It can therefore be concluded that APC are indeed removed from the lymphocyte population by the employed depletion procedure. Proliferation in MLEC is not affected by the depletion of antigen presenting cells from the lymphocyte population since in MLEC of both untreated lymphocytes 
and APC-depleted lymphocytes significant ${ }^{3} \mathrm{H}$-TdR incorporation is observed. Incorporation of ${ }^{3} \mathrm{H}-\mathrm{TdR}$ in MLEC with APC-depleted lymphocytes was 4 to 40 times higher than incorporation in MLC of APC-depleted lymphocytes. The experiments indicate that venous endothelial cells are capable of induction of a proliferative response in cultures of APC-depleted lymphocytes and therefore have the capacity of self-alloantigen presentation.

Differentiation of lymphocytes in mixed cultures was studied by measurement of cell-mediated cytotoxicity (CMC). The results of four experiments from a series of eight are given in Table 2. Three different target cells have been used: lymphoblasts and endothelial cells of the stimulator and lympho blasts of a third party or the responder. These targets cells have been included for analysis of specificity of lysis. The effector cells from MLC of untreated lymphocytes lysed both lymphoblasts and endothelial cells of the stimulator, without lysis of nonspecific lymphoblasts. An identical pattern of lysis was found for effector cells from MLEC of untreated lymphocytes. The cells from MLC with APC-depleted lymphocytes are not cytotoxic, even not at effector-target ratios higher than 20:1 (data not given). In MLEC with APC-depleted lymphocytes high specific cytotoxicity was obtained. The cells of these cultures which were shown to proliferate, appeared also to differentiate into cytotoxic $T$ lymphocytes. It can be con cluded that endothelial cells are capable of stimulating lym phocytes to proliferation and differentiation in the absence of APC in the lymphocyte population and therefore function as self-alloantigen presenting cells.

\section{Discussion}

The precise cell in an allograft that induces rejection of the allograft by the immune system of the recipient remains to be determined. The 'passenger leukocyte' of donor origin, later identified as 'dendritic cell', has been suggested to be responsible for the induction of rejection. However, it has been reported that, in the canine model, skin allografts of a bone-marrow chimera were rejected by the marrow donor (20). Similar findings were observed for kidney allografts (Storb, personal communication). Skin graft rejection provoked by non-bone-marrow derived cells in murine skin was recently described (21). These findings cast doubt on the exclusive role of bone-marrow-derived cells in induction of allograft rejection. The cell type responsible for induction of allograft rejection must however be in reach of the host's immune system and must express MHC-class II antigens, which have an essential role in the rejection process.

Fabre (22) questioned the clinical relevance of the rat kidney allograft model since only bone-marrow-derived dendritic cells express MHC-class II antigens in the rat kidney; this in contrast to the human situation in which also capillary endothelial cells express MHC-class II antigens (23).

Recently we described the capacity of both canine arterial and venous endothelial cells to function as antigen presenting cell for alloantigens to syngeneic lymphocytes 
in mixed lymphocyte cultures (8). The expression of MHC-class II antigens by endothelial cells, an essential property of antigen presenting cells, could be induced by lymphokines in vitro $(24,25)$. Here, we studied the capacity of canine venous endothelial cells to stimulate allogeneic lymphocytes, without the need for additional antigen presenting cells. For this purpose a system, in which APC were removed from the lymphocyte population in a multi-step procedure, was used (8). It appeared that APC-depleted lymphocytes could be stimulated to proliferation and differentiation into cytotoxic $T$ cells, by venous endothelial cells. Since the endothelial cells are capable of lymphocyte stimulation in the absence of APC in the lymphocyte population we conclude that venous endothelial cells function as self-alloantigen presenting cell. Preliminary experiments demonstrate that also arterial endothelial cells have this capacity (unpublished observations).

The reported humoral reactions during rejection against non-MHC antigens on endothelium $(26,27)$ can be explained by the self-alloantigen presenting capacity of endothelial cells. These antigens may be presented to lymphocytes by the endothelial cells in association with the immunogenic MHC-class II antigens, resulting in a reaction against these non-MHC antigens. The detrimental ef fect on allograft survival of such antigens has been demonstrated (28). Since in the human (23) and canine kidney MHC-class II antigens are present, on glomerular and peritubular capillary endothelium which is an essential property of antigen presenting cells, it can be assumed, on basis of the data presented, that these cells can present their selfalloantigens. The essential presence of MHC-class II antigens on the endothelial cells in the cultures are most likely induced by the lymphokines produced by the responder T lymphocyte population, since we could show that supernatants of unstimulated lymphocytes can induce MHC-class II antigens on endothelial cells (25). It is therefore concluded that endothelial cells are responsible for induction of rejection of vascularized allografts.

\section{Acknowledgements}

The authors thank Mrs. G.M.A.A. Jeunhomme, Mrs. A.J.J.M. Daemen and Mrs. E.E.M. Spronken for their technical assis tance, and Mrs. K. Spronck for her excellent secretarial assistance.

\section{Literature}

1. Unanue ER, Beller DJ, Lu CY, Allen PM.

Antigen presentation: comments on its regulation and mechanism.

I Immunol 1984; 132: 1.

2. Sunshine GH, Katz DR, Feldmann M.

Dendritic cells induce $\mathrm{T}$ cell proliferation to synthetic antigens under $\mathbf{I r}$-gene control.

J Exp Med 1980; 152: 1817.

3. Chesmut RW, Grey HM.

Studies on the capacity of $B$ cells to serve as antigen presenting cells. 
J Immaunol 1981; 126:1075.

4. Braathen $C R$, Thorsby $E$.

Studies on human epidermal Langerhans cells. I. Alloactiviting and antigen-presenting capacity.

Scand J Immunol 1980; 11: 401 .

5. Hirschberg H, Bergli OJ, Thorsby $\mathrm{E}$.

Antigen-presenting properties of human vascular endothelial cells.

J Exp Med 1980;152: 249 S.

6. Burger DR, Ford: D, Vetto RM, Hamblin A, Goldstein A, Hubbard M, Dumonde DC.

Endothelial cell presentation of antigen to haman $T$ cells.

Human Immunol 1981; 3: 209.

7. Nunez G, Bqll EJ, Stastny P.

Accessory cell function of human endothelial cells. I. A subpopulation of la positive cells is required for antigen presentation.

J Immunol 19:83; 131: 666 .

8. Groenewegen $G$, Buurman WA.

Vascular endothelial cells present alloantigens to unprimed lymphocytes.

Scand J Immunol 1984; 19: 269.

9. Gonwa TA, Picker LJ, Rafe HV, Gavert SM, Silver J, Stobo JD.

Antigen presenting capabilities of human monocytes correlates with their expression of HLA-DS, an la-determinant distinct from HLA-DR.

IImmunol 1983; 130; 706.

10. Steinman RM, Witmer MD.

Lymphoid dendritic cells are potent stimulators of the primary mixed leukocyte reaction in mice.

Proc Natl Acad Sci USA 1978; 75: 5132.

11. Klinkert WEF, LaBadie JH, Bowers WE.

Accessory and stimulating properties of dendritic cells and macrophages isolated from various rat tissues.

I Exp Med 1982; 156:1.

12. Van Voorhis WC, Valinsky J, Hoffman E, Luban J, Hair LS, Steinman RM.

Relative efficacy of human monocytes and dendritic cells as accessory cells for $T$ cell replication.

J Exp Med 1983; 158: 174.

13. Pollack MS, Goldenhersh M, Chin-Louie J, Safai B.

The functional study of DR-positive human epidermal Langerhans cells in mixed cell cultures with allogeneic lymphocytes.

Clin Immunol and Immunopath 1982;24:15.

14. Tsuchida $T$, lijima $M$, Fugw wara $H$, Pehamberger $H$, Shearer GM, Katz $S J$.

Epidermal Langerhans cells can function as stimulatory cells but not as accessory cells in CTL induction.

J Immunol 1984; 132: 1163.

15. Vetto RM, Burger DR.

Endothelial cell stimulation of allogerneic lymphocytes.

Transplantation 1972; 14:652.

16. Hirschberg $\mathrm{H}$, Evensen SA, Hendriksen T, Thorsby $\mathrm{E}$.

Stimulation of buman lymphocytes by allogeneic endothelial cells in witro.

Tissue Antigens 1974; 4:257.

17. Groenewegen G, Buuman WA, Jeunhomme GMAA, van der Linden CJ, Vegt PA, Kootstra $G$. In vitro stimulation of Jymphocytes by wascular endothelial cells. A study with canine arterial and venous endothelial cells.

Transplantation 1984; 37: 206.

18. Groenewegen $G$, Buurman WA, van der Linden CJ, Jeunhomme GMAA, Kootstra $G$. Cellular cytotoxicity against canine endothelial cells. Analysis of determinants tecognized by CTL. Tissue Antigens 1983; 21: 114.

19. Goodell EM, Struckle MA, Blumenstock DA, Bowers WE.

Canine dendritic cells as accessory cells in the canine lymphocyte activation.

Immunobiology 1982; 163: 117 (abstract).

20. Schroeder M-L, Storb R, Graham TC, Weiden PL.

Canine radiation chimeras: an attempt to demonstrate serum blocking factors by an in vivo approach. 
J Imminal 1975; 14:540.

21. Stuart PM, Bech-Maier B, Melvold RW.

Provocation of skin graft rejection across murine class II differences by non-bone-martow-derived cells.

Transplantation 1984; $37: 393$.

22. Fabre JW.

Rat kidney allograft model: was it all too good to be true?

Transplantation $1982 ; 34: 223$.

23. Natali PG, de Martino C, Marcellini M, Quaranta V, Ferrone S.

Expression of la-like antigens on the vasculature of human kidney.

Clinical Immunol and Immunopath $1981 ; 20: 11$.

24. Pober JS, Gimbrone MA, Cotran RS, Reis CS, Burakoff SI, Fiers W, Ault KA.

la expression by vascular endothelium is inducible by activated $\mathrm{T}$ cells and by human gamma-interferon.

J Exp Med 1983; 157: 1339.

25. Groenewegen $G$, Buurman WA, Jeunhomme GMAA, van der Linden $C J$.

Cyclosporin $\mathrm{A}$ affects MHC-class II antigen expression by arterial and venous endothelial in witro. Transplantation, in press.

26. Moreas JR, Stastny $P$.

A new antigen system expressed in human endothelial cells.

J Clin Invest 1977; 60: 449.

27. Paul LC, van Es LA, van Rood JJ, van Leeuwen A, Brutel de la Rivière G, de Graeff J.

Antibodies directed against antigens on the endothelium of peritubular capillaries in patients with rejecting renal allografts.

Transplantation 1979; $27: 175$.

28. Cerilli J, Brasile L, Clarke J, Galouzis J.

The vascular endothelial cell (VEC) specific antigen system: three years experience in monocyte crossmatching.

Transplant Proc 1985; 17: 567. 
Cyclosporin A affects MHC-class II antigen expression by arterial and venous endothelium in vitro.

\section{Summary}

MHC-class II antigens play a crucial role in immunological responses. The expression of MHC-class II antigens for monocytes and endothelial cells was reported to be variable and could be induced by gamma-interferon. Here is reported on the MHC-class II antigen expression in vitro by arterial and venous endothelial cells, as detected with FACS-analysis and indirect immunofluorescence with a monoclonal antibody against canine MHC-class II antigens. It appeared that cultured endothelial cells did not express MHC-class II antigens. The expression could be induced during a three day incubation period in lymphokine containing supernatant produced in mixed leukocyte culture (MLC).

Cyclosporin A (CyA) added to allogeneic stimulated or unstimulated lymphocytes in MLC inhibited the induction of expression by the supernatant of MLC. The addition of CyA to a MLC supernatant did not have an inhibitory effect.

It is concludied that CyA inhibits the production of an MHC-class II antigen inducing lymphokine, produced by lymphocytes in mixed cultures; allogeneic stimulation is not necessary for production of the lymphokine.

It is postulated that the mode of action of CyA in prolongation of allograft survival is based on inhibited MHC-class II antigen expression by endothelial cells. 
Monocytes, dendritic cells and certain vascular endothelial cells are cells with a membrane expression of MHC-class II antigens. Interaction of T helper lymphocytes and MHC-class II antigens result in activation of T helper cells ${ }_{y}$ leading to amplification of the immune response. It appeared that the MHC-class II antigens expression on monocytes is inconstant as shown in vivo (1) and in vitro $(2,3,4)$. The expression could be induced by products of activated lymphocytes, i.e. lymphokines. The lymphokine was shown to have gamma interferon (IFN- $\gamma$ ) activity (5) and it was recently demonstrated that IFN- $\gamma$ induced the expression of MHC-class II antigens on macrophages (6). The MHC-class II antigen expression on endothelium in vascularized allografts is likely to play an important role in allograft rejection. MHC-class II antigen expression by endothelial cells increased in murine skin grafts during rejection (7), and the expression was induced in vitro by IFN- $\gamma$ on human umbilical vein endothelial cells (HUVE) (8).

Prevention and treatment of rejection of allografts by modification of MHC-class II antigen expression will be feasible as soon as knowledge of the regulation of expression of these antigens and procedures interfering with MHC-class II antigen expression are available. For monocytes lymphokine induced MHC-class II antigen expression could be modulated by prostaglandins (9) and is inhibited by endotoxin (10) and corticosteroids (11).

Here we studied the expression of MHC-class II antigens on cultured canine endothelial cells from adult dogs and the effects of lymphokines on this expression. We also studied the effect of cyclosporin $\mathrm{A}$ (CyA) on the antigen expression since CyA is an inhibitor of the synthesis of lymphokines and a drug known to prolong allograft survival.

Materials and Methods

Endothelial cells. Arterial endothelial cells (AEC) were obtained by collagenase treatment from the femoral artery of dogs; venous endothelial cells (VEC) were obtained from the femoral vein. Culture procedures for the endothelial cells were described before (12). Cells were identified as endothelial cells by their homogenous positive reactivity with an anti dog F VIII related antigen antiserum and with a monoclonal antibody against angiotensin converting enzyme (13), Near clonal origin of the endothelial cells permitted the exclusion of contamination of the endothelial cell cultures with other cells (14).

To prevent auto-fluorescence of the endothelial cells due to phenol red taken up from the tissue culture medium and retained in the Golgi-system of the cells, the endothelial cells were cultured in medium without phenol red.

Lymphokine production. Lymphokine containing supernatant was produced in unidirectional mixed leukocyte cultures (MLC) of peripheral blood leukocytes of dogs mismatched for one or two DLA haplotypes, performed as usual (12). Cell-free su- 

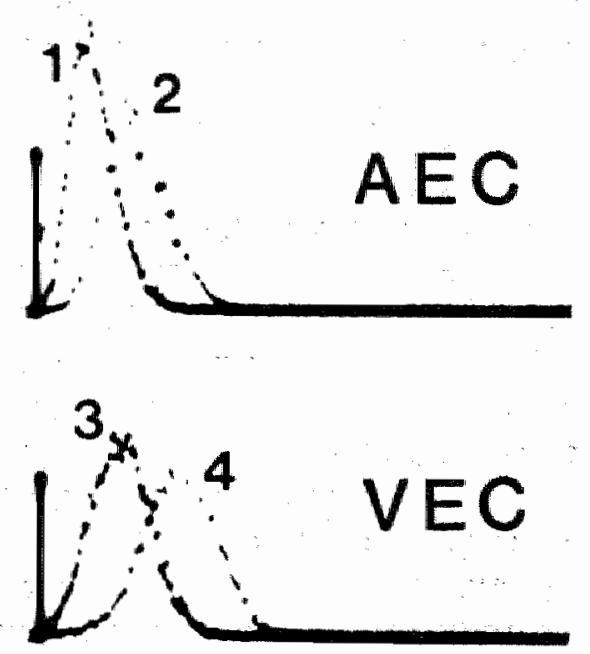

Figure.1

MHC-class II antigen expression by endothelial cells in culture and after incubation in lymphokine."

a. Fiuorescence intensity was analyzed on a FACS IV; intensity in a log scate (horizontal axis) was plorred against cell number (vertical axis).

$I$ and 3: fluorescence of cultured $A E C$, respectively $V E C$.

2 and 4: fluorescence of $A E C$, resp VEC incubated $72 \mathrm{hr}$ in lymphokine.

Fluorescence of control monoclonal antibody was similar to curves $l$ and 3. Percentages positive cells were in curves, 1 to 4 respectively $2,4,26$ and $57 \%$ in the experiment shown.

pernatant of $M L C$ was harvested by centrifugation and filtering (pore size $0.22 \mu \mathrm{m}$ ). Supernatants were stored at $-20^{\circ} \mathrm{C}$ untill use. Proliferation of cells in MLC was quantitated by ${ }^{3} \mathrm{H}-\mathrm{TdR}$ incorporation. CyA was dissolved in DMSO, $10 \mathrm{mg} / \mathrm{ml}$, and diluted to $5 \mu \mathrm{g} / \mathrm{ml}$ in RPMI 1640 for use in MLC. Controls contained an equal concentration of the solvent DMSO. CyA was a gift of Dr. Borel, Sandoz Ltd, Basel, Switzerland.

For sake of simplicity only, lymphokine containing supernatant is called lymphokine.

Incubation of endothelial cells in lymphokine. Endothelial cells were subcultured at least six times before use. The endothelial cells were released from the culture flasks with a short incubation in Dispase grade II (Boehringer, Mannheim, FRG). Cells were seeded in a subconfluent density and cultured for one day. Culture medium was washed off and replaced with lymphokine. RPMI 1640 with $10 \%$ canine serum, the complete MLC medium, served as the control for the effect of lymphokine. Cells were harvested with $0.03 \%$ EDTA in phosphate buffered saline and the unfixed cells were examined for membrane expression of MHC-class II antigens.

Immunofluorescence. MHC-class II antigens were detected with indirect immunofluorescence. Monoclonal antibody 7.5.10.1 (15), known to react with canine MHCclass II products as established by immunoprecipitation and gel electrophoresis (16) was used as first layer. The monoclonal antibody 7.5.10.1 was a gift of Dr. Koning, 
Table 1. Effect of dilution of lymphokine on induction of expression of MHC-class II anitgens by cultured venous endothelial cells.

\begin{tabular}{lcccc}
\hline & & \multicolumn{3}{c}{ Dilution $^{\mathrm{a}}$} \\
\cline { 3 - 5 } $\begin{array}{l}\text { Lymphokine } \\
\text { source }\end{array}$ & Undiluted & $1: 4$ & $1: 16$ & $1: 64$ \\
\hline MLC A/B & $68^{\mathrm{b}}$ & 36 & 17 & 6 \\
MLC A/A & 12 & 5 & 2 & 2 \\
control & 0 & - & - & - \\
\hline
\end{tabular}

\footnotetext{
a Lymphokine was dituted with control medium.

b percentage positive cells by FACS-analysis.
}

Leiden, The Netherlands. Nonspecific binding of murine monoclonal antibodies was recognized with a monoclonal antibody against a human colonic carcinoma associated antigen (Parlam, a gift of Dr. Verstijnen, Maastricht, The Netherlands). Second layer was fluorescein labeled rabbit immunoglobulin specific for mouse immunoglobulins (Nordic, Tilburg, the Netherlands). The immunofluorescence staining procedure for membrane antigens was performed on ice, as usual. For analysis of fluorescence intensities a FACS IV (Becton Dickinson, Sunnyvale, CA) was used.

\section{Results}

Expression of MHC-class II antigens by cultured endothelial cells. Expression of membrane bound MHC-class II antigens could not be detected with the anti MHCclass II antibody on cultured AEC and VEC, that had been subcultured at least six times. These cells expressed the endothelial cell markers F VIII related antigen and angiotensin converting enzyme which characterized the cells as endothelial cells (data not shown).

The effect of lymphokine on the expression of MHC-class II antigen was studied. It appeared that a substantial fraction of endothelial cells in culture expressed MHC-class II antigens on their cell-surfaces after a three day incubation period with lymphokine, produced in MLC. The induction of MHC-class II antigen expression was observed on both AEC and VEC. The mean percentage of VEC positive for MHC-class II antigens after a three day incubation in lymphokine in a series of eight experiments was $75 \%$ (range $47-91 \%$ ). For AEC a mean percentage of $39 \%$ (range $28-44 \%$ ) was observed. The results of two representative experiments are shown in Figure 1.

Not only lymphokine produced by allogeneic stimulated lymphocytes in MLC $\mathrm{A} / \mathrm{B}^{\mathrm{x}}$, induced $\mathrm{MHC}$-class II antigens, but also supernatants of control cultures of lymphocytes in MLC $\mathrm{A} / \mathrm{A}^{x}$ appeared to contain the inducing factor. In dilution experiments it was observed that supernatant of allogeneic stimulated lymphocyte contained a 4 to 16 times higher titer of the inductor of MHC-class II antigen expression, compared to supernatants of control lymphocyte cultures (Table 1). 
Table 2. Effect of CyA on lymphokine induced MHC-class II antigen expression on endowehial cells in vitro.

\begin{tabular}{cccc} 
& Experiment I & Experiment II & Experiment III \\
\cline { 2 - 4 } Presence of & percentage & Percentage & Percen- \\
CyA & positive cells & positive cells & tage \\
& & posi- \\
& & tive \\
& & cells
\end{tabular}

$\begin{array}{lllllllll}\text { during after } & \text { cpm }^{\natural} & \text { AEC } & \text { VEC } & \text { cpm } & \text { AEC } & \text { VEC } & \text { cpm } & \text { VEC }\end{array}$

\begin{tabular}{|c|c|c|c|c|c|c|c|c|c|c|}
\hline Control & - & - & - & 3 & 3 & - & 2 & 2 & - & 4 \\
\hline \multirow{3}{*}{$\mathrm{MLC} A / \mathbb{B}^{\mathrm{k}}$} & - &. & 13,209 & 28 & 85 & 25,000 & 20 & 27 & 9,000 & 41 \\
\hline & + & - & 710 & 7 & 4 & 175 & 7 & 2 & 300 & 0 \\
\hline & - & + & 13,209 & 44 & 91 & 25,000 & $n t^{d}$ & 47 & 9,000 & 75 \\
\hline \multirow{3}{*}{$M L C A / A^{x}$} & - & - & 600 & 23 & 69 & 800 & 14 & 10 & 1,500 & 16 \\
\hline & + & - & 148 & 7 & 6 & 350 & 2 & $\mathbb{1}$ & 175 & 3 \\
\hline & - & + & 600 & 19 & 58 & 800 & 7 & 2 & 1,500 & 17 \\
\hline
\end{tabular}

a. CyA $(5 \mu \mathrm{g} / \mathrm{ml})$ was not added or was present during $M L C$ for lymphokine production ${ }^{\text {or }}$ was only present during incubation of the endothelial cells in lymphokine.

b. ${ }^{3} H$-TdR uptake of the MLC for lymphokine production is expressed in counts per minute.

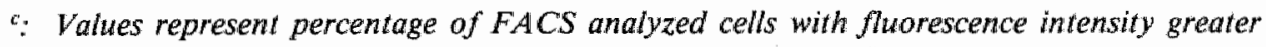
than background fluorescence (control monoclonal antibody).

at: not tested.

Time responsiveness of lymphokine induced $M H C$-class II expression. The expression of MHC-class II antigens on VEC after different incubation times in lymphokine was studied with a FACS IV. The results of a representative experiment with VEC from a series of five experiments are shown in Figure 2. Not earlier than $16 \mathrm{hr}$ after start of the incubation of VEC in lymphokine the appearance of MHC-class II antigens could be detected. Longer incubation in lymphokine resulted in an increase of both the percentage of positive cells and the mean fluorescence intensity of the cells.

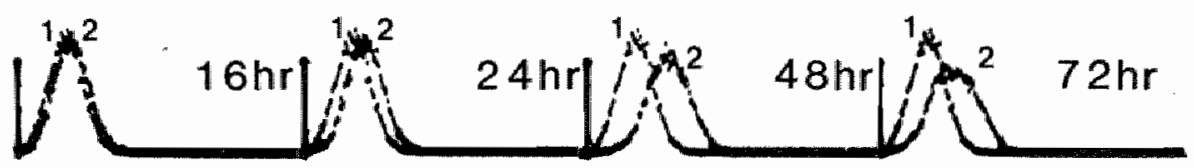

Fijgure: 2 .

Imorease in expression of MHC-class II antigens on VEC during incubation in lymphokine."

a. Fluorescence infensity (horizontal axis) was plotted against cell number (vertical axis).

Incubarion times of $0,16,24,48$ and 72 hr are indicated.

1: Avorescence intensify at $t=0 \mathrm{hr}$.

2. Auorescence intensity at time indicated. 
The maximum fluorescence intensity was reached at $72 \mathrm{hr}$. For AEC similar results as VEC were observed (dlata not shown).

CyA affects lymphokine induced MHC-class II antigen expression. CyA is a known inhibitor of the production of lymphokines. Since lymphokines were shown to induce MHC-class II antigens on cell-membranes of endothelial cells in vitro, we studied the effect of Cy A on lymphokine induced MHC-class II antigens expression.

Allogeneic stimulated lymphocytes from MLC A/B ${ }^{x}$ showed proliferation, indicated by a high ${ }^{3} \mathrm{H}$-TdR incorporation. The supernatant of the allogeneic stimulated lymhocytes induced an increased MHC-class II antigen expression on both AEC and VEC. The addition of CyA, $5 \mu \mathrm{g} / \mathrm{ml}$, to the MLC at onset of the culture resulted in a markedly reduced ${ }^{3} \mathrm{H}-\mathrm{TdR}$ incorporation, as reported by others $(17,18)$. Moreover, the addition of CyA to a MLC produced a supernatant that lacked capacity to induce MHC-class II antigen expression on endothelial cells.

Table 2 shows the data from a typical experiment from a series of six experiments. The inhibitory effect of CyA on induced MHC-class II antigen expression was studied in two phases: inhibition of the process of induction of MHC-class II antigen expression or inhibition of production of lymphokine in MLC.

The possible inhibitory effect of CyA on the induction of expression was studied by addition of CyA to a supernatant capable to induce expression of MHC-class II antigen. CyA did not have an inhibitory effect in such an experiment and therefore it can be excluded that the observed effect of CyA is due to inactivation of the lymphokine or inhibition of the process of induction of MHC-class II antigens. Incubation of endothelial cells in a supernatant of lymphocytes from control MLC $\mathrm{A} / \mathrm{A}^{\mathrm{x}}$, did induce the expression of MHC-class II antigens on endothelial cells, whereas the induction could be blocked by addition of CyA to the MLC A/A . This indicated that the point of application of the inhibitory effect of CyA on MHCclass II antigen expression is at the level of the lymphocyte.

\section{Discussion}

MHC-class II expression by endothelial cells in the murine skin in vivo was shown to be variable (7): endothelial cells of normal skin did not express MHC-class II antigens, whereas during rejection of skin allografts these antigens could be detected on the vasculature of the grafts. Furthermore the induction in vitro of the MHC-class II antigen expression on cultured human umbilical vein endothelial cells (HUVE) was reported. The MHC-class II antigen expression could be induced by lymphokines and by IFN- $\gamma$ (8). Stimulation of lymphocytes (14) and presentation of alloantigen by endothelial cells (19) already suggested MHC-class II antigen expression by endothelial cells. In this communication it is reported that arterial and venous endothelial cells, that were taken from blood vessels of adult animals, expressed MHCclass II antigens in response to exposure to lymphokine.

MHC-class II expression on endothelial cells in vivo in dogs is similar to the human situation. In both species MHC-class II antigens could be detected in sections of the 
kidney on venous endothelial cells, whereas the endothelium of arteries did not express MHC-class II antigens (20, manuscript in preparation). On cultured endothelial cells from arteries and veins from adult, healthy dogs, MHC-class II antigens could not be detected. However, these antigens could be induced in a three day incubation period in lymphokine containing medium, as was reported for macrophages (1-6) and HUVE (8). For VEC the findings are similar to the findings with HUVE (8). MHC-class II expression was found in vivo, loss of expression was observed during culture of the cells, and the expression could be induced by lymphokine. AEC lacked expression in vivo and during culture. However the expression could also be induced in vitro by lymphokine.

Keratinocytes and gut epidermal cells, that normally do not express MHC-class II antigens, were reported to express detectable amounts of MHC-class II antigens in situations as graft versus host disease and local infections (21). Expression of MHCclass II antigens was also observed on normally MHC-class II antigen negative colonic epithelial cells in areas surrounding colonic tumors, especially when infiltrates of lymphocytes in and around such tumors were present (22). These data strongly suggest that also AEC would be able to express MHC-class II antigens in vivo in conditions of high concentrations of MHC-class II inducing factors. Functionally the MHC-class II antigen expression is important since it leads to localization and amplification of ongoing immune responses via MHC-class II restricted $\mathrm{T}$ helper lymphocytes.

MHC-class II antigens play an important role in the process of rejection of allograft. CyA is known in vivo to prevent rejection of allograft and in vitro to inhibit the production of lymphokines such as Interleukin 1 and Interleukin $2(17,18)$. Since lymphokines induce $\mathrm{MHC}$-class II antigen expression, it was of importance to study the effect of CyA on lymphokines and MHC-class II antigen induction. A reduction of expression of MHC-class II antigens by endothelial cells would present an important mode of action of CyA in prolongation of allograft survival.

Supernatant of allogeneic stimulated lymphocytes in MLC $A / B^{x}$ to which CyA was added from the start of the culture did not induce MHC-class II expression on endothelial cells. The inhibitory effect of CyA could not be attributed to inactivation of the responsible lymphokines or to inhibition of the expression per se, since addition of CyA to a MLC-supernatant capable of induction of MHC-class II expression, did not prevent expression. The effect of $\mathrm{CyA}$ is also not due to inhibited proliferation of allogeneic stimulated lymphocytes in MLC, since supernatant of MLC A/A $\mathbf{A}^{x}$, that lacked proliferation, was capable of MHC-class II antigen induction. The induction could not be inhibited by addition of $\mathrm{CyA}$ to the supernatant at end of MLC, and was inhibited when CyA was present during MLC A/Ax. From the experiments it was concluded that CyA inhibits the production of a lymphokine that induces MHC-class II expression. This conclusion is strongly supported by the recent findings of Reem et al. (23), who reported that CyA inhibits the synthesis of IFN- $\gamma$ by human thymocytes and T lymphocytes, while a role for IFN- $\gamma$ in induction of MHC-class II antigens on monocytes $(5,6)$ and HUVE (8) was demonstrated. 
A new postulation on the mode of action of CyA in prolongation of allograft survival is made. MHC-class II antigen expression, because of its function in the center of immune responses via antigen presentation, is advantageous in immunological reactions against noxious agents. MHC-class II antigen expression, induced and sustained by lymphocyte secreted mediators, is disadvantageous in allografting, since the immune response against the graft will be started and amplified. CyA reduces MHC-class II antigen expression by inhibition of lymphokine production, and therefore prevents a situation in which the rejection process can start.

The postulated mode of action of CyA sheds new light on the data of de Waal et al. (7). These authors reported that CyA prevented rejection of skin allografts in mouse and that abcense of a rejection process resulted in absence of MHC-class II antigen on the endothelium of the graft. MHC-class II antigens could be detected on the endothelium of the skin graft during untreated rejection. De Waal et al. (7) suggested that CyA prevents rejection of murine skin allografts and therefore of the rejection dependent endothelial MHC-class II antigen expression. We suggest that CyA inhibits endothelial MHC-class II antigen expression and because of that prevents rejection.

\section{Acknowledgements}

The authors thank Mrs. E.E.M. Spronken for FACS operating, Mrs. A.J.J.M. Daemen for technical assistance and Mrs. K. Spronck for secretarial assistance.

\section{Literature cited}

1. Scher MG, Beller DJ, Unanue ER.

Demonstration of a soluble mediator that induces exudates rich in Ia-positive macrophages.

J Exp Med 1980; 152: 1684.

2. Steinman RM, Nogueira N, Witmer MD, Tydings JD, Millman JS.

Lymphokine enhances the expression and synthesis of la antigens on cultured mouse peritoneal macrophages.

J Exp Med 1980; 152: 1248 .

3. Steeg PS, Moor RN, Oppenheim JJ.

Regulation of murime macrophage la-antigen expression by products of activated spleen cells.

J Exp Med 1980; 152: 1734 .

4. Calamai EG, Beller DJ, Unanue ER.

Regulation of macrophage populations. IV Modulation of Ia-expression in bone marrow-derived niacrophages.

J Immunol 1982; 128: 1692.

5. Steeg PS, Moor RN, Johnson HM, Oppenheim JJ.

Regulation of murine macrophage Ia antigen expression by a lymphokine with immune interferon activity.

J Exp Med 1982; 156" 1780.

6. Wong GCHW, Clark-Lewis J, McKimm-Breschkin JL, Harris AW, Schroder JW.

Interferon induces enhancet expression of Ia and $\mathrm{H}-2$ antigens on $\mathrm{B}$ lymphoid, macrophage and myeloid cell lines.

J Immunol 1983; 131: 788 . 
7. de Waal RMW, Bogman MJJ, Maas CN, Cornelissen LMH, Tax WJM, Koene RAP.

Variable expression of la antigens on the vascular endothelium of mouse skin allografits.

Nature 1983; 303: 426.

8. Pober JS, Gïmbrone MA, Cotran RS, Reis CS, Burakoff SJ, Fiers W, Ault KA.

Ia expression by vascular endothelium is inducible by activated $T$ cells and by human gamma-interferon.

J Exp Med 1983; 157: 1339 .

9. Snyder DS, Beller DJ, Unamue ER.

Prostaglandins modulate macrophage la expression.

Nature 1981; 299: 163.

10. Steeg PS, Johnson HM, Oppenheim JJ.

Regulation of murine macrophage Ia antigen expression by an immune interferon-like lymphokine: inhibitory effect of endotoxin.

J Immunol 1982; 129: 2402.

11. Snyder DS, Unanue ER.

Corticosteroids inhibit murine macrophage la expression and Interleukin production.

J Irmmunol 1982; 129: 1803.

12. Groenewegen G, Buurman WA, van der Linden CJ, Jeunhomme GMAA, Kootstra $G$.

Cellular cytotoxicity against canine endothelial cells. Analysis of determinants recognized by CTL. Tissue Antigens 1983; 21: 114 .

13. Auerbach $R_{\text {, Alby }} \mathrm{L}$, Grieves $\mathrm{J}$ et al.

Monoclonal antibody against angiotensin-converting enzyme: its use as a marker for murine bovine and human endothelial cells.

Proc Natl Acad Sci USA 1982; 79: 7891.

14. Groenewegen G, Buurman WA, Jeunhomme GMAA, wan der Linden CJ, Vegt PA, Kootstra $G$. In vitro stimulation of lymphocytes by vascular endothelial cells. A study with canine arterial and venous endothelial cells.

Transplantation 1984; 37: 206.

15. Koning $F$, Schreuder $J$, Giphart $M$, Bruning $H$. A mouse monoclonal antibody detecting a $D R$ related MTZ-like specifici ty. Serology and biochemistry.

Human Immunol 1984; 9: 221 .

16. Groenewegen G, Buurman WA.

Vascular endothelial cells present alloantigens to unprimed lymphocytes.

Scand J Immunol 1984; 19: 269.

17. Bunjes D, Hardt C, Röllinghoff $M$, Wagner $H$.

Cyclosporin A mediates immunosuppression of primary cytotoxic $\mathrm{T}$ cell responses by impairing the release of interleukin 1 and interleukin 2 .

Eur J Immunol 1981; 11: 657.

18. Andrus L, Lafferty $\mathrm{KJ}$.

Inhibition of T-cell activity by cyclosporin A.

Scand J Immunol 1982; 15: 449.

19. Doveren RFC, Schutte B, Buurman WA, Groenewegen $G$, vd Linden CJ.

Class II antigens on canine $T$ lymphocytes.

Tissue Antigens, in press.

20. Natali $P G$, De Martino $C$, Marcellini $M$, Quaranta $V$, Ferrone S.

Expression of la-like antigens on the vasculature of human kidney.

Clin Immunol Immunopathol 1981; 20: 11 .

21. Barclay $A N$, Mason DW.

Induction of la antigens in rat epidermal cells and gut epithelium by immunological stimuli.

J Exp Med 1982; 156: 1665.

22. Rogmum TO, Brandtzaeg $P$, Thorud E.

Is heterogeneous expression of HLA-DR antigens and CEA along with DNA-profile variations evidence of phenotypic instability and clonal proliferation in human large bowel carcinomas?

Br ICancer 1983; 48: 543.

23. Reem GH, Cook LA, wilcek I.

Gamma interferon synthesis by human thymocytes and $\mathrm{T}$ lymphocytes is inhibited by cyclosporin $\mathrm{A}$.

Science 1983: 221: 63 . 



\section{CHAPTER 10}

In vivo expression of MHC-Class II antigens by endothelium is lymphokine dependent

Summary

Increased expression of MHC-class II antigens, an essential phenomenon in the regulation of immunological processes, is caused in vitro by soluble mediators (1-4). The mechanism which underlies MHC-class II antigen expression in vivo on certain cells, e.g. endothelial cells in the absence of immune stimulation has not been studied. Here it is demonstrated that expression of MHC-class II antigens is not a constitutive property of endothelial cells, since otherwise MHC-class II antigen positive endothelial cells do not express these antigens during treatment with cyclosporin A. In vivo $\mathrm{MHC}$-class II antigen expression by canine endothelial cells is therefore dependent on factors, most likely the lymphokine interferon-gamma produced by the immune system, whose secretion is inhibited by cyclosporin $\mathrm{A}$. 
The concept of the essential role of MHC-class II antigens in the regulation of immunological processes is accepted. Variations in expression are important in these regulatory functions. In vitro a variable $\mathrm{MHC}$-class II antigen expression on cell surfaces has been repeatedly established. MHC-class II antigen expression could be induced by lymphokines on monocytes (1-3). The lymphokine responsible for the augmented MHC-class II antigen expression on monocytes in vitro has been demonstrated to be gamma interferon (IFN- $\gamma$ ) (4). Recently, an intermediate messenger, produced by monocytes in response to IFN- $\gamma$, has been reported to be inwolved in this process (5). The MHC-class II antigen inducing capacity of IFN- $\gamma$ in vitro was also clearly shown for endothelial cells, derived from human umbilical vein (6), and for fibroblasts (7).

Sofar it is unknown whether the in vivo MHC-class II antigen expression of capillary endothelial cells, as observed in man (8-11) and dog, is a constitutive property of these cells. A number of observations suggests the involvement in vivo of lymphokines in the regulation of MHC-class II antigen expression. Immunological stimuli caused a variability in the expression in different experimental models (12-16). Murine kidney epithelial cells became Ia positive during acute graft versus host disease (12). Rat skin $(13,14)$ and gut epithelium $(14)$, both MHC-class II antigen negative cells, expressed MHC-class II antigens during graft versus host disease and local infections (15). Grafted murine skin contained endothelial cells, which expressed laantigens only during rejection of the graft (16). The in vitro data (1-7) strongly support the suggestion that also in vivo lymphokines are involved in the enhanced expression during immunological stimuli. We studied whether the normal 'physiological' expression of MHC-class II antigens is dependent on such factors. This assumed dependency can be analysed with the use of the drug cyclosporin A (CyA). CyA was shown to inhibit in vitro the production of the factor accountable for MHC-class II antigen expression (17-19).

An in vivo model was selected in which by analysis of the effect of CyA the assumed dependency of the normal endothelial MHC-class II antigen expression on lymphokines could be studied. The canine model was chosen since in the dog MHC-class Il antigens can be detected in the skin on capillary endothelial cells and in the kidney on glomerular and peritubular capillary endothelium similarly as in man (8-11). The dependency of MHC-class II antigen expression on lymphokines was studied in skin and kidney biopsies of five dogs that were treated with CyA. The drug was given once daily as oral drinking solution, prepared by Sandoz, Switzerland. Drug blood through levels were monitored on HPLC and maintained between 0.2 and 0.4 $\mathrm{mg} / \mathrm{l}$. The administered CyA dosages ranged from $15.0 \mathrm{mg} / \mathrm{kg}$ to $22.5 \mathrm{mg} / \mathrm{kg}$ per day. Drug treatment did not affect the health of the treated dogs. Serum creatinine concentrations and urea concentrations as parameters for renal function were unaffected. Creatinine concentrations ranged from 40 to $60 \mu \mathrm{Mol} / 1$ during treatment (normal range in dogs $30-120 \mu \mathrm{Mol} / 1$ ). Wound healing of incision for biopsies was unimpaired. 
Figure 1. Distriburion of MHC-class It antigens in the kidney before (A) and during (B) treatment with CyA (magnification: $x$ 400).

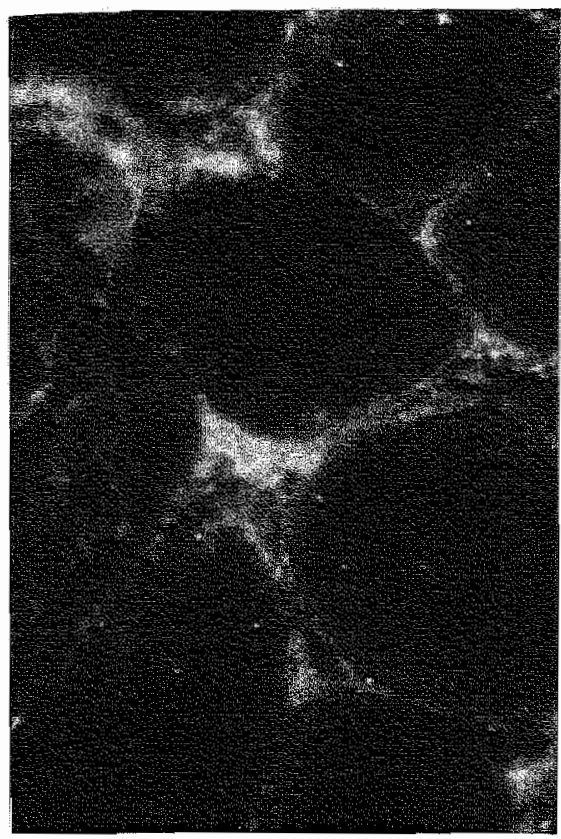

A $B$

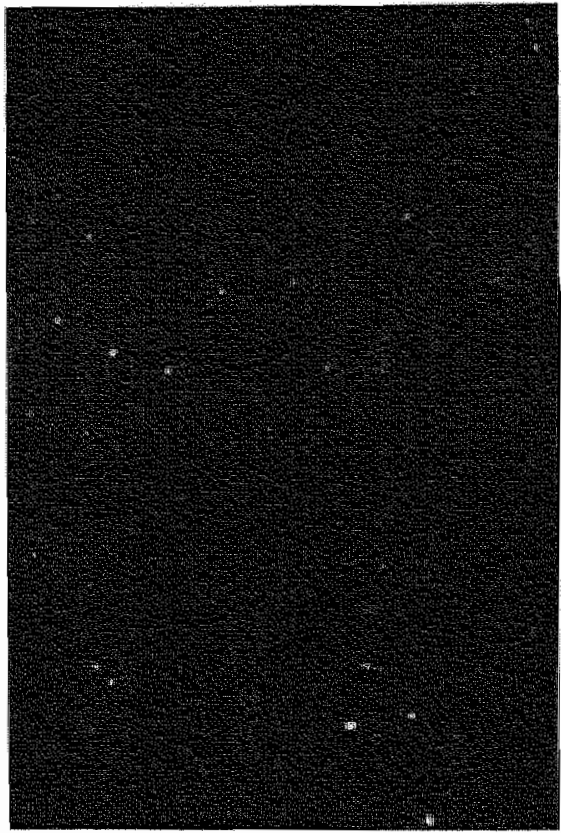

Figure 2. Distribution of $F$ VIII related antigen in the kidney before (A) and during (B) treatment with CyAl (magnification: $x 400$ ).
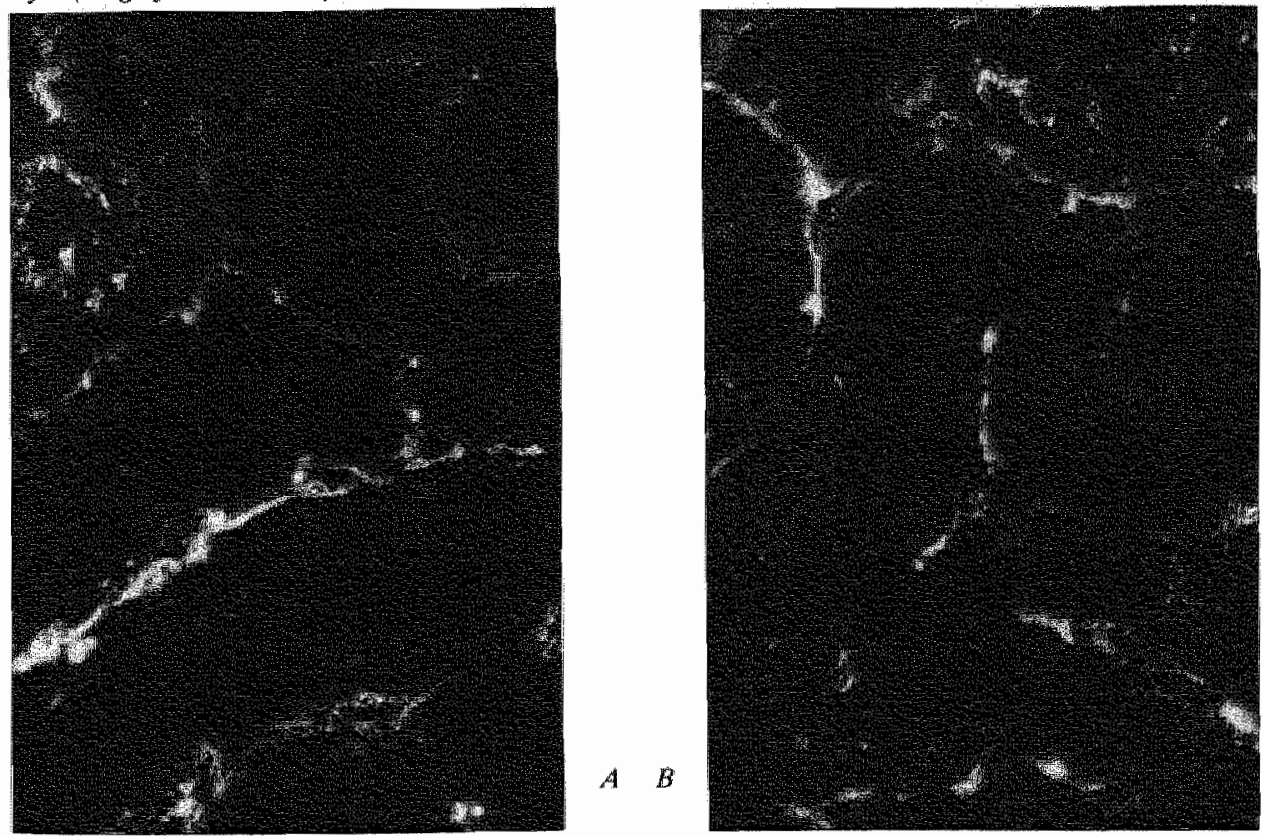

Antiserwm specific for dog FVIII related antigen was used for identification of endothelitum in tissue sections. Im biopsies $A$ and $B$, taken respectively before treatment and after 10 days of administration of $C y A$, endothelial cells of glomerular and peritubular capillaries are stained. 
Legend to Figure 1 .

Monoclonal antibodies $7.2(24)$ and 7.5.10.1 (25), known to crossreact with canine MHCclass II artigens (26), were used in the ascites form in this study. Both monoclonal antibodies gave dentical patterns of immunofluorescence. Reactivity of antibody 7.5.10.1 is shown. MHC-class II antigens on peritubular and glomerular capillary endothelial cells are stained before treatment with $C y, A$, shown in biopsy $A$. Biopsy $B$, taken after 10 days of administration of $C y A$ is devold of antigens reacting with anti-MHC-class II reagents, even at amibody concentration 10 fold higher than the concentration which appeared on titration to be optimal in blopsies of untreated dogs.

Healthy dogs, beagles, from the colony of the University of Maastricht were used for the experiments. Dogs were regularly screened for infections; latest vaccination had been given at least 12 months prior to use in experiment. Tissue specimens, obtained by open biopsies, were snap-frozen in isopentane, cooled on dry ice. Tissue sections, $4 \mu \mathrm{m}$, were fixated in aceton at $-20^{\circ} \mathrm{C}$ and rehydrated in phosphate buffered saline (PBS) at room temperature. Subsequenty, sections were incubated $30 \mathrm{~min}$ at room temperature with the desired antibody, washed for $15 \mathrm{~min}$ in PBS and incubated with an appropriate fluoresceine labeled second antibady. Antibodies were used at wice the concentration that was in titration still saturating, to achieve maximal sensitivity of the fluorescence technique. After a final wash the section was embedded in glycerol.

Dogs were treated with cyclosporin A. Plasma through levels were kept between 0.2 and 0.4 mg/l as measured on HPLC. CyA was administered as oral drinking solution containing 100 $m g / m l$ CyA.

The expression of MHC-class II antigens in tissue biopsies during treatment with CyA was studied with indirect immunofluorescence with monoclonal anti MHCclass II reagents as shown in figure 1. Renal biopsies of the first dog studied, were taken on day 10, 19 and 32 of treatment. Figure 1A show the presence of MHC-class II antigens before treatment, which cannot be detected in figure $1 \mathrm{~B}$, during treatment. All biopsies taken after 10 days of treatment gave an identical result of absence of MHC-class II antigens on the renal vasculature. Identification of endothelial cells by distribution of the marker F VIII related antigen (20) is illustrated in figure 2. Before and during treatment with $\mathrm{CyA}$ the distribution of this antigen in endothelium was not changed. However, MHC-class II antigen distribution is different before and during treatment. The findings were confirmed in a second dog treated with $\mathrm{Cy} A$ and biopsied at day 10,20 and 33 of treatment. In three other dogs, MHC-class II antigens could not be detected in renal biopsies taken on day 20 of treatment, whereas the distribution of F VIII related antigen was not changed.

A second vascular bed was studied in the skin of CyA-treated dogs. The skin also allowed the study of expression of MHC-class II antigens on Langerhans cells of the skin before and during treatment with CyA. The results of skin biopsies, together with kidney biopsies, have been summarized in Table 1. Expression of F VIII related antigen was similar before and during treatment. Endothelial expression of MHC-class II antigens was absent during treatment in biopsies taken on day 12 of treatment, whereas before treatment the antigens could easily be detected on the endothelial cells. Continuation of therapy till day 25 showed a continued absence of the antigens on endothelial cells, whereas the distribution of F VIII related antigen was not affected. It is not likely that the disappearance of MHC-class II antigens 
Table 1 Expression of MHC-class II antigens in skin and kidney biopsies of dogs, before and during treatment with cyclosporin A.

Kidney

glomerular peritubular

endothelium endothelium
Skin
Langerhars cells

\begin{tabular}{lllll}
\hline $\begin{array}{l}\text { before treatment } \\
\text { during treatment }\end{array}$ & + & + & + & + \\
\hline
\end{tabular}

MHC-class II antigen expression was studied with monoclonal antibodies in an indirect immunoffuroscence technique. Presence or absence of antigens is indicated by respectively + art -.

from the vasculature of both skin and kidney was caused by a toxic effect of CyA for endothelium, since in both tissues the distribution and expression of the marker for endothelium, F VIII related antigen, was similar before and during treatment with CyA.

In contrast to the disappearance of the endothelial MHC-class II antigens, the expression of MHC-class II antigens by Langerhans cells of the skin was not affected by treatment of dogs with CyA (Table 1). Whereas treatment for ten days resulted in loss of antigens from endothelium, treatment as long as 25 days did not cause a change in MHC-class II antigen expression on Langerhans cells of the skin.

In vitro $\mathrm{MHC}$-class II antigen expression on endothelial cells is induced and maintained by lymphokines. CyA does not influence lymphokine-induced MHC-class II antigen expression on endothelial cells in vitro, but has an effect via inhibition of the production of lymphokines responsible for the antigen expression (17-19). In analogy, the expression of MHC-class II antigens on endothelium in vivo is expected to be lymphokine-dependent, since treatment with CyA, which inhibits the production of the relevant factors, results in the observed decreased expression of MHC-class II antigens on endothelium in skin and kidney. An effect of the immune systern on the expression was already likely from the increased expression of MHC-class II antigens during immunological stimuli (12-16). It can now be concluded from this study that the immune system sustains the normal expression of MHC-class II antigens on endothelium via lymphokines.

The nature of the lymphokines involved in vivo remains to be established. It is most likely that this lymphokine is IFN- $\gamma$, since it is known to induce the expression in vitro of MHC-class II antigens $(4,6,7)$ and its production is inhibited by CyA (19). Our data strongly suggest that a basal secretion of IFN- $\gamma(21)$ is the cause of the 'normal' MHC-class II antigen expression on endothelial cells. The expression of MHC-class II antigens in vivo on capillary and venous endothelium and not on arterial endothelium suggests a difference in sensitivity of these cells, since arterial endothelium can be induced in vitro by lymphokines to express the antigens $(17,18)$. During immunological stimuli high concentrations of IFN- $\gamma$ can induce MHC-class II 
antigens on cells with low sensitivity for this lymphokine. Differences in reactivity to lymphokines might be part of the regulation of expression of MHC-class II antigens on different cell types and therefore of immunological responsiveness.

The experiments demonstrate that regulation of MHC-class II antigen expression on endothelial cells and on Langerhans cells of the skin is different. The expression on endothelium was abrogated by CyA, whereas the expression on Langerhans cells was not affected by CyA. Factors recently reported (5) might be involved in the regulation of MHC-class II antigens on Langerhans cells of the skin.

This is, to our knowledge, the first demonstration that the expression of MHC-class II antigens in vivo on endothelial cells is not a constitutive property of these cells. The expression in vivo on capillary endothelium in the canine kidney and skin is sustained by the immune system via lymphokines. The presence of MHC-class II antigens on the capillary endothelial cells might be a consequence of the rheological characteristics of the vessels lined by these cells. The conditions for interactions between lymphocytes and endothelial cells, known for their capacity to present antigens $(22,23)$, is most favourable on these MHC-class II positive capillary endothelial cells.

The variations in MHC-class II antigen expression of endothelial cells, due to dependence of expression on products of the immune system, leading to new insights in the control of immune responses, offers interesting opportunities for evaluation of the immune status in patients, both in hyper- and hypo-immune situations. Moreover, the abrogation of endothelial MHC-class II antigen expression caused by CyA offers a new explanation for its immunosuppressive effect.

\section{Acknowledgements}

The authors acknowledge the technical assistance of Mrs. G.M.A.A. Jeunhomme, Mrs. A.J.J.M. Daemen and Mrs. E.E.M. Spronken and Mrs. K. Spronck for secretarial assistance.

CyA was a gift of Mr. Stokvis, Sandoz Ltd., Uden, The Netherlands. CyA concentrations were determined by the Pharmacological and Toxicological Laboratory, Hospital St. Annadal, Maastricht, The Netherlands.

This work was supported by grant No. C81.297 from Nier Stichting Nederland and grant No. 29.57.10 from Fungo.

\section{Literature cited}

1. Steinman RM, Nogueitra N, Witmer MD, Tydings JD, Mellman JS.

Lymphokine enhances the expression and synthesis of Ia antigens on cultured mouse peritoneal macrophages.

I Exp Med 1980; 152: 1248.

2. Scher $M$, Beller DJ, Unanue $\mathbb{E R}$.

Demonstration of a soluble mediator that induces exudates rich in la-pasitive macrophages.

J Exp Med 1980; 152: 1684. 
3. Steeg PS, Moore RN, Oppenheim JJ.

Regulation of murine macrophage la-antigen expression by products of activated spleen cells.

J Exp Med 1980; 152: 1734.

4. Steeg PS, Moore RN, Johnson HM, Oppenheim JJ.

Regulation of murine macrophage Ia-antigen expression by a lymphokine with inmune interferon activity.

J Exp Med 1982; 156: 1780 .

5. Walker EB, Maino V, Sanchez-Lanier M, Warner N, Stewart C.

Murine gamma interferon activates the release of a macrophage-deriwed la-inducing factor that transfers la inductive capacity.

J Exp Med 1984; 159: 1532.

6. Pober JS, Gimbrone MA, Cotran RS, Reiss CS, Burakoff SJ, Fiers WA, Ault KA.

Ia-expression by vascular endothelium is inducible by activated $T$ cells and by human gamma interferon.

J Exp Med 1983; 157: 1339.

7. Pober JS, Collins T, Gimbrone MA, Cotran RS, Gitlin JD, Fiers W, Clayberger C, Krensky AM, Burakoff SJ, Reiss CS.

Lymphocyte recognize human vascular endothelial and dermal fibroblasts la-antigens induced by recombinant immune interferon.

Nature 1983; 305: 726.

8. Natali $\mathbb{P G}_{n}$ De Martino C, Marcellini $M$, Quaranta V, Ferrone S.

Expression of Ia-like antigens on the vasculature of human kidney.

Clin Immunol Immunopathol 1981; 20: 11 .

9. Paul LC, van Es LA, Baldwin III WA.

Antigens in human renal allografts.

Clin Immunol Immunopathol 1981; 19: 206.

10. Scott H, Brandtzaeg P, Hirschberg H, Solheim BG, Thorsby E.

Vascular and renal distribution of HLA-DR-like antigens.

Tissue Antigens 1981; 18: 195.

11. Fuggle SV, Errasti P, Daar AS, Fabre JW, Ting A, Morris PJ.

Localisation of MHC (HLA ABC and DR) antigens in 46 kidneys: differences in HLA-DR staining of tubules between kidneys.

Transplantation 1983; 35: 385 .

12. Wadgymar A, Urmson J, Baumal R, Halloran PF.

Changes in la expression in mouse kidney durimg graft-ws-host disease.

J Immunol 1984; 132: 1826.

13. Lampert JA, Suitters AJ, Chisholm PM.

Expression of la antigens on epidermal keratinocytes in graft-vs-host disease.

Nature 1981; 293: 149.

14. Mason DW, Dallman M, Barclay AN.

Graft-versus-host disease induces expression of la antigens in rat epidermal cells and gut epithelium.

Nature 1981; 293: 150.

15. Barclay AN, Mason DW.

Induction of la antigens in rat epidermal cells and gut epithelium by immunological stimuli.

J Exp Med 1982; 156: 1665.

16. de Waal RMW, Bogman MJJ, Maass CN, Cornelissen LMH, Tax WJM, Koene RAP.

Variable expression of la antigensi on the vascular endothelium of mouse skin allografts.

Nature 1983; 303: 426.

17. Groenewegen G, Buurman WA, Jeunhomme GMAA.

Class II expression by endothelial cells is affected by cyclosporine.

Transplant Proc 1985; 17: 1417.

18. Groenewegen G, Buurman WA, Jeunhomme GMAA, van der Linden $\mathrm{CJ}$.

Cyclosporin A affects MHC-class II antigen expression by arterial and venous endothelium in vitro.

Transplantation, in press.

19. Reem $\mathrm{GH}_{3}$ Cook LA, vilcek $J$.

Gamma interferon synthesis by human thymocytes and $T$ lymphocytes is inhibited by cyclosporin $A$.

Science $1983 ; 221: 63$. 
20. Hoyer LW, de las Santos RP. Hoyes JR.

Antilhemophilic factor antigens: localization in endothelial cells by immunofuorescence microscopy.

J Clin Invest 1973; $52: 2737$.

21. Stewart II WE.

In 'The Interferon System' pp. $55-57$ and 75-76, Springer Verlag, Wien, 1973.

22. Hirschberg $\mathrm{H}$, Bergh $\mathrm{OJ}$, Thorsby $\mathbb{E}$.

Antigen presenting properties of human vascular endothelial cells.

J Exp Med 1980; 152:249S.

23. Groenewegen $\mathrm{G}_{*}$ Bururman WA.

Vascular endothelial cells present alloantigens to unprimed lymphocytes.

Scand I Immunol 1984; 19: 269.

24. Deeg HJ, Wulff IC, DeRose $\mathrm{S}$, Sale GE, Braun M, Brown MA, Springmeyer SC, Martin PJ, Storb R.

Unusual distribution of la-like antigens on canine lymphocytes.

Immunogenetics 1982;16:445.

25. Koning $\mathrm{F}_{\text {, Schreuder }} \mathrm{J}$, Giphart $\mathrm{M}$, Bruning $\mathrm{H}$.

A mouse monoclonal antibody detecting a DR-related MT2-like specificity. Serology and biochemistry.

Human Immunol 1984; 9; 221 .

26. Doveren RFC, Bururman WA, Schutte B, Groenewegen G, v.d. Linden CJ.

Class II antigens on canine $T$ lymphocytes.

Tissue Antigens, in press. 


\section{General discussion of the experiments}

In a vascularized allograft, the first cell of the donor organ that is encountered by elements of the host's immune system, present in the circulating blood, is the vascular endothelial cell of donor origin. Study of the role and function of endothelial cells in immunological reactions can therefore clarify the events leading to rejection of allografts.

An initial event in the rejection process is the activation of lymphocytes by stimulating cells of the donor, cells with the capacity of self-alloantigen presentation of donor antigens. Originally it was assumed that passenger leukocytes of the donor, later identified as dendritic cells, are the stimulating cells in an allograft. This concept was undermined by the demonstration that non-lymphoid cells are capable of lymphocyte stimulation (1-10). In these experiments with non-lymphoid stimulator cells the responder lymphocyte population was not depleted of antigen-presenting cells, precluding the possibility to know the capacity of non-lymphoid cells to present their self-alloantigens. In chapter 8 it is demonstrated that endothelial cells have this capacity of self-alloantigen presentation in vitro. Therefore endothelial cells could function in a vascularized allograft as a donor cell responsible for lymphocyte activation.

Endothelial cells are target of activated lymphocytes: both delayed type hypersensitivity reactions, via lymphokines, and cell-mediated cytotoxicity, via cytolysis, can be directed against endothelium. Lymphokines, the mediators of delayed type hypersensitivity reactions, have been shown in chapter 5 to induce a change in morphology and an increase in motility of endothelial cells. The alterations in the endothelial surface of blood vessels induced by lymphokines, released during rejection of an allograft, could affect the blood flow along these surfaces of endothelium. Lymphokines would in that case be responsible for a disturbed circulation in the allograft, leading to a decrease in function. These suggested effects of lymphokines on blood flow in transplanted organs will be subject of further investigations.

An other effect of lymphokines on endothelial cells is induction of expression of MHC-antigens, described in chapter 9. Lymphokines increase the expression of MHC-class II antigens on endothelial cells, both from arterial and venous origin. The expression of these antigens can have several effects. The MHC-class II antigens can serve as target determinants for CTL $(11,12,13)$; increased expression of the target determinants will make the cells more susceptible for lysis by CTL. The expression of MHC-class II antigens will result in amplification of immune responses. Helper $\mathrm{T}$ lymphocytes are restricted for their activation to MHC-class II antigens. The result of antigen expression will be increased secretion of lymphokines, mediators of DTH-reaction, and increased proliferation of CTL, caused by $\mathrm{T}$ helper cell produced 11-2. 
Cyclosporin A affects MHC-class II antigen expression by endothelial cells. CyA inhibits the production of lymphokines responsible for antigen expression (14) by both resting and activated lymphocytes and does not have an effect on the expression of MHC-class II antigens in the presence of lymphokines. The immunosuppressive effect of CyA can be explained in part by the influence on MHC-class II antigen expression since absence of MHC-class II antigens prevents activation of lymphocytes and amplification of immune responses. The inhibited secretion of lymphokines responsible for induction of $\mathrm{MHC}$-class II antigen expression, without effect of CyA on the expression of antigens per se, permits study of regulation of MHC-class II antigen expression on endothelial cells in vivo. Decrease in endothelial MHC-class II antigen expression in dogs given CyA to inhibit lymphokine production, demonstrates that this antigen expression is not a constitutive property of endothelial cells and must be dependent on products, whose production is inhibited by CyA in vivo. The experiments suggest reduction of MHC-class II antigen expression on endothelium by CyA to be a mode of action by CyA in prolongation of renal allograft survival.

Endothelial cells are a target for cell-mediated cytotoxicity by CTL (chapter 3). Lysed endothelial cells are known to result in activation of the coagulation cascade (unpublished observation), which could be part of the rejection process. The factors involved in the interaction of endothelial cells and the coagulation cascade are subject of further study.

The determinants recognized by CTL on endothelial cells have been studied with a cold-target inhibition technique (chapter 3 ) and by clonal expansion of CTL (chapter 4). Cold target inhibition of CTL generated in MLC demonstrates a difference in determinants recognized on AEC and VEC, compared to lymphoblasts. Clonal expansion of MLC-generated CTL suggests that a number of alloantigen systems are present on target cells with a wide or with a limited distribution over these target cells. The different alloantigen systems are also suggested by the cell-mediated cytotoxicity patterns of CTL stimulated by AEC and by VEC. The distribution of these alloantigen systems sets limits to the value of donor-recipient matching in clinical transplantation based on study of blood cells as lymphocytes and monocytes only. The specificity of cloned CTL, generated against allogeneic endothelial cells might clarify antigen systems expressed on endothelial cells. It is likely that the alloantigen systems with limited distribution have a function in discrimination at the tissue level between self and non-self. This function would make these alloantigen systems relevant in organ transplantation. Future studies will be directed to analyse the alloantigens of endothelial cells.

The role and function of endothelial cells in immunological reactions have been found to exist at several levels in the chain of events. In brief, both in wivo and in vitro endothelial cells can express MHC-class II antigens under the influence of lymphokines. Therefore endothelial cells can function in the regulation of immunological processes. Endothelial cells from arterial and venous origin stimulate lymphocytes via self-alloantigen presentation. The activated lymphocytes produce 
lymphokines that change the morphology and increase the motility of endothelial cells. Endothelial cells are lysed by CTL. These CTL recognize different determinants on $A E C$ and VEC, which is extended by the observation that cloned CTL define alloantigen systems with limited tissue distribution. In conclusion: endothelial cells can have essential functions in immunological reactions leading to allograft rejection.

\section{Literature cited}

1. Burman WA, Vegr PA, v.d. Linden CJ, Greep $3 \mathrm{M}$.

Celutar cytotoxicity generated in a canine mixed kidney lymphocyte cell culure.

Tissue Antigens $1981 ; 18: 326$.

2. Vegt PA, y.d. Linden CJ, Daenen AJMM, Jeekel J. Buurman WA.

Lymphocyte stimulation by canke kidney cells.

Transplantation 1982; $34: 134$.

3. Main $\mathrm{RK}_{\mathrm{y}}$ Jones M. Birnbaum $\mathrm{Y}$, Kountz SL.

Mixed cufure response of lymphocytes to dissociated kidney cells.

Transplantation $1975 ; 20: 92$.

4. Mashimo S, Sakai A, Ochiai T, Koumz SL.

The mixed kidney cell-lymphocyte reaction in rats.

Tissue Antigens 1976; 7:291.

5. Levis WR, Miller AE.

Leucocyte-skin cultures as a meastre of histocompatiblity in man.

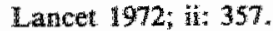

6. Cochrum KC, Main RK, Kountz SL.

A new rnatching technique: The mixed skin cell-feukocyte reaction (MSLR).

Surgery $1971 ; 70: 97$.

7. Tanaka S, Sakai A.

Stimulation of allogeneic lymphocytes by skin epidermal cells int the rat.

Transplantation $1979 ; 27: 194$.

8. Steinmulter $D$, Wunderlich IR.

The use of freshly explanted moxse epidermat cells for the in vitro induction and detection of cellmediated cytotoxicity.

Cell Immunol 1976; 24: 146.

9. Hirschberg $H$, Evensen SA, Hendriksen T, Thorsby $\mathrm{E}$.

Stimulation of human lymphocytes by allogeneic endothellat cells in vitro.

Tissue Antigens 1974; 4: 257.

10. Vetto RM, Burger DR.

Endothelial cell stimulation of allogeneic lymphocytes.

Transplantation $1972 ; 14: 652$.

11. Feighery $C$, Stastny $P$.

HLA-D region associated determinants serve as targets for human cell-mediated lysis.

I Exp Med 1979: 149: 485.

12. Johnison HE, Mossin $J$, Madsen M, Kristensen $T$, Kismeyer-Nielsen F.

Human B-blast specific target determinants in CML: a family study.

Tissue Antigens 1982; 19: 222 .

13. Johnsen HE.

Human B-blast specific target determinants in CMC: a methodological study.

Tissue Antigens 1980; 15: 189.

14. Reem GH, Cook LA, Vicek $I$.

Gamma interferon synthesis by human thymocytes and $T$ lymphocytes is inhibited by cyclosporin $A$.

Science 1983; 221: 63. 



\section{CHAPTER 12A}

\section{Summary}

This thesis presents the results of a study on the role and function of vascular endothelial cells in immune responses.

In section 'Introduction' an overview of immune reactions involved in allograft rejection is presented. The succeeding events in immune processes can be described as follows: Antigen is taken up by antigen presenting cells, processed in these cells, and expressed on the cell membrane in association with MHC-class II antigens. Helper T lymphocytes recognize the complex of antigen and MHC-class II antigens and are activated by the APC-released II-1. T helper cells release lymphokines, among them II-2, after activation. Precursors of cytotoxic T lymphocytes recognize antigen in association with MHC-class I antigen and are activated by Il-1. Upon activation, the CTL acquire receptors for the T cell growth factor II-2 and start to proliferate to achieve expansion of the effector cell population. A different mode of $T$ cell activation occurs in allograft reactions. In an allograft specialized cells from the donor present their own alloantigens to $\mathbb{T}$ lymphocytes of the recipient, which are thereby activated.

In section 'Introduction to the experiments', it is indicated in which events the putative role and function of endothelial cells have been studied.

Chapter 3 describes the technique of culture of endothelial cells in vitro. The target determinants recognized by CTL, generated in MLC, on arterial and venous endothelial cells and lymphoblasts are compared in cold target inhibition experiments. It is concluded that these CTL recognize similar determinants on AEC and lymphoblasts, and different determinants on VEC and lymphoblasts.

Chapter 4 describes a procedure for cloning of canine CTL, generated in mixed lymphocyte cultures. The patterns of cytolysis of lymphoblasts, monocytes and AEC and VEC have been determined. A limited number of patterns of lysis of one or more than one of these four different targets has been observed. These data suggest the existence of a number of alloantigen systems with a wide or with a limited distribution ower the used target cells.

Chapter 5 describes the effects of lymphokines on the morphology and motility of endothelial cells. In a species specific action lymphokines other than Interleukin 2 and interferon gamma affect the morphology of canine and human endothelial cells and increase their motility.

Chapter 6 describes the stimulation of lymphocytes by allogeneic endothelial cells. It is observed that allogeneic endothelial cells induce proliferation of lymphocytes. AEC generate CTL against AEC and lymphoblasts, while VEC generate CTL against AEC, VEC and lymphoblasts. It is concluded, in relation to the finding in chapter 3, that different determinants are recognized on AEC and VEC, in both the generation phase and in the effector phase of cell-mediated cytotoxicity. 
Chapter 7 describes a method to deplete suspensions of canine peripheral blood leukocytes of antigen presenting cells, and thereby isolate purified populations of lymphocytes. This method is used to study the capacity of endothelial cells to present alloantigens to unprimed syngeneic lymphocytes in support of proliferation of these lymphocytes and of generation of CTL. It appears that both AEC and VEC can present alloantigens in this system, resulting in proliferation and differentiation of lymphocytes in MLC. Endothelial cells of the recipient would therefore be able to present donor alloantigens shed from an allograft to recipient lymphocytes.

Chapter 8 describes experiments to study the capacity of endothelial cells to stimulate allogeneic lymphocytes without the need for additional antigen presenting cells. The experiments indicate that venous endothelial cells are capable of self-alloantigen presentation. It is concluded that donor endothelial cells can be important in the initial phase of rejection of vascularized allografts because of their capacity to present donor self-alloantigens to recipient lymphocytes.

Chapter 9 and 10 describe the expression of MHC-class II antigens by endothelial cells. Lymphokines were observed to induce the expression of these antigens in vitro. The secretion of these lymphokines is inhibited by cyclosporin A (chapter 9). The expression of MHC-class II antigens on endothelial cells in vivo is absent during treatment of dogs with cyclosporin $A$ in vivo. It is concluded in chapter 10 that the antigen expression by endothelial cells is not a constitutive property of these cells, but is dependent on lymphokines.

In section 'General discussion of the experiments' an overview is presented of the roles and functions of endothelial cells in immune reactions that have been studied. MHC-class II antigen expression in vitro and in vivo, both dependent on lymphokines, allow a regulatory function in immunological processes. Endothelial cells stimulate the generation of CTL. CTL recognize different determinants on AEC and VEC, demonstrated at the clonal level of CTL. Endothelial cells are lysed by CTL and affected by lymphokines. In conclusion: endothelial cells have essential functions in immunological reactions leading to allograft rejection. 


\section{HOOFDSTUK 12B}

\section{Samenvatting}

In dit proefschrift worden de resultaten gepresenteerd van een onderzoek naar de rol en functie van vasculaire endotheelcellen in immunologische reacties.

In 'Introduction" wordt een overzicht gegeven van immunologische reacties die betrokken zijn bij afstoting van getransplanteerde organen. De opeenvolgende gebeurtenissen daarbij worden beschreven: antigeen wordt opgenomen door een antigeen presenterende cel, in deze cel verwerkt en daarna op de celmembraan gepresenteerd in samenhang met MHC-klasse II antigenen. T-lymfocyten met hulp-functie herkennen dit complex van antigeen en MHC-class II antigeen en worden geactiveerd door I1-1 wat vrijgemaakt wordt door de antigeen presenterende cellen. Hulp T-cellen scheiden na activatie lymfokinen, waaronder II-2, uit. Voorlopers van cytotoxische T-lymfocyten herkennen het antigeen in samenhang met MHC-klasse I antigenen en worden geactiveerd door $11-1$. Tijdens activatie krijgen CTL receptoren voor de Tcel groeifactor 11-2 en door proliferatie wordt de effector cel populatie vergroot. Tijdens reacties tegen een transplantaat worden $T$ lymfocyten op een andere wijze geactiveerd: in een transplantaat presenteren gespecialiseerde cellen hun eigen lichaamsvreemde antigeen aan $\mathrm{T}$ lymfocyten van de transplantaat-ontvanger, waardoor de $T$ lymfocyten geactiveerd worden.

In 'Introduction to the experiments' is aangegeven in welke gebeurtenissen de mogelijke rol en functie van endotheelcellen is bestudeerd.

'Chapter 3' beschrijft de techniek van het kweken van endotheelcellen in vitro. In 'cold target inhibition' experimenten worden de determinanten die in MLC gegenereerde CTL herkennen op arteriële en veneuze endotheelcellen en lymfoblasten vergeleken. De uitkomsten van de experimenten geven aan dat CTL gelijke determinanten herkennen op AEC en lymfoblasten en verschillende determinanten op VEC en lymfoblasten.

'Chapter 4' beschrijft een methode voor het kloneren van CTL wit MLC van de hond. De patronen van cytolysis van $\$ ymfoblasten, monocyten, AEC en VEC werden bepaald. Een beperkt aantal patronen van lysis van een of meer verschillende cellen werd waargenomen. De uitkomsten suggereren het bestaan van een aantal systemen van lichaamsvreemde antigenen met een beperkte of met een ruime verspreiding over de gebruikte cellen.

'Chapter 5 ' beschrijft het effect van lymfokinen op de vorm en beweeglijkheid van endotheelcellen. Lymfokinen anders dan Il-2 en gamma interferon veroorzaken op een species-specifieke wijze verandering in de vorm van de endotheelcellen van mens en hond en een verhoogde beweeglijkheid van deze cellen.

'Chapter 6' beschrijft de stimulatie van lymfocyten door lichaamsvreemde endotheelcellen: deze endotheelcellen veroorzaken proliferatie van lymfocyten. AEC ge- 
nereerden CTL tegen AEC en lymfoblasten, terwijl VEC CTL genereerden tegen AEC, VEC en lymfoblasten.

'Chapter 7 ' beschrijft een methode om antigeen presenterende cellen te verwijderen uit een suspensie van witte bloedcellen van de hond ter bereiding van gezuiverde lymfocyten. Met behulp van deze methode kon bestudeerd worden of endotheelcellen in staat zijn lichaamsvreemd antigeen te presenteren aan lymfocyten ter ondersteuning van proliferatie en differentiatie tot CTL. Het bleek dat zowel AEC als VEC lichaamsvreemd antigeen kunnen presenteren aan gezuiverde lymfocyten, die daardoor kunnen prolifereren en differentiëren in MLC. Endotheelcellen van de ontvanger zouden daarmee in staat zijn donor antigenen, losgelaten uit een transplantaat, te presenteren aan lymfocyten van de ontvanger van het transplantaat. 'Chapter $8^{*}$ beschrijft een studie naar de mogelijkheid van endotheelcellen tot lymfocytenstimulatie, onafhankelijk van andere antigeen presenterende cellen. De experimenten laten zien dat donor endotheelcellen in staat zijn tot presentatie van donoreigen lichaamsvreemde antigenen aan lymfocyten van een ontvanger van een transplantaat. Dit maakt dat endotheelcellen een belangrijke rol kunnen spelen in de in:tiële fase van de afstoting van gevasculariseerde transplantaten.

'Chapter 9 en 10' beschrijven de expressie van MHC-klasse II antigenen op endotheelcellen. Lymfokinen induceren de antigeenexpressie in vitro, waarbij blijkt dat cyclosporine A de produktie van de relevante lymfokinen remt (chapter 9). De expressie van MHC-klasse II antigenen op endotheel in vivo is afwezig tijdens behandeling van honden met CyA. Daarom kan gesteld worden dat de expressie geen onveranderlijke eigenschap is van endotheel, maar afhankelijk is van lymfokinen.

In 'General discussion of the experiments' wordt een overzicht gegeven van de bestudeerde rollen en functies van endotheel in immunologische reacties. Zowel in vivo als in vitro is endotheel in staat tot expressie van MHC-klasse II antigenen onder invloed van lymfokinen. Hierdoor kunnen endotheelcellen een rol hebben in de regulatie van immunologische processen. Endotheelcellen kunnen CTL genereren door lymfocyten stimulatie. CTL herkennen verschillende antigenen op AEC en VEC, wat op klonaal niveau van de CTL zichtbaar is. Na herkenning worden endotheelcellen gelyseerd door CTL. Endotheelcellen worden beïnvloed door lymfokinen. Uit bovenstaande volgt dat endotheelcellen essentiële functies hebben in de immunologische reacties die leiden tot afstoting van transplantaten. 



\section{List of publications presented in this thesis}

Groenewegen G, Buurman WA, van der Linden CJ, Jeunhomme GMAA, Kootstra G.

Cellular cytotoxicity against canine endothelial cells. Analysis of determinants recognized by CTL.

Tissue Antigens 1983; 21: 114.

part of this work was published in:

Groenewegen G, Buurman WA, Jeunhomme GMAA, Kootstra G.

Cell-mediated cytotoxicity targets on canine endothelial cells.

Transplant Proc 1983; 15: 289.

Groenewegen G, Buurman WA, van der Linden CJ, Jeunhomme GMAA, Kootstra G.

Cell-mediated cytotoxicity patterns of cloned cytotoxic T lymphocytes. Cytotoxicity directed against lymphoblasts, monocytes and endothelial cells.

Transplantation 1985; in press.

Groenewegen $G$, Buurman WA, van der Linden CJ.

Lymphokines induce change in morphology and enhance motility of endothelial cells.

Clin Immunol Immunopathol 1985; in press.

Groenewegen G, Buurman WA, Jeunhomme GMAA, van der Linden CJ, Vegt PA, Kootstra G.

In vitro stimulation of lymphocytes by vascular endotheliall cells. A study with canine arterial and venous endothelial cells.

Transplantation 1984; 37: 206.

Groenewegen G, Buurman WA.

Vascular endothelial cells present alloantigens to unprimed lymphocytes.

Scand J Immunol 1984; 19: 269.

Groenewegen G, Buurman WA., Jeunhomme GMAA.

Self-alloantigen presentation by canine endothelial cells in vitro.

Submitted for publication. 
Groenewegen G, Buurman WA, Jeunhomme GMAA, van der Linden CJ. Cyclosporin A affects MHC-class II antigen expression by arterial and venous endothelium in vitro.

Transplantation 1985; in press.

part of this work was published in:

Groenewegen G, Buurman WA, Jeunhomme GMAA.

Class II expression by endothelial cells is affected by cyclosporin A.

Transplant Proc 1985; 17: 1417.

Groenewegen G, Buurman WA, van der Linden CJ.

In vivo expression of MHC-class II antigens by endothelium is lymphokine dependent.

Nature 1985; in press. 
De experimenten, beschreven in dit proefschrift, werden verricht in dienst van de capaciteitsgroep Algemene Heelkunde (voorzitter Prof. Dr. J.M. Greep). Het experimentele werk vond plaats in het laboratorium van de Heelkunde (Biomedisch Centrum). De Nier Stichting Nederland verleende financiële ondersteuning voor de uitvoering van het project 'Cellulaire immuunreakties in vitro tegen in de nier voorkomende cellen' (C 81.297), waaruit dit proefschrift voortgekomen is.

Prof. Dr. G. Kootstra was verantwoordelijk voor aanstelling bij deze groep en hield daarna een aangenaam werkklimaat in stand. Dr. W.A. Buurman, hoofd van het laboratorium, verzorgde op stimulerende wijze de introduktie in het onderzoekersvak en in het onderzoeksgebied en droeg daardoor in hoge mate bij aan dit proefschrift. Mevrouw G.M.A.A. Jeunhomme verrichtte met grote zorgvuldigheid het merendeel van het experimentele werk. Mevrouw A.J.J.M. Daemen en mevrouw E.E.M. Spronken waren behulpzaam met hun vaardigheden en kennis als daarop een beroep gedaan werd. Dr. C.J. van der Linden droeg bij aan verslaglegging en inhoud van de experimenten. Mevrouw K. Spronck bleef bereid om nieuwe versies van de publicaties in de computer te stoppen en als proefschrift klaar te maken. Mevrouw P. Rommers en de heren $H$. Simons en M. Bost gaven de honden in experiment de noodzakelijke zorg en aandacht. Dr. P.A. Vegt, Drs. T.J.M. Ruers en Drs. R.F.C. Doveren droegen als collegae door hun belangstelling bij aan dit proefschrift.

Beste Gauke, Wim, Trudi, Ineke, Ilse, Cees, Karin, Petra, Huub, May, Paul, Theo, Rob en Inge, bedankt voor jullie bijdragen aan mijn proefschrift. 
De auteur van dit proefschrift werd geboren op 9 november 1955 in Eindhoven. Het vwo-diploma (Atheneum B) werd behaald in 1974 aan het Lorentz Lyceum in Eindhoven. In dat zelfde jaar werd de studie geneeskunde begonnen aan de Medische Faculteit van de Erasmus Universiteit Rotterdam. Het doctoraalexamen werd behaald in 1979 en het artsexamen in 1981. Vanaf 1 april 1981 tot heden werd gewerkt aan dit proefschrift (Medische Faculteit, Rijksuniversiteit Limburg, Maastricht). Na de promotie zal, nog steeds in Maastricht, gewerkt worden aan een voortzetting van het gepresenteerde onderzoek. 